\title{
EFEITOS DA IRRADIAÇÃO E REFRIGERAÇÃO NA QUALIDADE E NO VALOR NUTRITIVO DA TILÁPIA (Oreochromis niloticus)
}

\section{ALESSANDRA APARECIDA ZILIO COZZO DE SIQUEIRA}

\begin{abstract}
Dissertação apresentada à Escola Superior de Agricultura "Luiz de Queiroz", Universidade de São Paulo, para obtenção do título de Mestre em Ciências, Área de concentração: Ciência e Tecnologia de Alimentos.
\end{abstract}

\section{PIRACICABA}

Estado de São Paulo - Brasil

Outubro - 2001 


\section{EFEITOS DA IRRADIAÇÃO E REFRIGERAÇÃO NA QUALIDADE E NO VALOR NUTRITIVO DA TILÁPIA (Oreochromis niloticus)}

ALESSANDRA APARECIDA ZILIO COZZO DE SIQUEIRA

Nutricionista

Orientadora: Prof. ${ }^{a}$ Dr.a MARÍLIA OETTERER

Dissertação apresentada à Escola Superior de Agricultura "Luiz de Queiroz", Universidade de São Paulo, para obtenção do título de Mestre em Ciências, Área de concentração: Ciência e Tecnologia de Alimentos.

\section{PIRACICABA}

Estado de São Paulo - Brasil

Outubro - 2001 
Dados Internacionais de Catalogação na Publicação (CIP) DIVISÃO DE BIBLIOTECA E DOCUMENTAÇÃO - ESALQ/USP

Siqueira, Alessandra Aparecida Zilio Cozzo de

Efeitos da irradiação e refrigeração na qualidade e no valor nutritivo da Tilápia (Oreochromis niloticus) / Alessandra Aparecida Zlio Cozzo de Siqueira. - -

Piracicaba, 2001.

137 p. : il.

Dissertação (mestrado) - - Escola Superior de Agricultura Luiz de Queiroz, 2001.

Bibliografia.

1. Alimento processado 2. Conservação de alimento por irradiação 3. Conservação alimento processado 4. Tecnologia de alimento 5. Tilápia 6 . Valor nutritivo I. Título

CDD 664.94

"Permitida a cópia total ou parcial deste documento, desde que citada a fonte - $\mathrm{O}$ autor" 
Dedico ao meu marido, pelo incentivo, compreensão e carinho. A minha família, pelo apoio, auxílio espiritual e entendimento. E a Deus Pela vida e oportunidade de crescer. 


\section{AGRADECIMENTOS}

À minha família e, principalmente ao meu marido Rogério Durvalino de Siqueira pelo apoio e compreensão;

Aos meus pais Antonio João Cozzo e Marlene Apparecida Zilio Cozzo, e também ao meu irmão Alexandre Antonio Zilio Cozzo pelo incentivo, apoio emocional e auxílio espiritual;

À minha orientadora Dra. Marília Oetterer, pelo incentivo emocional, amizade e dedicação durante toda a realização do curso de mestrado e elaboração do trabalho da dissertação;

À Escola Supeiror de Agricultura “Luiz de Queiroz”- Universidade de São Paulo - Departamento de Agroindústria, Alimentos e Nutrição pela disponibilidade dos laboratórios para o desenvolvimento das pesquisas;

Á Fundação de Apoio à Pesquisa do Estado de São Paulo (FAPESP) pela bolsa de mestrado e financiamento da pesquisa;

Ao Centro de Energia Nuclear na Agricultura (CENA) pela permissão de uso da fonte de Cobalto GammaBean para irradiação das amostras;

À Dra. Rachel E. Domarco pela colaboração na condução da irradiação das amostras; 
Ao Instituto de Tecnologia de Alimentos (ITAL) Campinas, pelas análises realizadas;

Ao Prof. Dr. Cláudio Rosa Gallo pela colaboração e auxílio na elaboração da análise microbiológica;

À Dra. Marta Helena Fillet Spoto pela colaboração, amizade e auxílio na elaboração da análise sensorial;

À Profa. Dra. Marisa A.B. Regitano d'Arce pelo incentivo, amizade e sugestões;

Aos funcionários do Departamento de Agroindústria, Alimentos e Nutrição especialmente às técnicas do Setor de Processamento de Alimentos - Laboratório de Pescado, Ivani Marchetto Moreno, Roberta Rizzo Benato e Juliana Antunes Galvão;

Às bibliotecárias Beatriz Helena Giongo e Midiam Gustinelli pela correção das referências bibliográficas;

A todos os participantes da análise sensorial;

E a todos que contribuíram direta ou indiretamente para a execução deste trabalho. 


\section{SUMÁRIO}

Página

LISTA DE FIGURAS..................................................................... viii

LISTA DE TABELAS......................................................................

RESUMO .................................................................................. xii

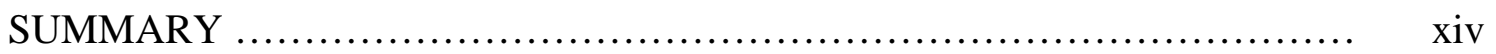

1 INTRODUÇÃ

2 REVISÃO DE LITERATURA …......................................................... 7

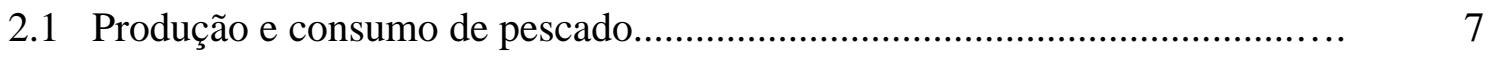

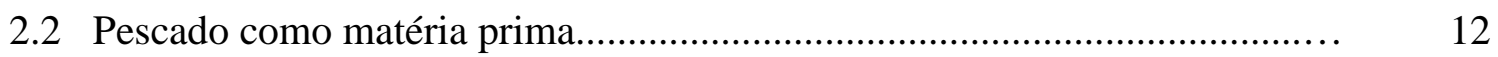

2.3 Processamento do pescado refrigerado..................................................... 20

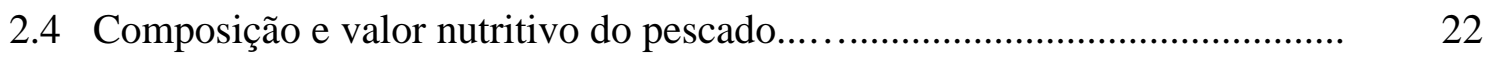

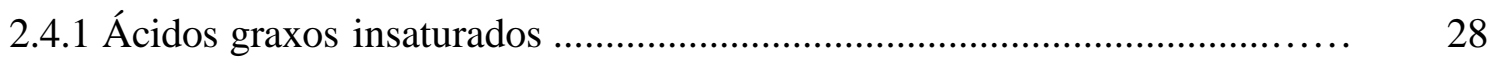

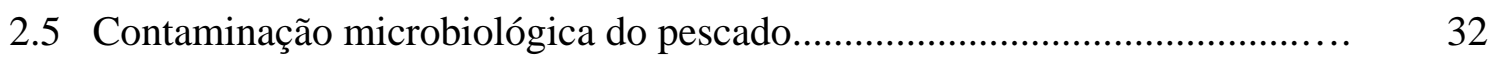

2.6 Efeito das radiações ionizantes nos alimentos......................................... 34

2.6.1 Efeito das radiações sobre os microrganismos....................................... 41

2.6.2 Aplicações das irradiações em alimentos............................................... 48

2.7 Propriedades sensoriais dos alimentos............................................... 51 
3 MATERIAL E MÉTODOS _.................................................................. 54

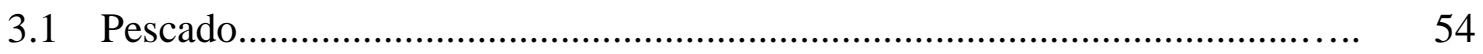

3.2 Beneficiamento da matéria-prima................................................................ 54

3.3 Irradiação do pescado............................................................................ 56

3.4 Refrigeração do pescado.......................................................................... 58

$3.5 \quad$ Análises microbiológicas........................................................................... 59

3.6 Análises físico-químicas e nutricionais .............................................................. 60

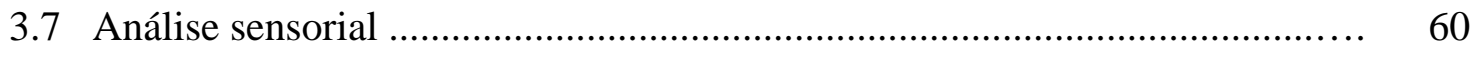

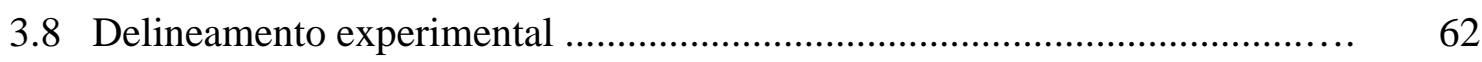

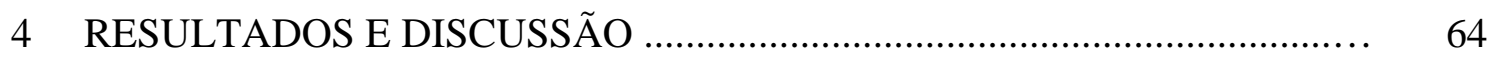

4.1 Composição centesimal ............................................................................ 64

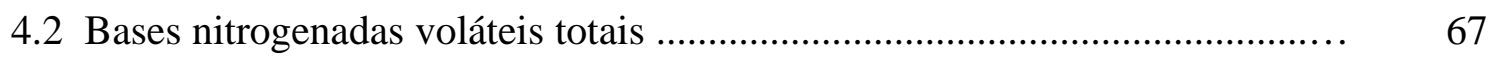

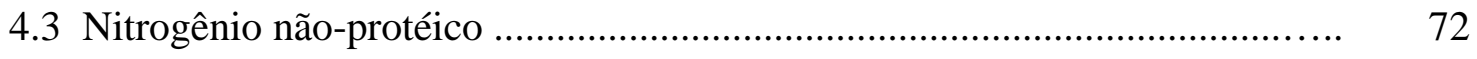

$4.4 \mathrm{pH}$

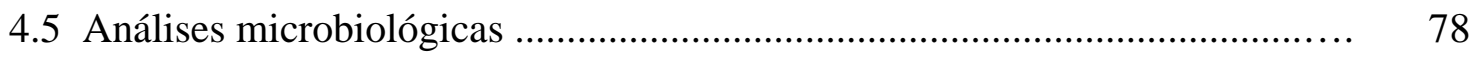

4.6 Substâncias reativas ao ácido tiobarbitúrico (TBARS) ..................................... 83

4.7 Análises nutricionais ............................................................................. 88

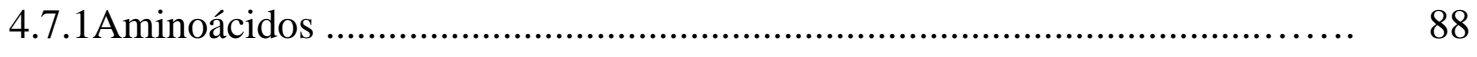

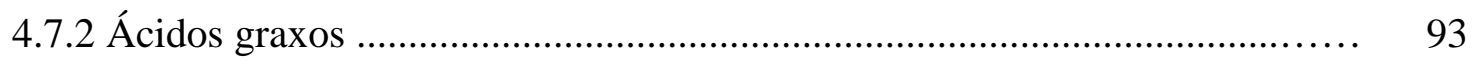

4.7.3 Vitamina B1 (tiamina) e vitamina A .......................................................... 96

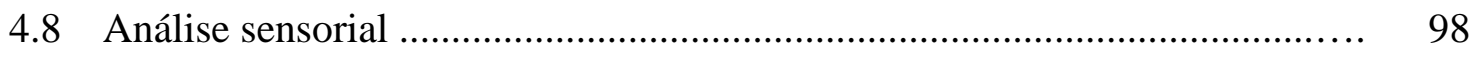




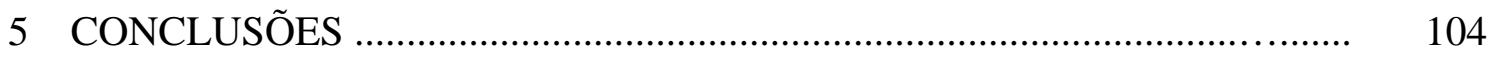

REFERÊNCIAS BIBLIOGRÁFICAS............................................................. 106

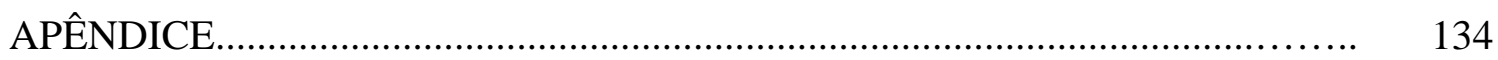




\section{LISTA DE FIGURAS}

Página

1 Símbolo Radura .......................................................................................... 38

2 Limpeza e manipulação do peixe .................................................................... 55

3 Postas de peixe armazenadas em recipiente tipo "placas de Petri” para posterior irradiação e armazenamento refrigerado ........................................................ 55

4 Filés de tilápia dispostos em bandejas de isopor para posterior irradiação e

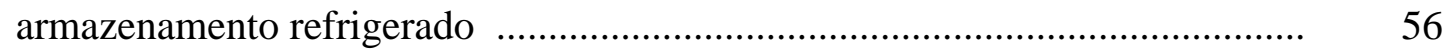

5 Fonte de cobalto-60, modelo Gammabean 650 da Nordion, Otawa/Canadá, utilizada

para a irradiação das amostras de pescado..................................................... 57

6 Armazenamento refrigerado .................................................................... 58

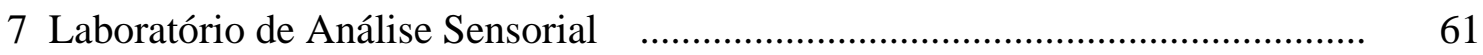

8 Bases nitrogenadas voláteis totais, em matéria úmida, do pescado não irradiado e irradiado, segundo o tempo de armazenamento ............................................. 68

9 Nitrogênio não protéico do pescado não irradiado e irradiado em matéria seca, segundo o tempo de armazenamento .......................................................... 73

10 Valores de $\mathrm{pH}$ do pescado não irradiado e irradiado, segundo o tempo de armazenamento 75 
11 Valores de TBARS do pescado não irradiado e irradiado em matéria úmida, segundo o tempo de armazenamento ........................................................................ 84 


\section{LISTA DE TABELAS}

Páginas

1 Componentes nitrogenados em músculo de peixes brasileiros de água doce........ 19

2 Necessidades diárias de aminoácidos essenciais e conteúdo destes no

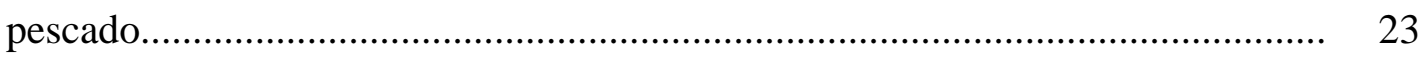

3 Ácidos graxos $(\mathrm{g} / 100 \mathrm{~g})$ constituintes de partes comestíveis de peixes

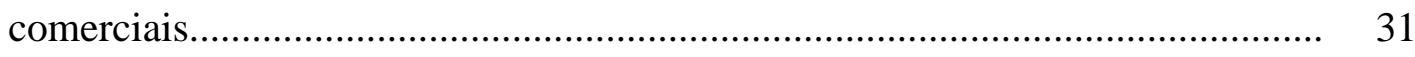

4 Composição centesimal (g/100g de matéria seca) do peixe não irradiado e irradiado, segundo o tempo de armazenamento ........................................................ 64

5 Coliformes totais em pescado não irradiado e irradiado, segundo os períodos de armazenamento sob refrigeração

79

6 E. coli em pescado não irradiado e irradiado, segundo os períodos de armazenamento sob refrigeração

7 Microrganismos psicrotrófilos nas amostras de pescado não irradiado e irradiado, segundo os períodos de armazenamento sob refrigeração …............................ 80

8 Aminoácidos (mg/100g em matéria seca) do peixe não irradiado e irradiado, segundo o tempo de armazenamento (inicial e 20 dias) 
9 Ácidos graxos do pescado não irradiado e irradiados armazenados sob refrigeração

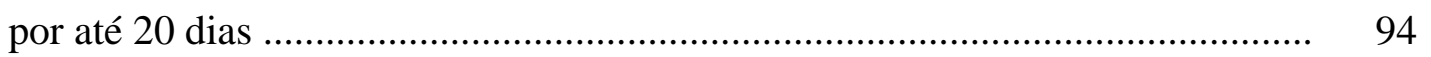

10 Vitamina B1 (em mg/100g), retinol (em mcg/100g) e vitamina A (em UI/100g) no pescado não irradiado e irradiado armazenados sob refrigeração por 20

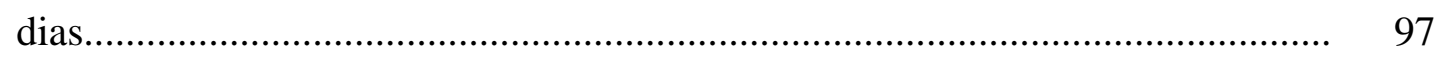

11 Médias de doses para o teste hedônico de aparência e aroma do pescado não irradiado e irradiado armazenado sob refrigeração................................................................. 99 


\title{
EFEITOS DA IRRADIAÇÃO E REFRIGERAÇÃO NA QUALIDADE E NO VALOR NUTRITIVO DA TILÁPIA (Oreochromis niloticus)
}

\author{
Autora: ALESSANDRA APARECIDA ZILIO COZZO DE SIQUEIRA \\ Orientadora: Prof ${ }^{\mathrm{a}}$. Dra ${ }^{\mathrm{a}}$. MARÍLIA OETTERER
}

\section{RESUMO}

Esta pesquisa teve por objetivo prolongar o tempo de vida comercial do pescado beneficiado, através da utilização das radiações ionizantes, associadas às técnicas complementares de refrigeração, sob a ótica do alimento minimamente processado. Analisou-se os aspectos físicos, químicos, nutricionais e microbiológicos de tilápias da espécie nilótica (Oreochromis niloticus) evisceradas e em cortes comerciais, separadas em amostras irradiadas com 1; 2,2 e 5 kGy e não irradiadas, armazenadas sob refrigeração na faixa de 0,5 a $-2^{\circ} \mathrm{C}$, durante 20 e 30 dias. Notou-se que a umidade nas amostras não irradiadas diminuiu, com conseqüentes alterações nos teores de proteína e lipídeos, que aumentaram nos períodos de análise; já as amostras irradiadas mantiveramse estáveis. $\mathrm{O}$ pH foi um indicativo importante para a determinação do frescor do peixe, 
associado ao índice de bases nitrogenadas voláteis totais (BNVT) e ao nitrogênio nãoprotéico (NNP) os quais, mostraram-se crescentes para as amostras não irradiadas; enquanto que para as irradiadas mantiveram-se estáveis. $\mathrm{O}$ acompanhamento microbiológico para coliformes totais e fecais durante o período de armazenamento, permitiu verificar a eficácia da irradiação, uma vez que, as amostras irradiadas apresentaram contagens microbiológicas abaixo dos valores mínimos estabelecidos pela legislação para pescado, fato que não ocorreu para as amostras não irradiadas. Salmonella e Staphylococcus aureus não foram detectados.

Analisaram-se os teores de aminoácidos, em matéria seca, e de ácidos graxos dos lipídeos extraídos das tilápias, notando-se estabilidade nas amostras irradiadas e decréscimo nos valores encontrados para as não irradiadas, nos períodos estudados. Determinaram-se também, substâncias reativas ao ácido tiobarbitúrico (TBARS) e os resultados mostraram tendência ao aumento conforme o aumento da dose de irradiação.

A boa aceitação para aparência, aroma, cor e textura obtida na análise sensorial dos produtos armazenados por um período de 30 dias, mostrou a viabilidade do processo combinado de irradiação e refrigeração quanto à intenção de estender a vida útil das tilápias submetidas ao processamento mínimo.

Palavras-chave: pescado cultivado, tilápia nilótica, tilápia minimamente processada, irradiação, refrigeração, bases nitrogenadas voláteis totais, nitrogênio não protéico. 


\title{
EFFECTS OF IRRADIATION AND REFRIGERATION ON THE NUTRIENTS AND SHELF-LIFE OF TILAPIA (Oreochromis niloticus)
}

\author{
Author: ALESSANDRA APARECIDA ZILIO COZZO DE SIQUEIRA \\ Adviser: Prof $^{\mathrm{a}}$. Dr ${ }^{\mathrm{a}}$. MARÍLIA OETTERER
}

\section{SUMMARY}

The objective of this study is to enhance the shelf-life of processed fish, combining ionizing radiation and refrigeration with minimal processing. The physical, chemical, nutritional and microbiological characteristics of the specie Tilapia nilotica (Oreochromis niloticus) were studied in eviscerated samples and in commercial cuts. The fish were separated into samples irradiated with 1.0, 2.2 and 5 kGy and nonirradiated samples. They were stored at temperatures ranging from $0.5^{\circ} \mathrm{C}$ to $-2^{\circ} \mathrm{C}$ for 20 and 30 days. During storage, the level of moisture in the non-irradiated samples decreased and the levels of protein and lipid increased while the irradiated samples remained stable. 
The levels of $\mathrm{pH}$, TVB-N and NPN increased in the non-irradiated samples but tended to remain stable in the irradiated fish samples. During storage, microbiological analyses for the presence of coliforms proved the efficiency of the irradiation process. The irradiated samples had a microbiological content below the levels established by the Brazilian seafood legislation, whereas the non-irradiated samples had a higher microbiological content and were not in conformity with the officially permitted levels. Salmonella spp. and Staphylococcus aureus were not detected. The levels of amino acids in muscles and fatty acids in oil remained stable in the irradiated fish stored samples but decreased in the non-irradiated ones. Lipid-oxidation, measured by the TBARS test, showed a tendency to increase when the dose of irradiation increased.

The storage products after 30 days showed good acceptability for sensorial parameters, aparance, odour, color and texture, so it is possible to increase the shelf life of a minimally processed tilapia using combined irradiation and refrigeration.

Key words: freshwater cultivated fish, fish shelf life, tilapia (Oreochromis niloticus), minimally processed tilapia, irradiation, refrigeration, total volatile basic nitrogen, nonprotein nitrogen. 


\section{INTRODUÇÃO}

As necessidades mundiais de alimentos foram aumentando e os problemas, advindos da demanda de estruturas adequadas de armazenamento e processamento, levaram à busca de novos métodos de preservação. Neste contexto, a irradiação é utilizada como um método de preservação dos alimentos, tanto in natura quanto como coadjuvante dos processados industriais (Villavicencio, 1998).

O aumento na prática da piscicultura para produção de pescado leva à possibilidade de aplicação de métodos mais eficientes e saudáveis de comercialização, trazendo confiança ao consumidor. Todavia, com a expansão do comércio internacional e inter-regional de gêneros alimentícios, os riscos de contaminação podem aumentar, se transportados por longas distâncias sem as devidas condições de armazenamento (Käferstein \& Abdussalam, 1999).

A produção mundial da aqüicultura para pescado, moluscos, crustáceos e algas marinhas, em 1985 foi de, aproximadamente, 11,7 milhões de toneladas. A piscicultura representou naquele ano $10 \%$ da produção mundial de pescado, sendo 44,5\% de peixes (carpas, tilápias, salmonídeos e catfishes), 26,5\% de moluscos (ostras, mexilhões e mariscos), 2,5\% de crustáceos (camarões) e 26,5\% de algas marinhas; deste total, 53\% 
foram obtidos em águas frias, $40 \%$ em água salgda e $7 \%$ em água saloba (Nash, 1988). Em 1997, a aqüicultura brasileira produziu 70.500 toneladas de pescado, o que corresponde a pouco mais de $0,2 \%$ das 36,5 milhões de toneladas mundiais produzidas, atualmente. É necessário, portanto, uma interferência nesta produção com uma visão agronegocial, o que criará condições competitivas para o Brasil em nível mundial (Madrid, 2000).

O Brasil ainda importa parte do pescado que consome, apesar da produção proveniente da aqüicultura nacional ter triplicado nos últimos anos, passando de 26,8 mil toneladas em 1992, para cerca de 80 mil em 1999. Todavia, é necessário que o país aprenda a "vender melhor seu peixe", no sentido próprio da expressão, sendo preciso, uma melhor campanha promocional do pescado nacional, utilizando todos os meios de comunicação (Medeiros et al., 2000).

Para tornar o Brasil um país mais ágil, o Governo brasileiro decidiu mudar a forma de planejar e executar as ações criando culturas gerenciais, com diretrizes estratégicas a fim de consolidar a estabilidade econômica com crescimento sustentável; promover o desenvolvimento gerando empregos e oportunidades de renda, entre outras medidas. Foi criado, portanto, o programa Avança Brasil, um plano plurianual previsto para o período de 2000 a 2003, do qual foram constituídos 365 programas prioritários, entre os quais encontrase o Desenvolvimento da Aqüicultura que consta de recursos orçamentários da ordem de 50 milhões de reais (Madrid, 2000).

Enquanto a demanda de produtos de pescado vem aumentando em todo mundo, em vista da conscientização do ótimo valor nutricional deste produto, a disponibilidade deste ao 
consumidor não acompanha tal crescimento. É necessário, portanto, a implementação de práticas de conservação e preparo destes gêneros, incluindo peixes de menor porte, o que promoverá a prática da piscicultura; são prioritários os esforços para melhorar a forma de abatimento, uma vez que, cerca de $25 \%$ do total de pescado capturado em todo mundo é descartado devido ao manuseio inadequado (Venugopal et al., 1999; Villavicencio, 1992).

A atenção dos consumidores está voltada aos alimentos de conveniência (inclusive embalagem e distribuição), aos atributos nutricionais, à extensão da vida útil e à segurança. Para atender a estas exigências, a agroindústria brasileira tem evoluído na base de assimilar os avanços conseguidos em sistemas agroindustriais mais desenvolvidos, via compra de patentes, por empresas nacionais ou na associação de empresas, via "joint venture" (Bliska, 1997).

Como em outras áreas produtivas novos materiais e tecnologias surgiram para propiciar o progresso tecnológico agroindustrial. Com a globalização, a conscientização do consumidor está mais voltada para os alimentos mais saudáveis, mais nutritivos e com aparência mais próxima aos naturais, ou seja, tecnologias que minimizem os efeitos indesejáveis das alterações físico-químicas ou microbiológicas nos alimentos e que garantam a segurança do alimento. É necessário, portanto, a utilização de processos de duração curta, de tal forma, que se exponha o mínimo possível o produto a condições adversas, como é o caso dos produtos minimamente processados (Vitali, 1997).

A irradiação de alimentos, uma tecnologia pioneira em alguns países, pode ser uma saída para aliviar muitos dos problemas de perdas de alimentos no mundo. A irradiação como método de conservação tem como objetivo reduzir as perdas devidas à decomposição e 
combater os microrganismos causadores de enfermidades provenientes do alimento (Loaharanu, 1994).

A irradiação de alimentos no Brasil foi aprovada pelo Decreto $\mathrm{n}^{\mathrm{o}}$. 7218/1973, do Ministério da Saúde. Alimentos irradiados são comercializados em 23 países em caráter regular, junto com seus similares, e têm tido de modo geral, boa aceitação por parte do consumidor (Bruhn \& Wood, 1996; Derr et al., 1995; Loaharanu, 1994; Urioste et al., 1990), sendo que nos últimos anos foram realizados testes de aceitação na Argentina, Bangladesh, Chile, China, Estados Unidos, Filipinas, França, Hungria, Indonésia, Israel, Polônia, Tailândia e Alemanha, todos com resultados favoráveis (Ehlermam et al., 1996; ICGFI/IAEA, 1991). A Comissão Nacional de Energia Nuclear (CNEN) conforme a resolução 05/1980, aprovou as normas de irradiação de alimentos, posteriormente regulamentadas pela portaria $\mathrm{n}^{\mathrm{o}} .9$ da Divisão Nacional de Vigilância Sanitária de Alimentos (DINAL), de 8 de março de 1985. Para produtos do pescado, as doses médias recomendadas são as de 1,0 kGy para filé de peixe e 2,2 kGy para peixe salgado e defumado. Como tratamento prévio, conjunto ou posterior à irradiação, a temperatura deve ser mantida a $3 \mathrm{C}$, inclusive no armazenamento (IRRADIAÇÃO..., 1983). De maneira global, as finalidades específicas da irradiação em alimentos são: inibição de brotamento, desinfestação, radurização (redução de microrganismos formadores de esporos), radicidação (redução da carga de microrganismos patogênicos não formadores de esporos) e radapertização ou esterilização comercial (Bombo et al., 1996).

Savitci et al. (1997) estudaram a viabilidade e a importância da instalação de uma unidade de irradiação comercial de alimentos no Estado de São Paulo, e afirmam que se trata 
de uma tecnologia com característica fundamental de ser de multi-uso, desde que sejam seguidas as especificações de uso, e de doses a serem empregadas, para cada tipo de produto alimentício. Vale ressaltar que a operacionalidade da tecnologia utilizada exigirá inclusive uma conscientização, junto aos consumidores dos produtos irradiados sobre as vantagens da irradiação, principalmente para a manutenção da qualidade do produto.

Para o pescado, o uso da irradiação ou pasteurização a frio deve permitir que se obtenha um produto minimamente processado, aumentando a vida útil sob refrigeração, o que se constitui em um meio para se levar ao consumidor o pescado no estado de "fresco", sem necessariamente sofrer processos tecnológicos radicais, a não ser a filetagem ou o corte em postas.

O objetivo desta pesquisa foi obter um produto, tipo alimento de conveniência, de tilápia minimamente processada, estendendo sua vida útil, em refrigeração combinando com irradiação. O acompanhamento da qualidade do produto armazenado foi feita pela análise dos componentes físico-químicos e avaliação sensorial, microbiológica e nutricional. Estes produtos, pela sua alta qualidade, poderão, eventualmente ser exportados com mercado garantido no exterior, que já consome grande volume de produtos irradiados; como consequiência, o piscicultor terá sua receita aumentada. Quanto a utilização de peixes cultivados e em condições controladas, haverá possibilidade de uma programação do abate, constituindo-se em uma vantagem em relação à pesca extrativa, além da despesca organizada, possibilitando a captura de peixes sem traumas físicos e com baixo nível de estresse. 
Por se tratar de processos combinados, o valor nutritivo do pescado e a qualidade higiênica devem ser mantidos, diferente do que ocorre em outros processamentos tradicionais, ou mesmo quando o pescado é comercializado no estado de fresco, sob a ação do gelo. 


\section{REVISÃO DE LITERATURA}

\subsection{Produção e consumo de pescado}

Grande parte da população padece, em sua alimentação, de carência aguda ou crônica de proteínas de origem animal. A população brasileira encontra-se dentro deste quadro, uma vez que, na década de 80 , o consumo médio de carne ao ano era de $25 \mathrm{~kg}$, correspondente à metade do recomendado pela Organização Mundial da Saúde. Este fato tem se agravado pelas elevadas taxas de crescimento populacional, o que tem levado à procura de novas formas de produção de alimentos. A piscicultura pode constituir uma fonte alternativa de produção de proteína animal, em larga escala e a baixo custo, pois o Brasil apresenta excelentes condições para aumentar a produção de pescado, o que contribuiria para a solução do problema de desnutrição. No entanto, os sistemas de cultivo, captura, manuseio, processamento e comercialização apresentam-se deficientes, o que contribui para o baixo consumo do pescado (Bard, 1980; Nagel, 1979).

Segundo Oetterer (1991) o baixo consumo ou o pequeno hábito do brasileiro em consumir pescado, está ligado à comercialização mal feita que já vem sendo praticada há vários anos. $\mathrm{O}$ produtor não tem incentivo para colocar no mercado um produto de 
melhor qualidade que será mais oneroso, e que precisará de propaganda para sua divulgação. O consumidor, por sua vez, não se empenha em exigir melhores condições de um produto já desacreditado no mercado.

Segundo Nicoluzzi (1993) o sul-americano tem pouco hábito de consumir peixes. Sua dieta baseia-se em produtos cárneos bovinos e no frango. Isto se deve às oportunidades comerciais brasileiras que estão ligadas diretamente à qualidade, padronização, entrega e preços; tais caracteres relacionam-se a qualidade do produto que chega ao mercado.

É necessário, portanto estudar os mecanismos de alterações do peixe após a captura, determinar a influência das condições de manuseio e conservação, na qualidade e estabilidade do peixe congelado e obter métodos analíticos objetivos de avaliação do frescor, que tenham estreita relação com a análise sensorial, a fim de garantir a qualidade dos produtos oferecidos à população (Mujica,1988).

O potencial pesqueiro do Brasil, estimado pela FAO, considerando a extensa costa marítima, os rios navegáveis, as represas hidrelétricas e os $20 \%$ do total de água mundial concentrados na região amazônica; está em torno de 4 milhões de toneladas. Com $7.367 \mathrm{~km}$, a costa brasileira apesar de extensa em termos absolutos, é pequena quando comparada à área total do país. Em relação à pesca, sua exploração é restrita, realizada de forma inadequada e explorativa. Segundo pesquisadores da Universidade do Rio Grande do Sul, a pesca excessiva vai, em poucos anos, levar à extinção espécies como a corvina e o camarão. $\mathrm{O}$ maior problema encontra-se na pesca descontrolada por parte das indústrias da pesca realizada mesmo em épocas impróprias (Montenegro, 1998). 
O Brasil tem um dos maiores espelhos d'água do mundo, com 550 mil hectares de reservatórios e 407 km de canais de irrigação, somente no Nordeste; com clima favorável, insumos disponíveis e grandes extensões de terras alagadas subaproveitadas (mais de 2 milhões de hectares), além de possuir um dos melhores ambientes para o desenvolvimento da aqüicultura no mundo. Entretanto, a participação da aqüicultura brasileira na produção mundial de pescado é modesta apesar de seu rápido crescimento (25\% em 1997, contra $10 \%$ em nível mundial) (Madrid, 2000; Montenegro, 1998).

A produção de pescado no Brasil vem crescendo sob o influxo da expansão da piscicultura de água doce e com o grande potencial de águas interiores; pode-se pensar no pescado não só como excelente fonte alimentar, mas também, como fonte de divisas para o país através da exportação (Oetterer, 1991).

A piscicultura pode ser definida como o cultivo racional de peixes que permite a produção de alimento de alto valor nutritivo a baixo custo, compreendendo particularmente, o controle do crescimento e da reprodução; é altamente rentável ao pequeno produtor rural, com resultados melhores do que a maioria das culturas tradicionais, o que leva os produtores a abandonar a lavoura para investir nesta prática. Assim, podem ser cultivadas várias espécies, que devem apresentar como características, condições de reprodução em cativeiro e aceitar alimentação artificial. O cultivo racional de peixes, comparativamente ao de outras espécies animais, apresenta diversos aspectos mais vantajosos, dentre os quais: o peixe produz mais proteína por quilo de alimento consumido, isto é, apresenta excelente conversão alimentar, como também alta produtividade, pois, peixes cultivados em sistemas adequados de produção 
ganham, aproximadamente, $0,75 \mathrm{~g}$ de peso por grama de alimento consumido, enquanto o frango converte cerca de $0,45 \mathrm{~g}$ de peso por grama de alimento consumido. Os peixes utilizam alimentos que outros animais não aproveitam de forma tão eficiente, como resíduos de origem animal ou vegetal, plâncton, dejetos de animais, estes de modo direto ou indireto. $\mathrm{O}$ cultivo de peixes pode utilizar economicamente recursos que a agricultura não aproveita, como as áreas estuarinas e regiões alagadiças portanto, através da policultura, todos os níveis da cadeia alimentar são preenchidos, em razão da consorciação de espécies de hábitos alimentares complementares não concorrentes (Marchi, 1997; Medeiros et al., 2000).

Medeiros et al. (2000) afirmam que na piscicultura, em uma área de baixa produtividade é possível obter 4 toneladas de peixe por hectare, e consequente renda de mais ou menos R \$ 4 mil. Já em uma área de boa produtividade obtém-se até 10 toneladas, ou R\$ 10 mil, em média.

Segundo informações pessoais do Dr. José Eurico Cyrino (ESALQ/USP), a tilápia-

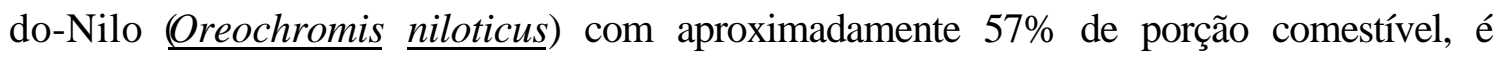
atualmente, a espécie de maior volume de produção da piscicultura, com produção estável e aceitação por parte do consumidor, inclusive vem sendo comercializada nos Estados Unidos na forma de filés resfriados e congelados com preço de mercado competitivo. É um peixe de águas paradas, bastante rústico, apresenta alta taxa de prolificidade, é tipicamente herbívoro e sua carne é de sabor agradável, apresenta pouca susceptibilidade a doenças parasitárias, alto teor de domesticidade, resistência a baixas concentrações de oxigênio e grande precocidade. Sua introdução na aqüicultura nacional apresenta-se bastante promissora, além de ser a 
espécie mais difundida e recomendada para a criação intensiva em tanques e açudes (Bard, 1980; Castagnolli, 1992; Vaz \& Parreira, s.d.). Segundo Madrid (2000) pelo Programa Avança Brasil de desenvolvimento e incentivo à aqüicultura, em 1999 a produção nacional de tilápia apresentou-se em torno de 42.918 toneladas e a meta para 2003, é de 86.416 toneladas. Porém, por não ser espécie considerada "nobre", deve receber tratamentos para se tornar mais conveniente e atrativa ao consumo.

A produção mundial da tilápia nilótica, em 1994, foi de 426.776 toneladas, contribuindo com cerca de $20 \%$ da produção de peixes oriundos da aqüicultura, sendo o continente asiático o maior produtor mundial. A produção brasileira, em 1993, foi de 26.700 toneladas com tendência de grande crescimento para os próximos anos (FAO, 1996). Atualmente, algumas regiões do Brasil vêm apresentando grande desenvolvimento no cultivo desta espécie, uma vez que, tem-se a possibilidade de manejo para o aproveitamento de resíduos da filetagem para a fabricação de silagem, que serve para o enriquecimento de rações animais. Na região oeste do Estado do Paraná, a área em lâmina de água aproxima-se de 2.000 ha, com cerca de 5.000 produtores envolvidos economicamente na piscicultura, sendo que a estimativa de produtividade é de $3.000 \mathrm{~kg} / \mathrm{ha}$, ressaltando que em sistemas semi intensivos e intensivos consegue-se produtividade de 8.000 a $16.000 \mathrm{~kg} / \mathrm{ha}$ por safra, cujo peso comercial de $400 \mathrm{~g}$ é atingido em um período de quatro a oito meses, dependendo do sistema de cultivo adotado e da época do ano (Marchi, 1997; Pinto, 2000; Visentainer et al., 2000). 
A atividade pesqueira deve ter um conhecimento exato sobre o que, onde, quando, quanto e como pescar, além de como aproveitar melhor os recursos disponíveis (Faulhaber, 1988). O estresse e as alterações mecânicas causadas durante a captura, bem como, na estrutura e composição de pescado, mudanças durante o período pós-mortem, declínio do pH e o tempo que o pescado permanece no gelo antes do desembarque (ou não permanece) podem induzir rapidamente o desenvolvimento microbiológico (Church, 1998).

\subsection{Pescado como matéria prima}

Nos dias atuais, a indústria de pesca tem crescido consideravelmente, tanto pelo aumento da demanda do consumidor, como pelas inovações tecnológicas pelas quais a indústria está passando, porém é necessário acompanhar estas inovações com a melhoria nos programas de inspeção de qualidade e de processamento. $\mathrm{O}$ pescado por apresentar algumas características peculiares inerentes ao modo de captura, sua biologia e tipos de processamento, torna-se diferente de outros alimentos de origem animal, requerendo para isto, um processamento apropriado (Dams et al., 1994). Segundo Leitão (1977), o pescado é tido como mais susceptível ao processo de deterioração do que outros produtos cárneos, por ter rápida ação destrutiva de suas enzimas, característica menos ácida da carne e facilidade de oxidação dos lipídeos presentes. Portanto, segundo a FAO (1968) a utilização do peixe em larga escala tornou-se possível somente depois que o efeito preservativo do gelo e/ou do uso da refrigeração tornaram-se uma prática comercial. 
É importante destacar que, em tecnologia de alimentos, não se pode obter um produto final de alta qualidade a partir de matéria prima inferior ou mesmo razoável. Dentre os principais fatores que influem decisivamente na qualidade do pescado processado, destacamse a composição do produto, a manipulação e o tratamento anterior ao processamento (Ferreira, 1987).

O mercado consumidor do exterior mantém inspetores em tempo integral junto aos produtores ou exige laudos técnicos de empresas especializadas, a fim de verificar e controlar a qualidade do produto que chega, via importação. A inspeção sanitária permite a liberação do pescado para o comércio varejista ou indústria alimentícia, somente do produto em boas condições higiênico-sanitárias. No entanto, assim que o pescado é liberado, forma-se uma extensa cadeia de comercialização que propicia o desenvolvimento de contaminações microbiológicas. Em adição, vários esporos de bactérias podem reduzir o tempo de vida do produto, alterando o odor, cor e viscosidade, além de levarem a outros problemas, como a ação enzimática que pode interagir com a microbiológica (Germano et al., 1998). A deterioração do pescado se instala logo após a morte e avança com o tempo, sendo que a velocidade de decomposição depende dos fatores exógenos (peixe passa a um meio adverso ao seu habitat) e endógenos (se constitui em excelente substrato para o desenvolvimento microbiano) (Oetterer, 1998).

Segundo Leitão (1994) o pescado está sujeito a processos de deterioração que envolvem a atividade enzimática, a rancificação de gorduras e principalmente a atividade de microrganismos presentes em sua superfície, guelras e trato intestinal. Embora a predominância 
de um ou outro destes fatores de deterioração mude, em função da composição do pescado, condições de captura e estocagem, intensidade de manuseio, entre outros, sabe-se que a participação microbiana é um dos principais fatores determinantes da vida útil deste alimento. Em pescado proveniente de águas temperadas analisam-se como características, predominância de espécies psicrotróficas, predominância de espécies com metabolismo pouco ativo na utilização de carboidratos, mas com atividades proteolíticas e lipolíticas e microrganismos aeróbios. Já o estudo da microbiota do pescado fluvial, considera que em pescado de águas temperadas/frias, tem-se a predominância de espécies Gram - sobre os Gram +; em pescado fluvial capturado em regiões tropicais, ainda se observa a predominância de Gram -.

Segundo Oetterer (1999) as espécies de pescado cultivado podem ou não apresentar características adquiridas de sabor na carne devido ao tipo de alimentação recebida, de qualquer forma recomenda-se no Brasil, a depuração dos peixes, mantendo-os pelo menos 24 horas sem alimentação antes do abate, sendo que tal água deve ser isenta de resíduos da ração, bem como não apresentar contaminantes.

A aplicação dos princípios do Programa de Análise de Perigos e Pontos Críticos de Controle, internacionalmente conhecido como HACCP (Hazard Analysis Control Critical Point) no processamento de pescado oferece um programa de inspeção melhorado e modernizado, identificando os pontos críticos nas operações de processamento do pescado, determinando seu controle e desenvolvendo um esquema de inspeção que satisfaça as 
regulamentações estabelecidas, através do monitoramento de manutenção dos registros permanentes (Dams et al., 1994).

A contaminação biológica no preparo de alimentos tem um importante papel na transmissão de doenças para seres humanos. Cerca de $70 \%$ das doenças transmitidas pelos alimentos, no mundo, desenvolvem-se em crianças menores de 5 anos, segundo dados da Organização Mundial da Saúde, sendo causadas por contaminações microbiológicas em alimentos, incluindo países em desenvolvimento, em particular quando há carência alimentar e as práticas de higiene são inadequadas. O processamento de alimentos com radiação ionizante, ao lado de outras metodologias, pode ajudar a superar estes riscos (MayerMiebach, 1993).

Sob este ponto de vista, a água é o primeiro ponto crítico que deve ser observado; se os peixes provierem de tanques com chão de terra pode haver estruturação de cepas não proteolíticas de Clostridium botulinum (anaeróbico e resistente a baixas temperaturas) e chegar a um nível indesejável de contaminação; além, do tanque de recepção estar em fluxo contínuo ou com agitadores, pois não pode haver água parada. De acordo com Bligh (1971) em contraste com a pesca marinha, o ambiente no qual o pescado de água doce é capturado pode variar de águas claras e geladas a quentes, turvas e contaminadas. Esta diferença, relacionada à qualidade da água, tem influência sobre a preservação da qualidade do pescado de água doce. Contudo, apesar deste fato, a deterioração do pescado de água doce não difere, basicamente, em muito daquela do pescado marinho, no que for decorrência da ação bacteriana e autólise. 
Quanto ao abate, Oetterer (1999) recomenda que este seja feito imediatamente após a captura, evitando que os peixes sofram fadiga e percam as reservas energéticas, importantes para mantê-los mais tempo na fase pré rigor-mortis, sendo que o abate por choque térmico é mais efetivo, pois se feito por aumento do $\mathrm{CO}_{2}$ na água, pode levar ao aparecimento do rigor mais cedo, e o pescado irá para o processamento já passível de sofrer a ação de microrganismos da flora intestinal e enzimas viscerais.

Os peixes ao serem retirados da água, morrem por asfixia, causada pela interrupção do fornecimento de oxigênio. O excessivo acúmulo de produtos metabólicos não oxidados no sangue e nos músculos paralisa o sistema nervoso e a partir daí, ocorrem a hiperemia e a liberação de muco, caracterizados assim como pré-rigor, com período que varia de 1 a 2 horas. Nesta fase o glicogênio é utilizado como fonte de energia e o ATP (trifosfato de adenosina) combinado com a miosina impede a formação do complexo actomiosina, mantendo a carne macia e o pH em torno de 7,0. O ATP é desfosforilado e passa a ADP (difosfato de adenosina) liberando energia, e é ressintetizado enquanto houver glicogênio. $\mathrm{O}$ ADP com uma nova desfosforilação passa a AMP (monofosfato de adenosina) que desamina a IMP. Esgotado o conteúdo de glicogênio, a miosina combinada com o ATP é liberada, ocorre a formação de ácido láctico a partir da degradação do glicogênio, distinguindo-se aí a passagem do pré-rigor para o rigor-mortis, que pode durar de 2 a 18 horas com um pico após 6 horas. O estresse elevado do peixe ocasiona um consumo elevado de glicogênio, restando pouca quantidade para ser utilizado como fonte de energia nesta fase (Ogawa \& Maia, 1999). Portanto, o rigor-mortis é definido como a perda da elasticidade e 
extensibilidade dos músculos, como resultado da alteração dos ciclos de contração e relaxamento (Contreras-Gusman, 1994).

Após a morte do peixe ocorrem alterações físicas, químicas e biológicas em seu corpo que, se não forem interrompidas, levam o produto a um estado de deterioração que inclui a liberação de muco, o rigor-mortis, a autólise e a decomposição bacteriana. Tal processo permanece ativo, uma vez que os sistemas enzimáticos permanecem ativos após a morte e, se houver substratos e cofatores suficientes, continuarão a produzir metabólitos que se acumularão no decorrer da armazenagem (Ferreira, 1987). A velocidade destas reações pode ser diminuída grandemente com a refrigeração, ou detida por longos períodos pelo congelamento. As reações post-mortem podem ser classificadas, de acordo com os efeitos que causam, como: modificações das propriedades físicas dos músculos, degradação dos carboidratos (evolução do glicogênio), degradação dos nucleotídeos (evolução do ATP) e alteração das proteínas (desnaturação e autólises) (Contreras-Gusman, 1994).

Segundo Botelho (1970) citado por Sales et al. (1988), dentre os alimentos cárneos, o pescado é o que se decompõe mais rapidamente devido a sua constituição pobre em tecido conjuntivo, como também a característica especial do tecido muscular, que tem o $\mathrm{pH}$ aumentado após a morte.

Dois processos contribuem para a putrefação precoce do pescado sendo o primeiro de natureza bioquímica, conhecido por autólise ou autodigestão, que é ocasionada pela ação das enzimas sobre o próprio músculo. $\mathrm{O}$ segundo e principal agente causador da putrefação 
são as bactérias que se encontram no muco exterior, nas brânquias e no intestino, em quantidade considerável (Sales et al., 1988).

Segundo Ogawa \& Maia (1999) o pescado vivo utiliza o oxigênio para o metabolismo orgânico, realizando reações de decomposição e biossíntese. Entretanto, após a morte, em condições anaeróbias, as reações de decomposição passam a prevalecer.

As bases nitrogenadas voláteis totais (BNVT) compreendem compostos como amônia, trimetilamina e dimetilamina. No início do processo degradativo, a base volátil mais representativa é a amônia, originária dos produtos da desaminação dos derivados do ATP. Posteriormente, a amônia proveniente da degradação de outros compostos nitrogenados, a exemplo de aminoácidos, juntamente com a trimetilamina formada a partir do óxido de trimetilamina, passam a se fazer presentes (Molteno et al., 1968; Ogawa \& Maia, 1999).

Segundo Contreras-Gusman (1994) durante a estocagem com gelo, as BNVT são produzidas com maior velocidade pelas bactérias aeróbicas porém, em períodos prolongados, as anaeróbicas facultativas assumem importância. A necessidade de esquematizar e simplificar o estudo da composição muscular (carne), tem levado a dividir o nitrogênio total em dois grupos: compostos nitrogenados protéicos totais (NT) e não-protéicos (NNP). A diferença entre NT e NNP, corresponde ao nitrogênio protéico que, multiplicado por 6,25, fica expressado como proteína. Na Tabela 1 são apresentados os valores de nitrogênio de várias espécies brasileiras.

O significado de qualidade é amplo, diz respeito a todas as características que o consumidor, ou comprador de pescado, consciente ou inconsciente, estima que o produto 
deva ter, ou seja, deve abordar sua composição intrínseca, valor nutritivo, grau de alteração, provável alteração durante a elaboração, armazenamento, distribuição, venda, apresentação ao consumidor, considerações estéticas, rendimento e benefícios do produtor e intermediário (Taha, 1988).

Tabela 1- Componentes nitrogenados em músculo de peixes brasileiros de água doce.

\begin{tabular}{lcccc}
\hline Espécies & $\begin{array}{c}\mathrm{N}-\text { Total }(\mathrm{NT}) \\
(\mathrm{mg} / 100 \mathrm{~g})\end{array}$ & $\begin{array}{c}\mathrm{NNP} \\
(\mathrm{mg} / 100 \mathrm{~g})\end{array}$ & NNP/Nt x 100 & $\begin{array}{c}\text { Proteínas } \\
(\mathrm{g} / 100 \mathrm{~g})\end{array}$ \\
\hline Mandi & 2552 & 210 & 8,22 & 14,6 \\
Corimbatá & 2880 & 253 & 8,80 & 16,4 \\
Tilápia & 3256 & 343 & 10,50 & 18,2 \\
Pacu & 3052 & 327 & 10,70 & 17,0 \\
Carpa & 2949 & 330 & 11,20 & 16,4 \\
Tambaqui & 2923 & 332 & 11,30 & 16,2 \\
\hline
\end{tabular}
Fonte: Contreras-Gusman, 1994.

A higiene e sanitização são prerrogativas do serviço de inspeção; assim, o controle da qualidade do pescado deve manter as condições higiênico sanitárias do ambiente e dos equipamentos, estabelecendo os procedimentos de limpeza e periodicidade (Oetterer, 1999). 


\subsection{Processamento de pescado refrigerado}

O pescado refrigerado é definido pelo Regulamento de Inspeção Industrial e Sanitária de Produtos de Origem Animal (RIISPOA) de 1962, no artigo 438 e parágrafo $2^{\circ}$, como: "Entende-se por resfriado, o pescado devidamente acondicionado em gelo e mantido em temperatura entre $0,5^{\circ} \mathrm{C}$ e $-2,0^{\circ} \mathrm{C}^{\prime}$. As normas não mencionam, porém os produtos refrigerados processados, como filés ou postas ou mesmo inteiros descamados, eviscerados e descabeçados e embalados. No artigo 441 faculta ao critério do Departamento de Inspeção de Produtos de Origem Animal (DIPOA), a obrigatoriedade da evisceração para que possa ser apresentado ao consumo. No artigo 442 passa a estabelecer os padrões organolépticos desejáveis nos vários tipos de pescado e no 445 mostra as características que definem o pescado como impróprio para o consumo (Brasil, 1976).

Segundo Fennema (1985), a refrigeração é definida como a estocagem a temperaturas acima de $0^{\circ} \mathrm{C}$ e até $15^{\circ} \mathrm{C}$ resulta na conservação do alimento, por retardar o crescimento microbiano e as atividades metabólicas post-mortem dos tecidos animais, controlar as reações químicas deteriorativas, incluindo o escurecimento enzimático oxidativo, a oxidação de lípides e alterações químicas associadas com a degradação de cor, além de controlar a autólise do pescado e de evitar perda de umidade e de nutrientes de alimentos em geral. $\mathrm{O}$ resfriamento deve ser feito logo após o abate, para manter a qualidade do músculo, como maciez, capacidade de retenção de água e cor; o músculo deve estar frio quando o pH se estabilizar. É interessante registrar que pequenas alterações na temperatura podem ser efetivas no aumento da vida útil, além de evitar ou retardar as reações químico-enzimáticas envolvidas 
no processo de autólise como também, o desenvolvimento de microrganismos que contribuem para a deterioração do alimento (Ogawa \& Maia, 1999).

A refrigeração mantém o valor nutritivo do pescado, se conduzida com técnica, evitando o drip que certamente arrastaria nutrientes, componentes solúveis do músculo, como alguns aminoácidos e vitaminas hidrossolúveis, e utilizando embalagens para proteção contra a desidratação na câmara fria, que poderia provocar a oxidação dos componentes lipídicos, como os ácidos graxos e as vitaminas lipossolúveis (Oetterer, 1998). Portanto, tanto a refrigeração quanto a manutenção do peixe sob gelo, são métodos mais adequados para conservá-los após a captura, sendo que a proporção adequada, de peixe/gelo, para se obter uma boa conservação deve ser de 2:1 (Eddie, 1983).

Mujica (1988) ressalta que tilápias evisceradas e inteiras são consideradas inadequadas para o consumo, no período de nove horas à temperatura ambiente e três dias no gelo, uma vez que processos oxidativos interagem conforme a temperatura se altera.

As bactérias do pescado de zonas tropicais são predominantemente mesofílicas e o resfriamento é a técnica mais usualmente aplicada após a captura; esta diferença de temperatura afeta sobremaneira a microbiota que predominará no armazenamento resfriado. $\mathrm{O}$ pescado deverá estar resfriado para $3^{\circ} \mathrm{C}$ dentro de 1 hora após a captura, com auxílio de gelo adicionado à água dos tanques; alertar para o fato do gelo ser suscetível à contaminação por microrganismos psicrotrópicos (Oetterer, 1999).

Lima dos Santos (1981), apresenta extensa revisão sobre o tempo de estocagem de peixes mantidos em gelo; assim para espécies de água doce tropical, devido à microbiota 
predominantemente mesofílica, há a possibilidade de estocagem por períodos de 12 a 36 dias, superiores às dos peixes de clima frio, cuja estocagem é de 5 a 18 dias.

Disney (1969) discute a utilização de peixes tropicais, particularmente no Brasil, Índia e África, como uma necessidade para incremento da oferta de pescado, além dos tradicionais de águas frias de alto valor comercial. As tilápias, por exemplo, após 20 horas de captura já podem apresentar $10^{3}$ a $10^{5}$ microrganismos/g de tecido, ao serem armazenados no gelo, após 19 dias chegam a ter a contagem de $10^{8}$ bactérias $/ \mathrm{cm}^{2}$ de pele, este fato sugere que, após a estocagem sob gelo, as espécies tropicais apresentam baixo crescimento microbiano.

\subsection{Composição e valor nutritivo do pescado}

O consumo de pescado é ainda pequeno, quando comparado ao das outras fontes de proteína de origem animal, como a carne de aves e as carnes vermelhas, motivado pela falta de tradição (gostos e hábitos); pequena oferta do produto, devido a baixa produção brasileira; falha da indústria processadora em oferecer produtos de conveniência, de fácil preparo e diversificados; bem como em razão de um sistema de distribuição e comercialização ineficiente e oneroso. Atualmente, novos incentivos à aqüicultura estão surgindo, e entre as espécies de maior cultivo está a tilápia nilótica que, em virtude de suas características zootécnicas e de processamento, vem despertando grande interesse dos criadores e processadores (Marchi, 1997).

Um maior interesse foi voltado ao pescado, após a expansão da nutrição como área de conhecimento, que apresentou as vantagens do pescado como alimento, devido ao seu valor 
nutritivo, principalmente em relação aos altos teores das vitaminas A e $\mathrm{D}$, da qualidade dos lipídeos do pescado marinho, bem como, a presença de proteínas de alto valor biológico, que podem ser utilizadas para o preparo de farinha enriquecida na alimentação infantil, além de se constituírem em ótima fonte de cálcio e fósforo (Oetterer, 1991; Sikorski et al., 1994).

Segundo Kraut (1957) citado por Sanchez (1989) o conteúdo protéico das carnes de pescado varia de 15 a $24 \%$, considerando a ingestão de $200 \mathrm{~g}$ de carne de pescado, onde a qualidade e o teor de aminoácidos presentes nas proteínas, unidos à sua digestibilidade, garantem um suprimento nutricional ao organismo considerado como excelente, como pode ser observado na Tabela 2.

Tabela 2- Necessidades diárias de aminoácidos essenciais e conteúdo destes no pescado.

\begin{tabular}{lcc}
\hline Aminoácidos & $\begin{array}{c}\text { Necessidades diárias } \\
(\mathrm{mg})\end{array}$ & $\begin{array}{c}\text { Conteúdo em 200 g de filé de pescado } \\
(\mathrm{mg})\end{array}$ \\
\hline Valina & 1,6 & 2,0 \\
Treonina & 1,0 & 1,6 \\
Leucina & 2,2 & 2,8 \\
Isoleucina & 1,4 & 2,0 \\
Lisina & 1,6 & 3,2 \\
Metionina & 2,2 & 1,2 \\
Fenilalanina & 2,2 & 1,4 \\
Triptofano & 0,5 & 0,4 \\
\hline
\end{tabular}

Fonte: Kraut (1957). 
A composição de aminoácidos essenciais no pescado é completa, balanceada e bastante semelhante entre as espécies dulcícolas e marinhas. Quanto às proteínas da carne, a miosina é rica em ácido glutâmico (22,5\%), ácido aspártico, lisina, leucina e isoleucina, que juntos perfazem cerca de 55\% dos aminoácidos totais (Geiser \& Borgstron, 1962), e pode variar em função da espécie, tamanho, sexo e época do ano, compreendendo, geralmente, cerca de $20 \%$ do total das proteína (Ogawa \& Maia, 1999).

O músculo do pescado pode conter 60 a $85 \%$ de umidade, aproximadamente $20 \%$ de proteína bruta, 1 a 2\% de cinza, 0,3 a 1\% de carboidrato e 0,6 a 36\% de lipídeos, sendo que este último componente apresenta esta variação em vista do tipo de músculo corporal analisado e espécie de peixe analisada (por exemplo, a carne dorsal apresenta menor quantidade lipídica do que a carne abdominal), sexo, idade, época do ano, habitat e dieta. Os lipídeos exercem importante papel como fonte energética, são constituintes de membranas celulares, nutrientes essenciais (ácidos graxos essenciais e vitaminas lipossolúveis), substâncias controladoras de metabolismo, substâncias isolantes de temperatura e protetores contra danos mecânicos externos (Dean, 1990; Ogawa \& Maia, 1999).

Para Sikorski (1990), o pescado magro apresenta um alto teor de umidade, podendo chegar até $83 \%$; ao contrário, o pescado gordo, pode atingir um mínimo de $58 \%$ de umidade, que se concentra nos músculos claros e na zona caudal do peixe.

Para peixes de carne vermelha como arenque, sardinha e cavalinha que migram para desova, os lipídeos de depósito constituem uma importante fonte energética e base para o desenvolvimento das gônadas. Já para os peixes de carne branca como bacalhau e merluza, a 
maioria dos lipídeos do músculo (80 a 90\%) é composta de fosfolipídeos e seu conteúdo quase não varia durante o ano, com exceção para o fígado, que é rico em lipídeos neutros e que sofrem variações de acordo com a estação do ano (Dean, 1990; Ogawa \& Maia, 1999).

Dentre os carboidratos do pescado estão o glicogênio e mucopolissacarídeos mas, também existem açúcares livres e fosfossacarídeos. Seu conteúdo é de 0,3 a 1\%, mas, certos mariscos estocam parte da reserva energética como glicogênio, o qual contribui para o característico sabor adocicado destes produtos (Ogawa \& Maia, 1999).

O pescado é boa fonte de vitaminas, no entanto, na prática, nos processos de conservação, como durante a cocção, podem ocorrer perdas devido à lixiviação pelo calor, luz, oxigênio e enzimas. Dentre as vitaminas encontradas estão vitamina A, D e E, como lipossolúveis, e tiamina, riboflavina, piridoxina, ácido nicotínico, ácido pantotênico, ácido fólico e vitamina $\mathrm{C}$, entre outras hidrossolúveis. Com relação aos minerais, encontram-se no músculo dos peixes sódio, potássio, cálcio, magnésio, fósforo, cloro, enxofre, ferro, iodo, cobre, zinco, selênio, cromo e níquel, entre outros (Ogawa \& Maia, 1999).

Segundo Ferreira (1987) os peixes podem ser considerados como fontes das vitaminas A e D, sendo que alguns concentram até 50.000 UI de vitamina A e 45.000 UI de vitamina D por grama de fígado. Os peixes magros são mais pobres em vitamina A e os elasmobrânquios, ou peixes cartilaginosos, apresentam apenas traços de vitamina D.

Um consumo mais acentuado de pescado se iniciou quando sua qualidade nutricional foi destacada, uma vez que apresenta um balanço protéico, de vitaminas e minerais 
(especialmente cálcio, fósforo e ferro) associado a um baixo valor calórico, superior ao da carne vermelha (Venugopal et al., 1999).

As vitaminas hidrossolúveis (principalmente as do complexo B) estão presentes no tecido muscular de pescado, enquanto as lipossolúveis (vitamina A, D, E, K) estão distribuídas por todo o organismo do pescado. As vitaminas hidrossolúveis são relativamente perdidas em processos de cocção seguidos de estocagem. Durante a irradiação do pescado, perdas de vitaminas são similares às ocorridas com processamentos que envolvem altas temperaturas. Niacina é a vitamina mais resistente e perdas de tiamina podem ser minimizadas sob condições de refrigeração (Pigott \& Tucker, 1990).

Certas vitaminas podem ser destruídas durante o processamento por irradiação de um alimento, sendo que estas perdas são decorrentes de alguns fatores, como a dose empregada, o meio em que foi irradiado o alimento, além das condições de armazenamento. Portanto, as perdas de vitaminas que ocorrem durante a irradiação de um alimento são similares às de um processamento térmico, ou seja, geralmente a perda é pequena (FAO/IOEA/OMS, 1966).

A fração cinza de peixes de água doce apresenta variações em quantidades que vão desde 0,90 a 3,39\%. Com relação aos minerais, a carne de pescado é considerada uma fonte valiosa de cálcio e fósforo em particular, apresentando quantidades razoáveis de sódio, potássio, manganês, cobre, cobalto, zinco, ferro e iodo (Contreras-Gusman, 1994).

De um modo geral, os peixes têm mais tecido muscular que outros animais criados para consumo humano, como os frangos, porém assemelham-se a outros animais consumidos em termos de proteína, cerca de 15 a $22 \%$. Sua porcentagem comestível varia de 47 a $60 \%$, 
conforme a espécie, estágio de desenvolvimento e tipo de processamento (Machado, 1994; Prado, 1984).

Com relação ao conteúdo de lipídeos, os peixes dividem-se em dois grupos: peixes magros e peixes gordos conforme a idade, estado biológico, tipo de alimentação e do estado de nutrição do peixe, como também, da temperatura da água (Sanchez, 1989). Uma característica da fração lipídica de peixes é o seu alto teor em ácidos graxos insaturados, que embora seja uma característica nutricionalmente positiva, é preocupante industrialmente, pois quanto mais insaturado o lipídeo maior a possibilidade de desenvolvimento do ranço (Prado, 1984). A oxidação ou autoxidação consiste em uma série de reações em cadeia, resultando em inúmeros compostos tais como álcoois, cetonas, hidrocarbonetos, ácidos, entre outros, os quais conferem sabores e odores de ranço, sendo muitas vezes, fator de rejeição do produto (Khayat \& Schwall, 1983). O processo é chamado de autoxidação, pois uma vez iniciado torna-se difícil controlá-lo, devido à intensa formação de moléculas altamente reativas conhecidas como radicais livres, que atacam em cadeia os lipídeos do pescado. O processo oxidativo inicia-se logo após a morte do pescado, podendo ser favorecido pela exposição ao ar atmosférico, temperatura elevada, desidratação e presença de agentes pró-oxidantes; as proteínas do sangue e músculo (hemopigmentos) são agentes catalisadores destas reações (Machado, 1994). 


\subsection{1 Ácidos graxos insaturados}

A revalorização dos óleos marinhos veio a ser consequiência da campanha pela redução do colesterol dietético, que estimulou o consumo de óleos polinsaturados de origem vegetal. Os polinsaturados de origem marinha foram aceitos inicialmente com reticência porém, após os anos 60, as evidências de que as populações cuja alimentação era baseada em produtos marinhos tinham menor incidência de doenças isquêmicas do coração, incentivaram as pesquisas em nível nutricional e clínico (Contreras-Gusman, 1994).

Segundo Oetterer (1991) as doenças vasculares, como a aterosclerose, podem ser minimizadas com a ingestão de pescado, uma vez que estes apresentam ácidos graxos com ligações do tipo ômega-3, que são mais ágeis para abaixar o colesterol sangüíneo. Fisiologicamente, os ácidos polinsaturados do tipo ômega-3 dificultam a formação das placas ateromatosas. As lipoproteínas do sangue ficam menos densas, mais fluídas e portanto, pouco capazes de transportar o colesterol e os triglicérides para os tecidos do corpo. Todavia, os óleos de peixe não fazem parte do hábito alimentar dos consumidores brasileiros, além de terem tendência à oxidação, pela presença dos ácidos graxos polinsaturados.

O elemento chave da saúde dos esquimós foi descoberto por médicos dinamarqueses, que ao estudarem a alimentação dos esquimós, que é basicamente composta por peixes e suas gorduras, perceberam a presença de lipídeos com cadeias carbônicas entre 20 e 22 átomos. Dentre estes, encontravam-se os ácidos graxos ômega-3: eicosapentaenóico (20:5 $\omega$-3; EPA) e o docosahexaenóico (22:6 $\omega$-3; DHA). Existem distinções bioquímicas e principalmente, funcionais entre eles; o EPA age mais diretamente no sistema vascular, enquanto o DHA 
modifica as propriedades coagulantes das plaquetas sangüíneas (Ackman, 1994; ContrerasGusman, 1994).

Pigott \& Tucker (1990) destacam que os ergosteróides e 7-dehidrocolesterois (esterol animal) são as duas pré-formas de vitamina D. Alimentos de origem vegetal apresentam altos índices de ácidos graxos polinsaturados (PUFAs), todavia alguns destes, contém somente duas ligações insaturadas. Já os óleos animais apresentam quatro duplas ligações, porém um alto índice de ácidos graxos saturados. Somente os óleos de pescado apresentam longas cadeias de ácidos graxos com cinco ou seis duplas ligações, contendo, em média, 50\% de ácidos graxos polinsaturados.

A maioria dos ácidos graxos existentes no pescado contém 14 a 22 átomos de carbono, podendo ser saturados ou insaturados, monoênicos ou poliênicos. A composição em ácidos graxos varia de acordo com a espécie do animal, hábito alimentar, estação do ano, temperatura da água, dieta, habitat e estágio de maturação. Dentre os ácidos graxos insaturados mais comuns no pescado estão, principalmente o ácido monoênico (18:2 $\omega 9)$,

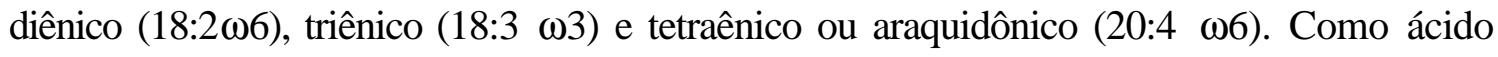
pentaenóico, o principal é o ácido eicosapentaenóico (EPA) ou 20:5 ف3, e como hexaenóico, o ácido docosahexaenóico (DHA) ou 22:6 w3 (Ogawa \& Maia, 1999).

A porção lipídica dos alimentos pode estar associada, positiva ou negativamente, às diversas propriedades dos alimentos como sabor, estabilidade da cor, características emulsificantes e conteúdo calórico. A diferença entre espécies, em relação à composição de ácidos graxos, representa uma das variáveis mais significativas que determinam as 
características de processamento, palatabilidade e armazenamento de peixes, carnes bovinas e de aves, entre outros alimentos. Os ácidos graxos insaturados, especialmente os polinsaturados, são lábeis à oxidação, problema sério no processamento e armazenamento destes alimentos (Maia \& Rodriguez-Amaya, 1993).

Os alimentos com elevados teores de lipídeos possuem ácidos graxos que diferem nas suas propriedades químicas e físicas, como também, na suscetibilidade à oxidação, bem como, apresentam outros componentes não-lipídicos que podem co-oxidar e/ou interagir com os lipídeos oxidados e seus produtos de oxidação. Desma maneira, alguns fatores podem estar presentes durante o processo oxidativo interagindo na reação, dentre eles estão, a composição de ácidos graxos, presença do oxigênio, temperatura, umidade, presença de pró-oxidantes, luz visível, energia radiante, entre outros (Bombo, 1998).

O tipo de ácidos graxos das gorduras dos peixes de água doce resultam da combinação dos ácidos graxos ingeridos na dieta e das modificações para funções fisiológicas, que são realizadas nos tecidos específicos. A armazenagem da gordura para energia ocorre de maneira quase semelhante aos peixes marinhos: há um acúmulo nas paredes da cavidade abdominal como depósitos semi-sólidos, sob a pele, no fígado, nos tecidos mesentéricos e nos músculos. Exceto nestes últimos, os outros tecidos refletem, de maneira muito próxima, os ácidos graxos da dieta. Nos peixes tropicais de água doce, é freqüente encontrar peixes semimagros, porém com grandes depósitos localizados na cavidade abdominal (tambaqui, matrinxã, curimbatá) (Contreras-Gusman, 1994). 
Estudos mostram que a administração de ácidos graxos ômega-3 reduz as chances de mortalidade por doenças cardiovasculares. As tendências dietéticas atuais promovem a utilização de óleos vegetais como fonte lipídica da dieta, os quais são ricos em ácido araquidônico (20:4 $\omega-6)$, como pode ser observado na Tabela 3 (Ackman, 1994).

Tabela 3- Ácidos graxos (g/100 g) constituintes de partes comestíveis de peixes comerciais.

\begin{tabular}{|c|c|c|c|c|c|}
\hline $\begin{array}{l}\text { Ácidos } \\
\text { graxos }\end{array}$ & $\begin{array}{l}\text { Bacalhau } \\
\text { (Gadus } \\
\text { morhua) }\end{array}$ & $\begin{array}{c}\text { Arinca } \\
\text { (Melanogramms } \\
\text { aeglefinus) }\end{array}$ & $\begin{array}{c}\text { Solha } \\
\text { (Pleuronects } \\
\text { virens) }\end{array}$ & $\begin{array}{c}\text { Alabote } \\
\text { (Hipoglossus) }\end{array}$ & $\begin{array}{l}\text { Salmão } \\
\text { (Salmo } \\
\text { solar) }\end{array}$ \\
\hline $14: 0$ & Traços & Traços & 0,05 & 0,05 & 0,56 \\
\hline $16: 0$ & 0,14 & 0,11 & 0,25 & 0,17 & 2,20 \\
\hline $16: 1$ & 0,01 & 0,02 & 0,23 & 0,14 & 0,70 \\
\hline $20: 1$ & 0,01 & 0,01 & 0,06 & 0,10 & 0,98 \\
\hline $18: 2 \omega-6$ & Traços & 0,01 & Traços & 0,04 & 0,16 \\
\hline $20: 4 \omega-6$ & 0,02 & 0,02 & 0,04 & 0,24 & 0,06 \\
\hline $20: 5 \omega-3$ & 0,11 & 0,07 & 0,17 & 0,29 & 0,96 \\
\hline $22: 6 \omega-3$ & 0,21 & 0,14 & 0,14 & 0,41 & 1,29 \\
\hline
\end{tabular}

Fonte: Ackman, 1994.

Especificamente, os lipídeos de pescado contêm ácidos graxos polinsaturados de cadeia longa da família $\omega 3$ (AGPI $\omega 3$ ), sendo que esta tendência é mais clara em peixes marinhos do que de água doce. O conteúdo de AGPI $\omega 3$ é mais alto em fosfolipídeos do que 
em lipídeos neutros. Por isso, observa-se que em espécies que contém menor teor de lipídeos, há uma tendência de apresentarem maior proporção de AGPI 133 (Ogawa \& Maia, 1999).

Maia (1992) pesquisando peixes de água doce como pacu, tilápia e corimbatá, demonstrou que os ácidos graxos polinsaturados dos fosfolipídeos correspondiam, principalmente, ao C20:4 $\omega 6$ e C22:6 $\omega 3$, cada um contribuindo, em média, com 10\% dos ácidos graxos, incluindo, ocasionalmente, C22:5 $\omega 3$ e C20:5 $\omega 3$ em níveis próximos a 5\%.

\subsection{Contaminação microbiológica do pescado}

Dos alimentos cárneos, o pescado é o que se decompõe mais rapidamente; isto devido a sua constituição pobre em tecido conjuntivo, como também as suas características especiais do tecido muscular que tem o pH aumentado após a morte (Sales et al., 1988). Por ser rico em nutrientes, principalmente proteínas, é muito susceptível ao ataque e/ou desenvolvimento microbiano, além de poder sofrer alterações de natureza física ou química, que irão se refletir geralmente em sua cor, consistência, odor e sabor, podendo além de acarretar perdas do produto, ocasionar risco à saúde dos consumidores (Brasil, 1976). Microrganismos e enzimas iniciam os processos de decomposição protéica, sendo que a maioria dos microrganismos presentes no pescado apresenta atividade proteolítica e lipolítica, contribuindo para a desintegração dos tecidos e levando a uma série de reações bioquímicas indesejáveis (Kai \& Morais, 1988).

A contaminação bacteriana da carne se origina basicamente nos intestinos, no limo superficial e nas guelras, sendo que a remoção das vísceras é normalmente considerada 
benéfica à preservação da qualidade. Todavia, quando o animal morre, as enzimas proteolíticas existentes nas vísceras atacam os órgãos e os tecidos adjacentes, degradando-os ou tornando-os tão debilitados que à mais leve fricção ou pressão se desprendem, além do que as bactérias invadem os tecidos através das guelras, ao longo das artérias e veias, diretamente pela pele e peritônio (Amlacher, 1961; Andrade, 1975; Connell, 1988; Eiroa, 1980; Shewan, 1961).

Como a decomposição do pescado é causada principalmente pelas bactérias, uma das maneiras de retardar essa decomposição é diminuir a temperatura até um nível em que as bactérias não cresçam ou o façam muito lentamente (Tornes \& George, 1976). Dentre as bactérias que concorrem para a putrefação do pescado temos: Pseudomonas, Micrococcus, Flavobacterium, Serratia e Bacillus entre outras (Sales et al., 1988), sendo os microrganimos principais os psicrófilos, que também são proteolíticos, bem como, podem ser encontradas outras bactérias como os coliformes, clostrídios, Salmonella, Staphylococcus aureus e Vibrio, podendo os mesmos estar relacionados com a matéria-prima, o ambiente ou ainda serem conseqüência de manuseio e/ou estocagem incorretos durante o processamento e a comercialização (Hoffmann et al., 1999).

O crescimento microbiano foi estudado por Gram \& Huss (1999), que demonstraram que inicialmente microrganismos aeróbicos crescem na superfície do peixe, e quando a superfície começa a modificar-se e aumentar o muco residual, começa o desenvolvimento de bactérias anaeróbicas. 
Enquanto o peixe está vivo sua pele atua como uma barreira mecânica à penetração das bactérias, razão pela qual seu músculo, quando recentemente capturado, é considerado estéril. Logo após a morte o peixe perde suas defesas tornando-se vulnerável ao ataque microbiano. O tipo de deterioração observado pode ser em grande parte atribuído a alterações nos tecidos dos peixes, causadas pelo ataque de tipos específicos de bactérias e dos produtos gerados por elas. A extensão da deterioração é determinada pela carga bacteriana inicial, pela temperatura do músculo do peixe, pelo tempo decorrido depois de sua morte e pelas práticas sanitárias adotadas (Leitão et al., 1977).

No Brasil, a Portaria n. 451 de 19/09/97 do Ministério da Saúde, SVS (1997), fixa os seguintes padrões microbiológicos para pescado in natura, fresco e refrigerado:

- Salmonella: ausência em 25g.

- Coliformes fecais: máximo de $10^{2} / \mathrm{g}$.

- Staphylococcus aureus: máximo de $10^{3} / \mathrm{g}$.

- Contagem padrão em placas: máximo de $10^{6} / \mathrm{g}$.

As bactérias coliformes são importantes nas alterações dos alimentos pela sua capacidade de crescer bem em inúmeros substratos e por utilizar como fonte de energia um grande número de hidratos de carbono e alguns compostos nitrogenados como fonte de nitrogênio, pela capacidade de síntese da maioria das vitaminas que necessitam, além de produzirem, a partir dos açúcares, consideráveis quantidades de ácidos e gás, podendo ocasionar sabores anormais (Jay, 1970). 


\subsection{Efeito das radiações ionizantes nos alimentos}

O uso de novas tecnologias permite que cada vez mais os produtos sejam diversificados, acompanhando as tendências mundiais de alimentos prontos e de fácil preparo. Uma das vantagens em processar os alimentos, é a de se poder apresentá-lo de forma mais atraente que a tradicional, não exigindo o desgaste de limpar e eviscerar, no caso de pescado, além de permitir estocagem por maior tempo, sem perda de seus atributos organolépticos (Beirão et al., 2000).

Somente determinados tipos de radiações ionizantes possuem propriedades adequadas para o tratamento de alimentos. São radiações eletromagnéticas, em forma de raios gama ou de raios $\mathrm{X}$. Os raios gama são radiações com comprimentos de onda que se originam na desintegração espontânea do núcleo atômico de certos elementos; os raios X são de igual natureza, porém são produzidos por geradores. Tanto os raios gama como os raios $\mathrm{X}$ são muito penetrantes e efetivos (FAO/IOEA/OMS, 1966).

Segundo Truswell (1987), baixas doses de radiações ionizantes (abaixo de 1,0 kGy) são capazes de inibir o brotamento de batatas e cebolas; já doses entre 5 e 10 kGy, aumentam a vida útil de alimentos, reduzindo a carga microbiana e eliminando microrganismos não-esporulados em condimentos, carne de aves e pescado.

A irradiação de alimentos é um tratamento que consiste em submeter os alimentos, já embalados ou a granel, a uma quantidade minuciosamente controlada de radiação ionizante, por um tempo prefixado e com objetivos bem determinados. O processo não aumenta o nível de radioatividade normal dos alimentos e as radiações ionizantes poderão ser utilizadas nos 
alimentos em geral, com energia inferior ao limiar das reações nucleares, que poderiam induzir radioatividade no material irradiado. No caso de radiações gama, que apresentam um elevado poder de penetração nos tecidos de forma homogênea, não existe aumento significativo de temperatura durante o processamento. A dose média global absorvida por um alimento submetido a um processo de irradiação não deve exceder $10 \mathrm{kGy}$, com a finalidade de assegurar a inocuidade do alimento irradiado, sob os pontos de vista toxicológico, nutricional e microbiológico, conforme especifica a legislação brasileira (Diehl, 1992; IAEA, 1989; Rela, 2000).

A radurização (pasteurização a frio) é um processo de irradiação a ser utilizado para estender o frescor dos peixes mantidos no gelo ou sob refrigeração, reduzindo a incidência da deterioração causada por bactérias. Dois fatores são determinantes na escolha da dose de radurização, a qualidade e quantidade de mudanças no crescimento microbiológico e a manutenção dos atributos organolépticos deste alimento. Bactérias Gram negativas são radiosensíveis e grandemente responsáveis pela deterioração de produtos de pescado, sendo portanto, necessário uma baixa dose de radiação para inativá-las. A radurização é suficiente na dose de 1 a 3 kGy para reduzir uma contagem inicial de organismos deterioradores de 1 para 3 ciclos logaritmos (Poole et al., 1994; Ryder et al., 1983; Sikorski, 1990;).

Segundo Rela (2000) nos últimos 30 anos foram realizadas pesquisas científicas utilizando técnicas analíticas, altamente precisas, com o objetivo de isolar e detectar produtos radiolíticos formados durante o processo de irradiação, sendo que não foram detectadas substâncias que sejam produzidas exclusivamente nos alimentos irradiados. 
A irradiação de alimentos é essencialmente um processo "frio", porque este tratamento não causa um aumento da temperatura. Todavia, a temperatura do produto irradiado influencia na mudança de radiação-induzida, ou seja, reações entre radicais livres aumentam com a temperatura, afetando a taxa total de radiólises. Baixas temperaturas, reduzem a produção de compostos voláteis em alimentos, os quais afetam a qualidade sensorial do alimento irradiado. Estas alterações são minimizadas em produtos congelados (Merrit et al., 1985).

De 1970 a 1982 estudos foram coordenados pelo International Project (IFIP) com sede em Karlsruhe, na Alemanha. O "Joint Expert Committee” constituído pela World Health Oorganization das Nações Unidas, FAO "Food and Agriculture Organization" e IAEA “International Atomic Energy Agency" concluíram, no ano de 1980, que a irradiação de qualquer alimento, até a dose de $10 \mathrm{kGy}$, não apresenta perigo toxicológico nem tampouco alterações nutricionais. Tal julgamento foi razão para a elaboração dos padrões no Codex Alimentarius quanto à segurança do alimento irradiado e medidas de controle e documentação deste procedimento; as normas de aplicação à irradiação de alimentos, estipulam que os alimentos irradiados destinados à exportação devem ser acompanhados de documentos de embarque, nos quais devem estar identificados o irradiador, o lote, a dose e outros detalhes do tratamento. Tais alimentos devem estar devidamente embalados e etiquetados para identificação, além de ser utilizado o termo "irradiado" ou "tratado por radiação ionizante", bem como estar presente o símbolo internacional para alimento irradiado conforme a Figura 1 (Bruhn \& Wood, 1996; ICGFI/IAEA, 1991; Lusk et al., 1999; Mayer-Miebach, 1993). 
Figura 1-Símbolo Radura

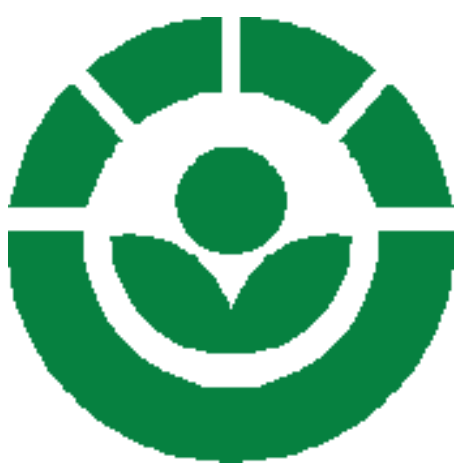

A aceitação depende da confiança sobre a qualidade e a segurança apresentada pelos alimentos irradiados juntamente com o custo, sendo que o sucesso da comercialização dos produtos irradiados no mercado interno, ocorrerá se houver a aceitação destes, por parte do mercado externo, além de se adaptarem facilmente à atual tendência a alimentos embalados e à mecanização da indústria alimentícia. Em 1997, após três anos de estudo, o FDA (Food \& Drug Administration), aprovou o uso da irradiação em carne bovina, uma vez que esta preserva a qualidade dos alimentos sem alterar o sabor, a aparência ou o aroma, além do produto poder ser irradiado já embalado (Savitci et al., 1997).

A irradiação pode ser utilizada juntamente com outros métodos de conservação de alimentos como a refrigeração, tratamento térmico, cura e a adição de substâncias químicas, a fim de prolongar, consideravelmente a vida útil de alguns alimentos durante o período de armazenamento, tanto refrigerado como não, sendo necessário um envase perfeito que não permita uma nova contaminação, uma vez que o alimento estará isento de qualquer flora microbiológica (FAO/IOEA/OMS, 1966). 
Rela (2000) destaca que os macronutrientes como proteínas, carboidratos e gorduras são estáveis ao processo de irradiação. Os micronutrientes, especialmente as vitaminas, podem ser sensívies a qualquer método de tratamento de alimento, incluindo a irradiação.

Os alimentos em geral, contêm componentes chave que, embora presentes em concentrações muito baixas, regulam o seu sabor, aspecto e o valor nutritivo (WHO, 1994). Esses componentes são muito sensíveis à irradiação e, se a dose de radiação for alta, pode causar transformações prejudiciais no sabor, no odor e na cor desses alimentos (Singh et al., 1995). Em relação ao processo tecnológico, as radiações ionizantes podem agir negativamente sobre os lipídeos que rancificam devido à oxidação (Hutzier, 1997). Todavia, Al-Kahtani et al. (1996) destacam que o efeito da irradiação nos lipídeos é similar às mudanças resultantes do emprego do calor ou processos oxidativos, sendo que tal efeito é minimizado na exclusão do oxigênio.

Gruiz et al. (1987) analisaram as mudanças ocorridas na fração lipídica após a irradiação de frangos e observaram que em doses altas (50 kGy) apareceram reações de oxidação lipídica, enquanto em doses mais baixas (4 kGy) não ocorreram alterações significativas.

Doses maiores que 3 kGy desencadeiam processos de oxidação lipídica, uma vez que o pescado possui altas concentrações de ácidos graxos polinsaturados na pele e nos tecidos musculares (Ghadi \& Venugopal, 1991). A pele do pescado é a região onde a oxidação lipídica se apresenta mais marcante, devida a grande quantidade de fosfolipídios. Todavia, 
quando utilizadas baixas doses, ou doses de radurização, e com a ausência do oxigênio, os processos oxidativos são minimizados (Pigott \& Tucker, 1990).

Outra alteração importante a ser ressaltada diz respeito aos aminoácidos, que podem sofrer pequenas quebras e liberação desagradável de cheiro sulfuroso, porém deve-se lembrar que isto acontece em níveis bem baixos, não acarretando problemas no valor nutricional (Kilcast, 1994).

Os radicais livres podem se formar não somente durante o processo de irradiação, mas também mediante vários outros tratamentos convencionais de alimentos, tais como a liofilização, torrefação, fervura, os processos normais de oxidação, entre outros (Diehl, 1992; Satin, 1996; Singh et al., 1995). Tal reação desenvolve-se quando a célula é submetida às radiações ionizantes, onde vários dos seus componentes químicos podem ser atingidos com a conseqüente formação de produtos radiolíticos quimicamente estáveis, o que promove a estabilidade química das substâncias presentes no alimento (Ray, 1996; Voisine et al., 1993; Wagner, 2000).

Al-Kahtani et al. (1996) analisaram filés de tilápia do nilo (Oreochromis niloticus) e cavala-moira (Scomberomorus commersoni), irradiados com doses de 1,5 a $10 \mathrm{kGy}$, estocados por 20 dias à temperatura de refrigeração e não-irradiados, sob os aspectos de bases nitrogenadas voláteis totais (BNVT), ácido tiobarbitúrico (TBA), tiamina, riboflavina e tocoferóis. Após três semanas de estocagem, os filés não-irradiados apresentaram um aumento para 60mg/ 100g de BNVT comparados aos $35 \mathrm{mg} / 100 \mathrm{~g}$ dos filés irradiados. Quanto ao conteúdo de tiamina, este foi afetado com aplicação de doses maiores que 4,5 
kGy, porém o teor de riboflavina não foi afetado. Para o tocoferol, houve uma maior retenção desta vitamina nos filés submetidos a doses de $3 \mathrm{kGy}$. Um aumento nos valores de TBA foi observado de acordo com o aumento da dose.

Pesquisas demonstram que os macronutrientes tais como as proteínas, carboidratos e as gorduras são relativamente estáveis às doses até 10 kGy, e que os micronutrientes, principalmente as vitaminas, podem ser sensíveis a qualquer método de tratamento de alimentos (Diehl, 1992; Fox et al., 1989; Fox et al., 1992; Singh et al., 1995; WHO, 1994). Vitaminas hidrossolúveis são particularmente sensíveis a quaisquer métodos de processamento, porém as lipossolúveis são particularmente destruídas pela irradiação e os tocoferóis são os mais sensíveis nas doses de pasteurização (Diehl, 1992; Fox et al., 1989; Kilcast, 1994; Nawar, 1983).

\subsubsection{Efeito das radiações sobre os microrganismos}

Os problemas sanitários que afetam os produtos da aquiicultura, incluindo aqueles que interessam particularmente aos países em desenvolvimento, estão associados com a contaminação biológica e química que podem ocorrer durante o cultivo destes alimentos (Beirão et al., 2000).

O pescado capturado carreia uma microbiota que reflete aquela do meio ambiente e normalmente não deve albergar microrganismos perigosos ao ser humano, porém há exceções como os registros de cepas não proteolíticas de Clostridium botulinum e vibriões como o Vibrio parahaemolyticus (APPCC, 1988). 
Os peixes são propensos a contaminação por uma variedade de microrganismos, dependendo do meio em que vivem e das condições de manuseio e da temperatura. A composição da microflora de diferentes espécies de peixes provenientes de águas frias após sofrerem deterioração, apresentam bactérias Gram negativas, enquanto espécies de peixes de águas tropicais, apresentam bactérias Gram positivas, além de bactérias entéricas, destacam

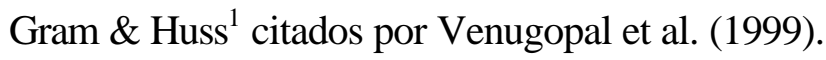

Além da gravidade da constatação de que um alimento está contaminado com microrganismos de origem fecal, a presença de E. coli pode ter um significado particularmente importante, uma vez que se constitui em linhagens enteropatogênicas, causadoras de vários surtos de gastroenterites, provocadas pela ingestão de água e/ou alimentos contaminados (Franco et al., 1985).

Segundo Figueiredo (1991) os coliformes fecais são destruídos por pasteurização ou temperaturas normais de cocção todavia, a sua resistência ao congelamento depende do grupo e do substrato. Quanto à sobrevivência em alimentos desidratados, a ocorrência de coliformes requer confirmação dos tipos encontrados. Se sua presença é confirmada,significa contaminação fecal humana, através de manuseio durante o processamento e contaminação animal, através das práticas de manejo.

Segundo a Legislação Brasileira, anexo II da portaria n n $^{0}$ 1/87 de 28 de Janeiro de 1987, do Departamento de Inspeção Nacional de Alimentos (Brasil, 1976), classifica-se como produtos potencialmente capazes de causar toxinfecções alimentares os que

${ }^{1}$ GRAM, L.; HUSS, H.H. Microbiological spoilage of fish productos. 
apresentam Staphylococcus aureus, Bacillus cereus, Clostridium perfringens e seus indicadores (clostrídios sulfito redutores, a $46^{\circ} \mathrm{C}$ ), em número superior a dez vezes os limites estabelecidos nos padrões específicos, incluindo microrganismos como Salmonella, Yersinia enterocolitica, Brucella spp., Compylobacter jejuni e outros reconhecidos e caracterizados como agentes de infecções alimentares (Gonçalvez, 1998; Silva et al., 1997).

O indicador microbiológico de poluição fecal mais empregado é o grupo coliforme; bastonetes que fermentam a lactose com formação de gás a $35^{\circ} \mathrm{C}$, bactérias Gram negativas, facultativas anaeróbicas, não esporuladas (Lima \& Oliveira, 1992; Roitman et al., 1988). São microrganismos típicos da microflora fecal, podendo ser encontrados em outras partes do corpo, como mãos e ouvido. A espécie Escherichia coli é considerada como sendo de origem unicamente fecal, pertence à família Enterobacteriaceae e pode não possuir motilidade, ou pode possuí-la através de flagelos peritríquios; sua temperatura ótima de crescimento é de $37^{\circ} \mathrm{C}$ e o $\mathrm{pH}$ em torno de 7,0. Embora E.coli faça parte da flora normal do intestino grosso dos humanos e animais, a maioria das linhagens não é patogênica, além de produzir infecções entéricas e no trato urinário, bem como, envenenamento alimentar. Pelo fato da pouca tolerabilidade dos coliformes à água do mar e a cloração, existem desvantagens apontadas de seu uso como indicadores de poluição fecal, todavia não existe outro método de escolha para tal determinação (Roitman et al., 1988).

A Salmonella constitui alto risco à saúde do consumidor por ser contaminante de alimentos manipulados sem os cuidados higiênico-sanitários, além do armazenamento e transporte dos mesmos, ser feita de maneira inadequada. Alimentos in natura de origem 
animal, são as maiores fontes de Salmonella, e o risco de se contrair uma salmonelose, tem início quando esses alimentos já contaminados entram em contato direto com o manipulador que poderá servir como agente disseminador desses microrganismos aos equipamentos, utensílios e alimentos já preparados (Roitman et al., 1988).

No Brasil, vários trabalhos demonstram a qualidade insatisfatória dos alimentos, em termos higiênicos, principalmente em relação ao patógeno $S$. aureus, visto que o Comitê Misto de Peritos da FAO/OMS, reunido em Genebra em 1980, determinou a necessidade de metodologias mais rigorosas a fim de minimizar tais riscos à saúde humana. O relatório concluiu, portanto, que a utilização de uma dose máxima de 10 kGy assegura a inocuidade dos alimentos sob os pontos de vista toxicológico, microbiológico e nutricional (OMS, 1984).

A radiação ionizante age sobre as bactérias contaminantes através da lesão de seus ácidos nucléicos, especialmente do DNA, sendo sua eliminação relacionada à intensidade da dose empregada (Hutzier, 1997), todavia não é possível produzir nos microrganismos efeitos análogos equivalentes aos que são produzidos por meio do calor, uma vez que a sensibilidade relativa dos microrganismos não é a mesma, frente às radiações, quando comparadas ao calor (FAO/IOEA/OMS, 1966). A radiação é ativa sobre os microrganismos em ordem crescente de resistência: bactérias Gram positivas, fungos, bactérias Gram negativas, bactérias esporuladas e vírus, sendo que as mais sensíveis, já o são com 2 kGy; outros microrganismos, como vírus, podem exigir doses altas como 50 kGy para serem inativados (Hutzier, 1997).

A irradiação de frangos é viável, uma vez que recentes pesquisas descrevem as destruições dos principais agentes causadores de infecções alimentares nos últimos anos, $S$. 
enteritidis, S. typhimurium, L. monocytogenes e C. jejuni. Todavia, é difícil calcular a dose mínima necessária de radiação para destruir os patógenos, pois o efeito antimicrobial depende de alguns fatores como a variação de sensibilidade dos microrganismos, esporos e alimentos com baixa atividade de água, que são mais resistentes do que culturas vegetativas (Mayer-Miebach, 1993).

Um tratamento com radiações ionizantes aplicado a um alimento, a fim de conservá-lo, deve apresentar eficácia em destruir todos os microrganismos causadores de alterações e patógenos, além da eliminação de todos os microrganismos presentes no alimento, bem como deve atuar reduzindo o número de organismos viáveis em geral, com a conseguinte melhora na conservação do mesmo. Todavia, a dose necessária para conseguir um objetivo determinado, depende não somente do tipo de microrganismo, como também, do número de microrganismos presentes no alimento, antes da irradiação e do número de organismos viáveis toleráveis ao tratamento, ou seja quanto maior o número de microrganismos presentes em um alimento antes da irradiação, maior deverá ser a dose a ser empregada (FAO/OIEA/OMS, 1966).

Segundo o Grupo Consultivo Internacional sobre Irradiação de alimentos (GCIIA, 1990), a irradiação pode impedir a divisão de células vivas, como bactérias e células de organismos superiores, pois altera suas estruturas moleculares, além de inibir a maturação de algumas frutas e legumes, ao produzir reações bioquímicas nos processos fisiológicos dos tecidos vegetais. 
Segundo a Empresa Brasileira de Radiação (Preservação..., 1996), os benefícios possíveis de se obter da irradiação são: a destruição de patógenos, eliminação de infestações de insetos em grãos e frutas tropicais, redução de contaminação microbiana em especiarias ou ainda, aumento da vida útil de produtos frescos. Segundo Truswell (1987), a irradiação de alimentos foi, inicialmente, permitida em trinta países, todavia alguns destes ainda não possuiam plantas de processamento.

Spinelli \& Pelroy ${ }^{2}$ citado por Ahmed et al. (1997) reportaram que a formação de bases nitrogenadas voláteis totais (BNVT) é reduzida em pescado irradiado, comparado com o não-irradiado, pois a radiação sensibiliza os microrganismos decompositores de óxido de trimetilamina.

A irradiação do pescado pode minimizar os problemas gerados por autoxidações enzimáticas, bem como eliminar microrganismos patogênicos, diminuindo significativamente esporos bacterianos e aumentando, dessa forma, o tempo de estocagem do produto (Ghadi \& Venugopal, 1991).

Viana (1993) utilizou várias doses de irradiação e chegou à dose de 4 kGy como sendo a menor, capaz de garantir a esterilização das amostras de pescado marinho refrigerado e inoculadas com Salmonella typhimurium, L. monocytogenes, A. hydrophila, $P$. shigelloides, Escherichia colli, Bacillus cereus, Yersinia enterocolitica e Vibrio parahaemolyticus.

${ }^{2}$ SPINELLI, J. \& PELROY, G. Quality indices that can be used to assess irradiated seafood. In: Freezing and irradiation of fish. London: Fishing News, p. 425 - 430. 1969. 
Segundo Viana (1993), doses maiores de 3kGy são efetivas na eliminação de microrganismos como Escherichia colli, L. monocytogenes, Y. enterocolítica e $A$. hydrophila que mostraram seu crescimento paralisado em filés de pescado irradiado com dose de 4 kGy. Entretanto, somente a dose de 5 kGy promoveu a eliminação efetiva de outros microrganismos como S. typhimurium, Plesiomonas shigelloides, Bacillus cereus e Vibrio parahaemolyticus. Urbain (1986) concluiu que doses de radicidação (entre 5 e 8 kGy) são mais eficientes para a inativação de bactérias patogênicas não formadoras de esporos, como Shigella, Neisseria, Mycobacterium, E. coli, Proteus, Streptococcus e S. aureus.

Hussain et al. (1985) relataram que após, apenas 7 dias de estocagem, amostras de cavalinha fresca ( $\underline{\text { Rastrelliger }} \underline{\text { canagurta }})$ não-irradiadas alcançaram os limites microbiológicos aceitáveis comparados com amostras irradiadas com 1,5 kGy, que atingiram o limite aceitável, após 2 a 3 semanas, em estocagem.

Uma dose de 1,5 kGy estendeu o tempo de estocagem sob refrigeração de cavalinha da Índia de 12 para 25 dias. Para o Pampo ( $\underline{\text { Stromateus }} \underline{\text { cinereus }})$ que foi irradiado com 1,0 kGy, a estocagem foi possível por cinco semanas sob refrigeração. O risco de contaminação por Clostridium botulinium é diminuído quando o pescado é embalado anteriormente à irradiação (Ghadi et al., 1991).

Segundo Poole et al. (1994) doses entre 0,75 e 2,5 kGy podem estender o tempo de estocagem de 2 para 6 semanas sob temperaturas de 0 a $5^{\circ} \mathrm{C}$. 


\subsubsection{Aplicações das irradiações em alimentos}

A carne suína irradiada foi o primeiro produto de origem animal a ser aprovado pelo Food and Drugs Administration (FDA), em 1985. Desde então, vários estudos nos Estados Unidos têm examinado a atitude do consumidor frente a este processo tecnológico. Resurreccion et al. (1995) reportaram que a consciência do consumidor aumentou de $23 \%$ em 1984 para 72\%, em 1995. Todavia, Lusk et al. (1999) destacam que nesta época, pouco se conhecia sobre tal tecnologia, o que se mantêm até hoje, fato que comprova a necessidade de programas educacionais sobre este processo.

Estudos realizados nos Estados Unidos analisando a aceitabilidade de carne vermelha irradiada mostraram que, a maior parte dos consumidores conhecia a irradiação de alimentos através de jornais e televisão, como sendo um processo tecnológico capaz de prolongar a vida útil do alimento e destruir as bactérias causadoras de toxinfecções alimentares, sem alterar as características físicas e químicas dos alimentos, ou com baixo índice de alteração. Todavia, mostraram-se positivos ao uso da irradiação, quando comparado ao uso de aditivos alimentares. Este estudo mostrou a necessidade de um programa educacional, a fim de apresentar esta tecnologia como sendo de vanguarda e seus benefícios para o alimento, bem como, para a segurança do consumidor de alimentos, ou seja, quando era explicado o aspecto tecnológico da irradiação, os consumidores aceitavam e adquiriam produtos irradiados sem preconceito, bem como, quando havia crianças na família do entrevistado, a aceitação ao produto irradiado era maior, em vista da segurança que o produto apresenta, além das 
mulheres mostrarem-se mais acessíveis do que os homens ao produto (Lusk et al., 1999; Resurreccion \& Galvez, 1999).

A variação do valor nutricional do alimento causada pela irradiação depende de vários fatores, entre eles a dose à qual o alimento é exposto, o tipo de alimento, a sua embalagem, as condições de tratamento, temperatura e armazenamento (Diehl, 1992; Singh et al., 1995). As perdas são menores quando o tratamento pela irradiação é conjugado com baixa temperatura e vácuo, podendo-se assim, aumentar as doses de radiação, sem prejuízo do valor nutricional do alimento (Diehl, 1992). De acordo com a Organização Mundial da Saúde, alimentos irradiados produzidos de acordo com as boas práticas de fabricação, "Good Manufacturing Practices - GMP” (Diehl, 1992; Leite et al. 2000), podem ser considerados saudáveis e de qualidade nutricional adequada.

A irradiação pode ser usada como tratamento quarentenário, sendo uma alternativa mais promissora quando comparada a princípios químicos ou outros métodos mais abrasivos (Käferstein \& Abdussalam, 1999).

As aplicações do processo de irradiação em alimentos estão destacadas no Quadro 1. 


\begin{tabular}{|c|c|c|}
\hline Propósito & Dose (kGy) & Produto \\
\hline $\begin{array}{l}\text { Doses baixas (menores que } 1,0 \\
\text { kGy) }\end{array}$ & & \\
\hline a) Inibição de brotamento & $0,05-0,15$ & Batatas, cebolas, alho, gengibre e inhame. \\
\hline b) Desinfestação de insetos & $0,15-0,75$ & $\begin{array}{l}\text { Cereais, feijões, frutas frescas e secas, } \\
\text { pescado seco, carne seca, pescado cru, } \\
\text { carne suína. }\end{array}$ \\
\hline c) Retardo do processo fisiológico & $0,25-1,0$ & $\begin{array}{l}\text { Frutas e vegetais (mangas, mamões, bananas, } \\
\text { cogumelos). }\end{array}$ \\
\hline Doses médias $(1,0$ - 10 kGy $)$ & & \\
\hline a) Extensão da vida útil & $1,0-3,0$ & Pescado e morangos. \\
\hline $\begin{array}{l}\text { b) Eliminação de microrganismos } \\
\text { patogênicos }\end{array}$ & $1,0-5,0$ & $\begin{array}{l}\text { Frutos do mar, carnes de aves, carnes } \\
\text { vermelhas cruas ou congeladas, produtos de } \\
\text { ovos, queijo Camembert. }\end{array}$ \\
\hline $\begin{array}{l}\text { c) Eliminação de esporos e } \\
\text { microrganismos patogênicos }\end{array}$ & $3,0-10,0$ & $\begin{array}{l}\text { Ervas e especiarias, condimentos, vegetais } \\
\text { desidratados, gomas. }\end{array}$ \\
\hline $\begin{array}{l}\text { d)Melhoramento das propriedades } \\
\text { tecnológicas }\end{array}$ & $2,0-7,0$ & $\begin{array}{l}\text { Uvas: aumentando a produção de suco; frutas } \\
\text { desidratadas: melhorando a rehidratação; } \\
\text { vegetais desidratados: reduzindo o tempo de } \\
\text { cocção. }\end{array}$ \\
\hline Doses altas $(10,0-100 \mathrm{kGy})$ & & \\
\hline a) Esterilização industrial & $30-100$ & $\begin{array}{l}\text { Carnes vermelhas, aves, frutos do mar, } \\
\text { alimentos preparados, dietas hospitalares. }\end{array}$ \\
\hline $\begin{array}{l}\text { b) Descontaminação de aditivos e } \\
\text { ingredientes alimentícios }\end{array}$ & $10-50$ & $\begin{array}{l}\text { Ervas e especiarias, condimentos, } \\
\text { preparados de enzimas, gomas naturias. }\end{array}$ \\
\hline
\end{tabular}

Quadro 1- Aplicações da radiação em produtos alimentícios.

Fonte: Delincée, 1996. 


\subsection{Propriedades Sensoriais dos alimentos}

Segundo Gurgel (2000) as propriedades sensoriais dos alimentos têm sido muito valorizadas nas últimas décadas, pois determinam a aceitabilidade do produto no mercado consumidor e portanto, sua viabilidade econômica.

O grau de aceitabilidade de um alimento por parte dos consumidores é afetado por fatores próprios de cada indivíduo e do ambiente que o circunda. Influem mais que nada, os hábitos e padrões culturais, além da sensibilidade individual, muito variável de pessoa a pessoa, da idade, especialmente em crianças menores de 5 anos e nos idosos, que manifestam preferências particulares, os prejuízos a respeito das expectativas sobre um produto, a fidelidade a determinadas marcas, que fazem com que o consumidor não mude de produto, a higiene e o local de consumo, o tipo e o número de acompanhantes; entre outros aspectos (Dasso, 1999).

Beirão et al. (2000) definem a análise sensorial, como uma técnica científica utilizada para evocar, medir, analisar e interpretar reações àquelas características dos alimentos quando são percebidas pelos órgãos dos sentidos, é a avaliação mais freqüente na indústria de pescado e derivados, tanto pela necessidade da rapidez do julgamento de lotes de matériaprima e do produto acabado, como pela facilidade de execução.

A análise sensorial trabalha essencialmente, com uma metodologia subjetiva, uma vez que, cada indivíduo apresenta uma resposta a respeito de alguns fatores. Para minimizar a impressão dos resultados, trabalha-se com um número apropriado de avaliadores em condições normais, desta maneira, consegue-se resultados confiáveis e reprodutíveis. Assim, 
não é possível conhecer as preferências dos consumidores e a aceitação por novos produtos (Dasso, 1999).

As propriedades sensoriais são os atributos dos alimentos detectadas por meio dos sentidos, onde ao levar um alimento à boca, o cérebro recebe a informação que liga os receptores de sabor da língua (as papilas gustativas) e os receptores olfativos que se encontram no nariz (Courthiade, 1999). A cor e a textura, são propriedades sensoriais muito importantes de um alimento, sendo mais fáceis de se avaliar do que o sabor, pois este se constitui em um fenômeno completo e dinâmico, que relaciona todos os sentidos, principalmente o olfato e o gosto. O olfato compõe a fisiologia do sabor porque, o aroma (ou odor) é o primeiro atributo que se percebe, antes até que o gosto. Um odor inadequado pode interferir ou modificar um determinado sabor (Lozano, 1999).

Os fatores que afetam o avaliar do sabor são dois: um físico e outro que depende do meio ambiente. Como fatores físicos, soma-se o sexo, idade, horário da degustação, estresse, condições de saúde e tabagismo. Quanto aos ambientais, estão a temperatura, calor e outros elementos relacionados. Para avaliar-se o sabor dos alimentos há distintos métodos, como o ensaio por preferência, comparação pareada, ensaio duo-trio, análises descritivas de atributos sensoriais, determinação do perfil livre (para sabor ou textura) e técnicas combinadas (Lozano, 1999).

Uma perda na qualidade sensorial com a utilização de altas doses de irradiação limita o uso da mesma. De acordo com dados da literatura, os atributos sensoriais em frango 
irradiado, bem como em ovos e derivados não foram afetados com a dose de $3 \mathrm{kGy}$, todavia em doses maiores tem-se uma alteração no "flavor" (Mayer-Miebach, 1993).

A avaliação sensorial é considerada satisfatória na avaliação da qualidade de peixes, apresentando vantagens adicionais como rapidez, baixo custo, não é destrutiva e está relacionada aos critérios de aceitação adotados pelos consumidores. Entretanto, no pescado processado como filés e postas de peixes congelados e conservas, estas características perdem a sua intensidade, dificultando a avaliação da qualidade (Soares et al., 1998).

Segundo Huss et al. (1974) a análise sensorial completa, é a que determina a avaliação do frescor do pescado, visando um melhor aspecto quanto a qualidade do produto. Nenhum teste químico, por si, pode ser considerado satisfatório para medir o grau de deterioração do pescado, portanto, a análise sensorial tem sido usada como principal parâmetro coadjuvante da avaliação da qualidade do pescado. 


\section{MATERIAL E MÉTODOS}

\subsection{Pescado}

Foram utilizados peixes provenientes de cultivos do Estado de São Paulo, da região de Piracicaba que estão iniciando a comercialização, da espécie tilápia-do-Nilo $\underline{\text { Oreochromis }}$ niloticus). A quantidade total de peixes obtida para a pesquisa, representou cerca de $95 \mathrm{~kg}$, com um peso médio de 450 a $700 \mathrm{~g}$, coletados com rede e mantidos em um tanque, em depuração, por 24 horas antes de serem abatidos. Após este período, foram distribuídos em caixas de isopor, contendo gelo, preparado com água potável, e transportados diretamente ao Setor de Processaemnto de Alimentos do Departamento de Agroindústria, Alimentos e Nutrição da ESALQ - USP.

\subsection{Beneficiamento da matéria-prima}

Os peixes foram eviscerados, descabeçados, retiradas as escamas e lavados com água corrente (Figura 2), cortados em postas e divididos em dois grupos, distribuídos em recipientes de vidro, tipo "placas de Petri”, para posterior irradiação e armazenamento 
durante 1, 20 e 30 dias, conforme a Figura 3. Filés dispostos em bandejas de isopor e embalados com filme de PVC (cloreto de polivinila) esticável foram armazenados por 1 e 20 dias, conforme a Figura 4. Para a análise sensorial, foram utilizados filés irradiados armazenados por até 30 dias. Mantiveram-se amostras não irradiadas como controle.

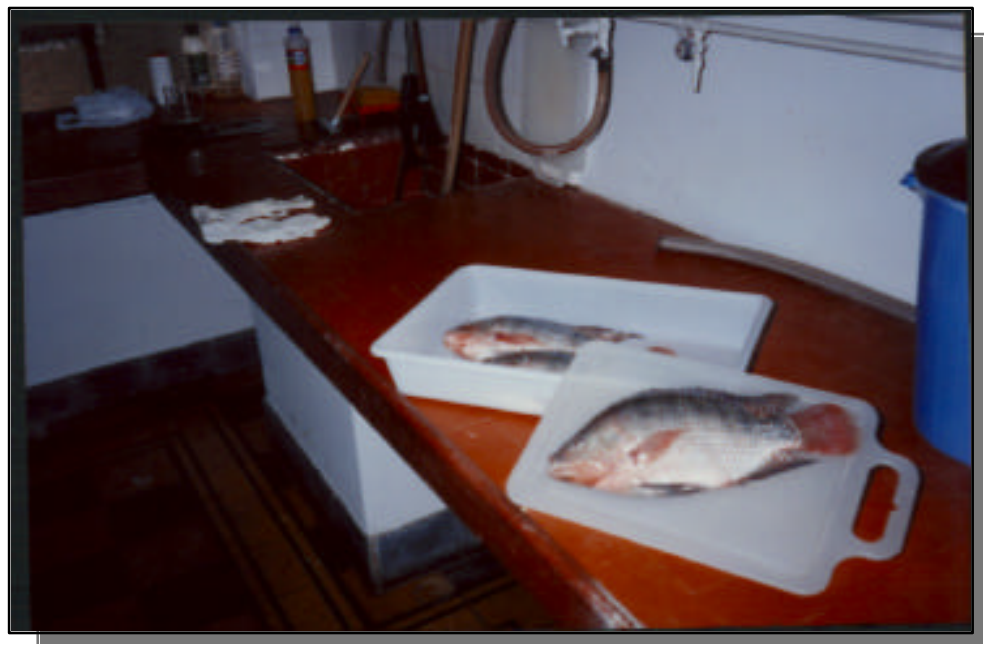

Figura 2- Limpeza e manipulação do peixe.

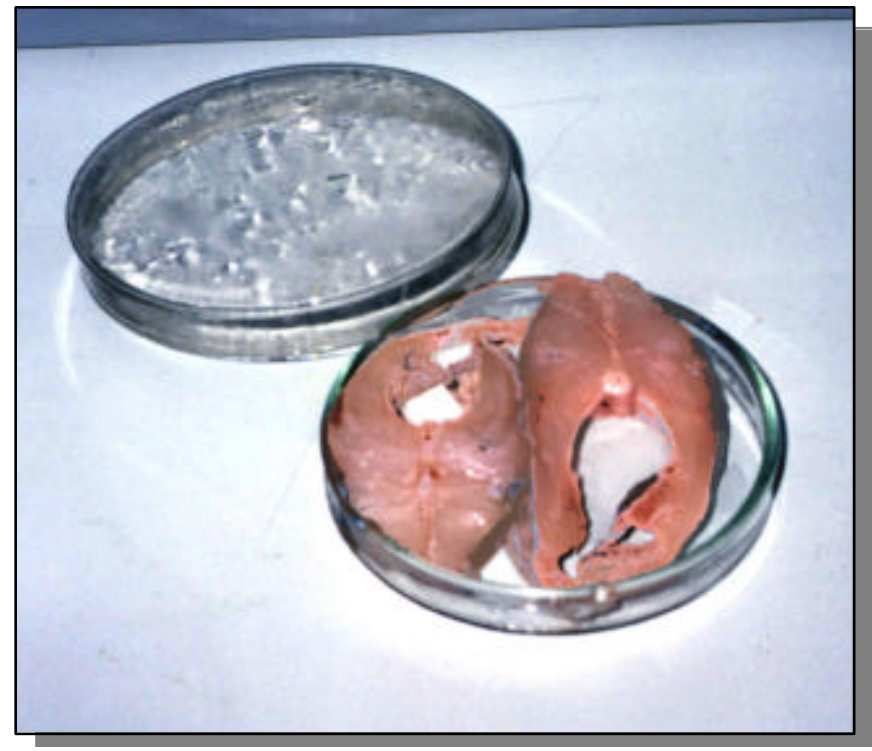

Figura 3 - Postas de peixe armazenadas em recipiente tipo "placa de Petri" para posterior irradiação e armazenamento refrigerado. 


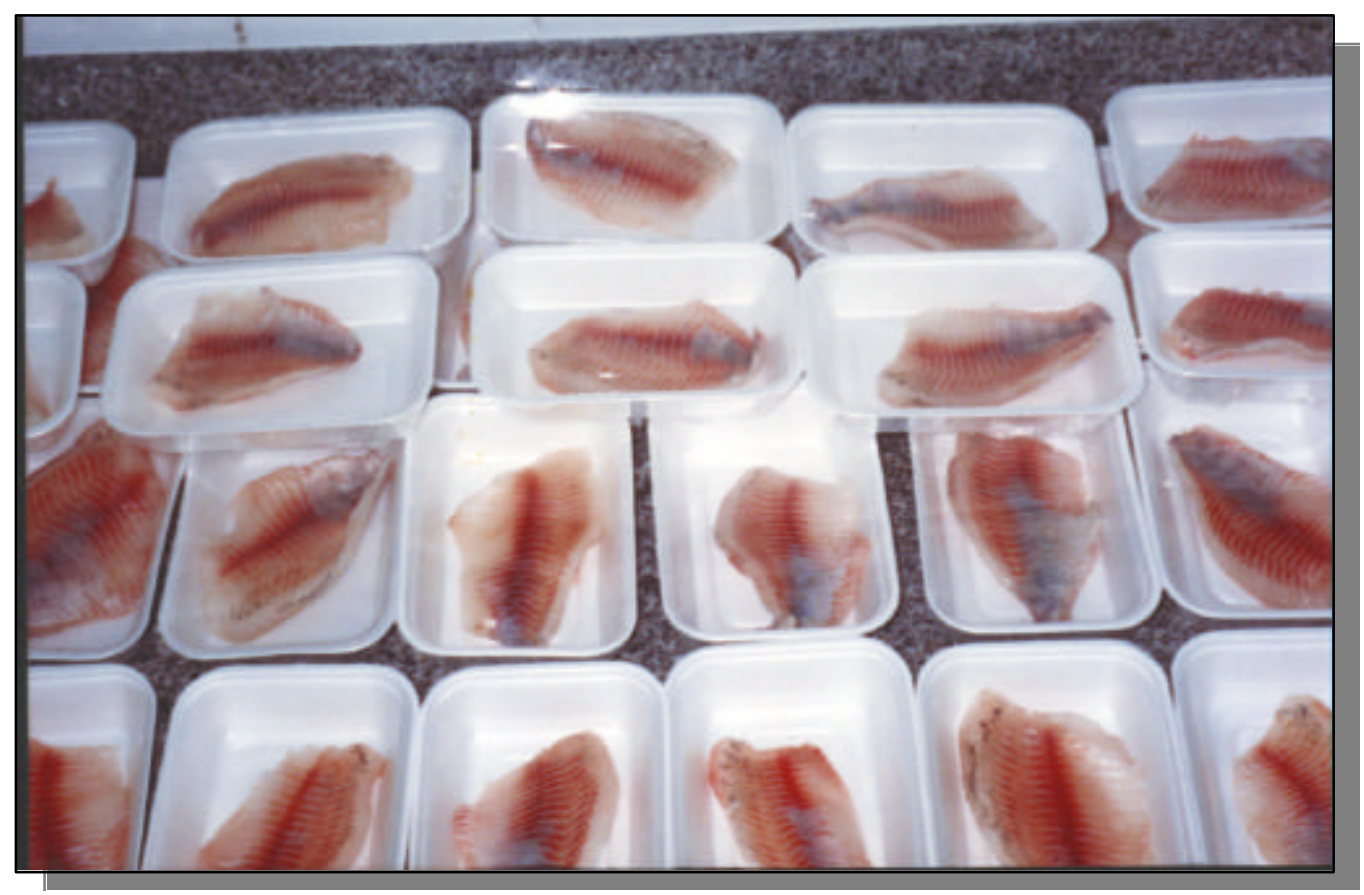

Figura 4 - Filés de tilápia dispostos em bandejas de isopor para posteior irradiação e armazenamento refrigerado.

\subsection{Irradiação do pescado}

A irradiação das amostras de pescado foi efetuada em um irradiador de Cobalto-60 semicomercial para alimentos, modelo Gammabeam 650 da Nordion, Otawa-Canadá, instalado no CENA, Centro de Energia Nuclear da Agricultura da ESALQ/USP, em Piracicaba - SP, conforme Figura 5. Empregaram-se as doses de 1,0 e 2,2 kGy (preconizadas pela legislação para desinfestação de deteriorantes) e 5kGy (considerada eficiente para descontaminação de microrganismos patogênicos não formadores de esporos), com uma taxa de dose de 0,627 kGy/h, e manteve-se a dose controle sem irradiação. 
Adicionou-se gelo seco a estas amostras para manter a temperatura baixa durante o período de irradiação.

As amostras utilizadas para a análise sensorial, foram congeladas a $-24^{\circ} \mathrm{C}$, para manter a temperatura baixa durante a irradiação que foi efetuada em um irradiador de Cobalto-60, modelo Gammacell 220 Excel, da MDS Nordion, Otawa-Canadá. Empregou-se as doses de 1,0; 2,2 e 5,0 kGy com uma taxa de dose de 1,505 kGy/h, mantendo-se a dose controle sem irradiação.

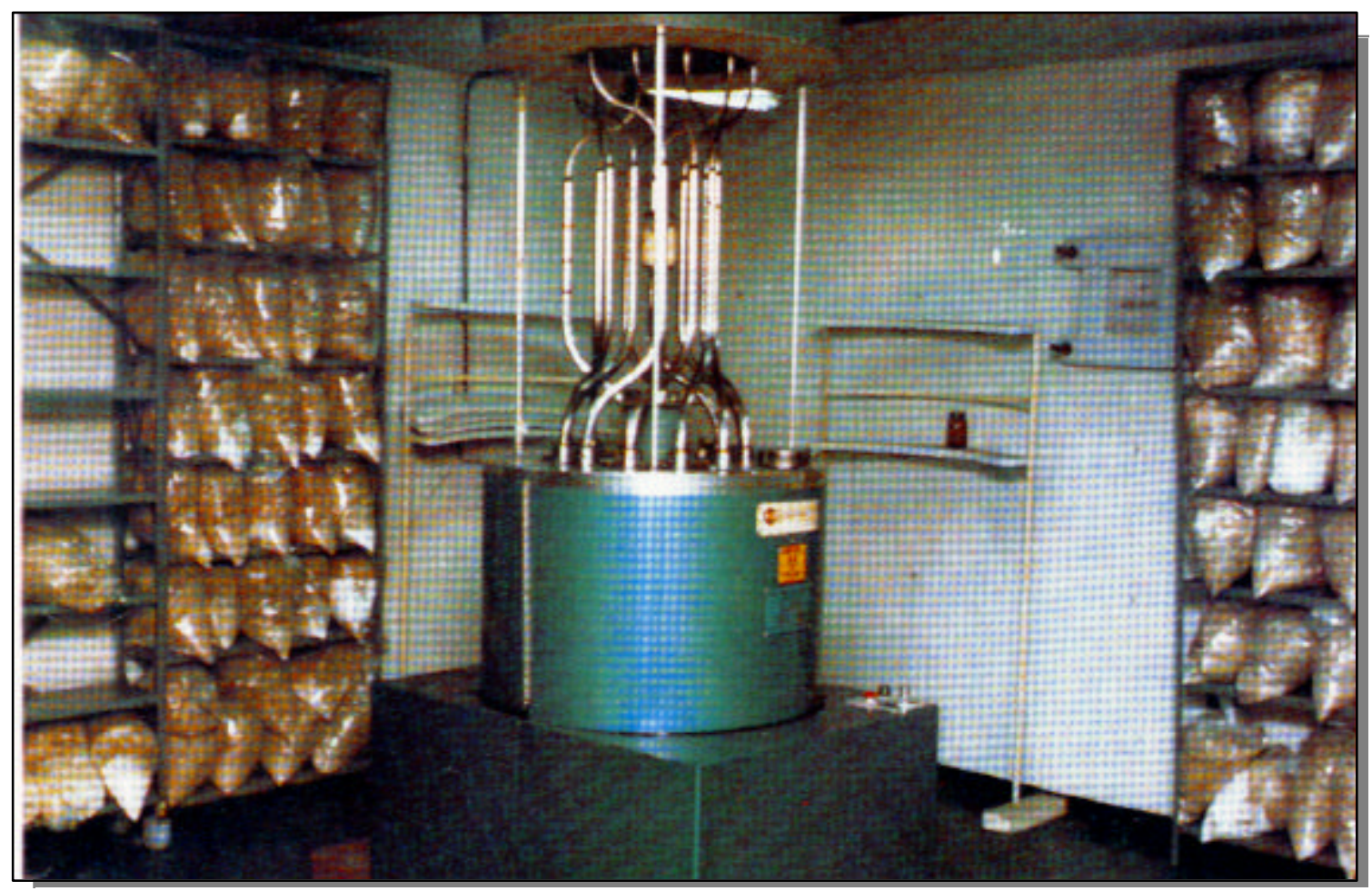

Figura 5 - Fonte de Cobalto-60, modelo Gammabean 650 da Nordion, Otawa/Canadá, utilizada para a irradiação das amostras de pescado. 


\subsection{Refrigeração do pescado}

Após a irradiação, as amostras irradiadas foram submetidas a refrigeração na faixa de 0,5 a $-2^{\circ} \mathrm{C}$, conforme recomendação do RIISPOA, Regulamento de Inspeção Indústrial e Sanitária de Produtos de Origem Animal (Brasil, 1976) e mantidas por períodos de 20 e 30 dias sob armazenamento refrigerado, juntamente com a amostra não irradiada ou controle, conforme a Figura 6. A temperatura média do refrigerador variou de 0,5 a $1^{\circ} \mathrm{C}$.

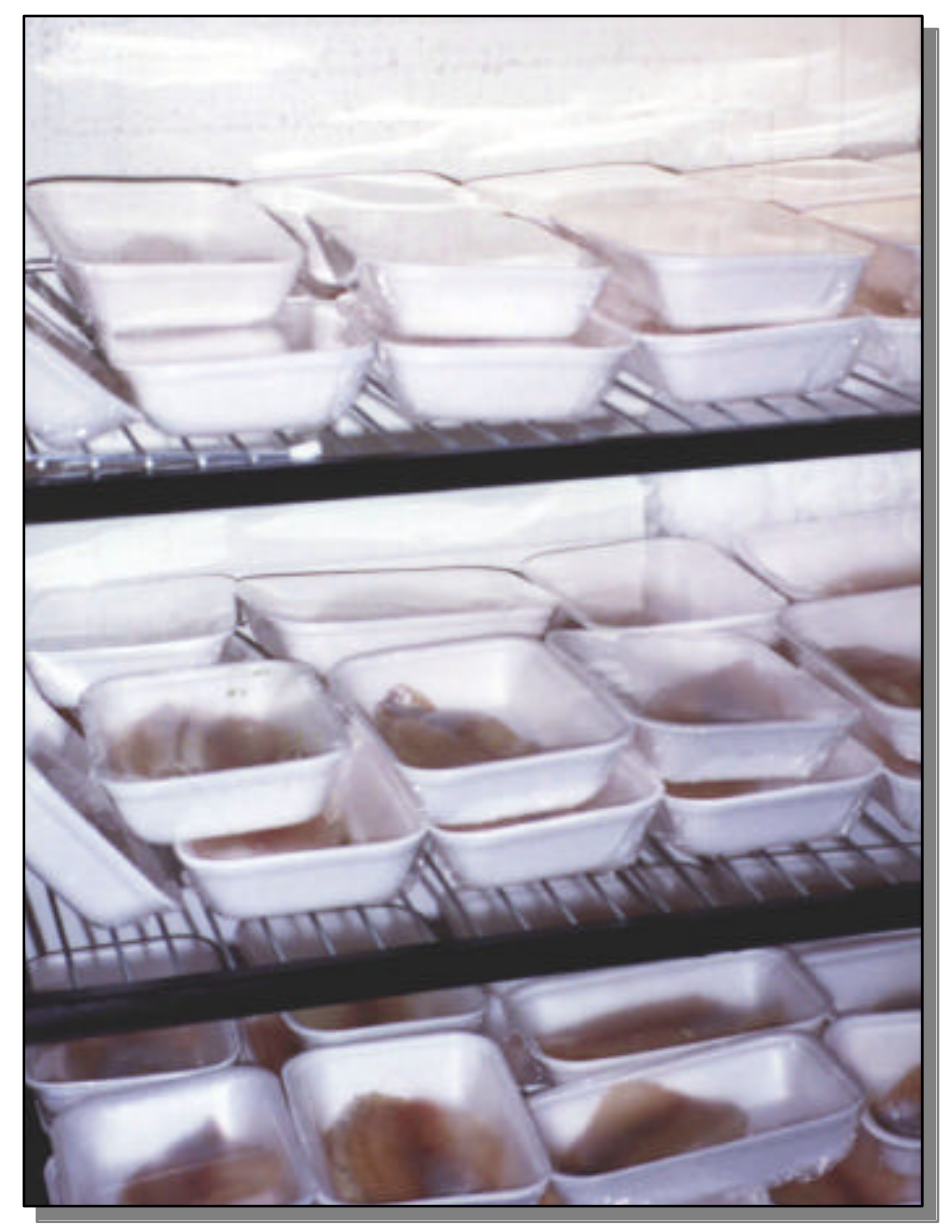

Figura 6 - Armazenamento refrigerado. 


\subsection{Análises microbiológicas}

Análises microbiológicas de tilápia não irradiada e irradiada estocados por 1, 20 e 30 dias sob refrigeração, foram feitas para verificar se psicrotrófilos, coliformes totais e fecais, Salmonella e Staphylococcus aureus, estavam presentes, conforme Vanderzant \& Splittstoesser (1992). As análises para coliformes foram realizadas com "kits simplate", que apresentam leitura após 24 horas. A metodologia baseia-se no uso do substrato definido, que permite correlacionar a presença de coliformes totais e Escherichia coli com a presença de $\beta$-galactosidade e $\beta$-glucoronidase, respectivamente, em 24 horas a $35^{\circ} \mathrm{C}$. $\mathrm{O}$ número de cavidades positivas é convertido em contagem total, utilizando-se uma tabela para número mais provável.

Para a determinação de Staphylococcus aureus foram realizadas diluições de $10^{-1}$, $10^{-2}$ e $10^{-3}$ tomando uma fração de $0,1 \mathrm{ml}$ colocada em placa contendo meio Baird Parker Agar (BPA) e feito o espalhamento com alça de Drigalsky, sendo realizado em duplicata, para cada diluição e incubação a $35-37^{\circ} \mathrm{C}$ por 24 horas (Silva et al., 1997).

Para a determinação de psicrotrófilos utilizou-se o meio Ágar Padrão para contagem (PCA), com incubação a $7^{\circ} \mathrm{C}$ por 10 dias (Silva et al., 1997).

Na detecção de Salmonella, utilizou-se o método Oxoid Salmonella Rapid Test (OSTR), sendo que foram pesados $25 \mathrm{~g}$ de carne de pescado e colocados em erlenmeyer, com $225 \mathrm{ml}$ de água peptonada tamponada esterilizada para o pré-enriquecimento, que objetiva a recuperação de células injuriadas. A solução foi incubada a $37^{\circ} \mathrm{C}$ por 24 horas. 
Quando na dúvida a respeito do resultado obtido, utilizou-se para confirmação o teste sorológico Salmonella Latex Test da Oxoid.

\subsection{Análises físico-químicas e nutricionais}

Para as amostras não irradiadas e irradiadas e armazenadas por 1, 20 e 30 dias sob refrigeração, foram realizadas as seguintes análises físico-químicas:

3.6.1 Composição centesimal: umidade, proteína, lipídeos e cinza, de acordo com A.O.A.C. (1995).

3.6.2 Nitrogênio não protéico, conforme A.O.A.C (1995).

3.6.3 Bases nitrogenadas voláteis totais, de acordo com Pregnolato \& Pregnolatto (1985).

3.6.4 Determinação do pH, em equipamento digital Digimed.

Nas amostras não irradiadas e irradiadas e armazenadas por 1 e 20 dias sob refrigeração, foram realizadas as seguintes análises:

3.6.5 Determinação de aminoácidos, com analisador de aminoácidos, segundo Moore \& Stein (1963).

3.6.6 Ácidos graxos, de acordo com Firestone (1998).

3.6.7 Vitamina A e tiamina, de acordo com A.O.A.C. (1995).

3.6.8 Análise de TBARS (substâncias reativas ao ácido tiobartitúrico), de acordo com Tarladgis et al. (1960).

\subsection{Análise sensorial}

O teste hedônico ou de aceitabilidade foi realizado no laboratório de análise sensorial no Departamento de Agroindústria, Alimentos e Nutrição na ESALQ/USP, no horário da 
tarde (14:30 - 17:00). No primeiro dia, a execução do teste constou de 35 a 40 provadores, não treinados e escolhidos aleatoriamente. Participaram do teste provadores de ambos os sexos, com idade entre 25 a 40 anos. Foram consideradas as habilidades na percepção das diferenças em relação ao aroma e aparência das amostras. Os provadores compararam o pescado in natura, recém capturado, apenas mantido sob refrigeração até a análise, com as várias amostras experimentais após irradiação e refrigeração. Foram realizados outros dois testes similares, correspondendo aos 20 dias e 30 dias de armazenamento refrigerado, conforme mostra a Figura 7.

Foi utilizada uma escala hedônica de 9 pontos ancorados em seus extremos os termos: gostei muitíssimo (9) e desgostei muitíssimo (1), conforme modelo apresentado por Dutcosky (1996).

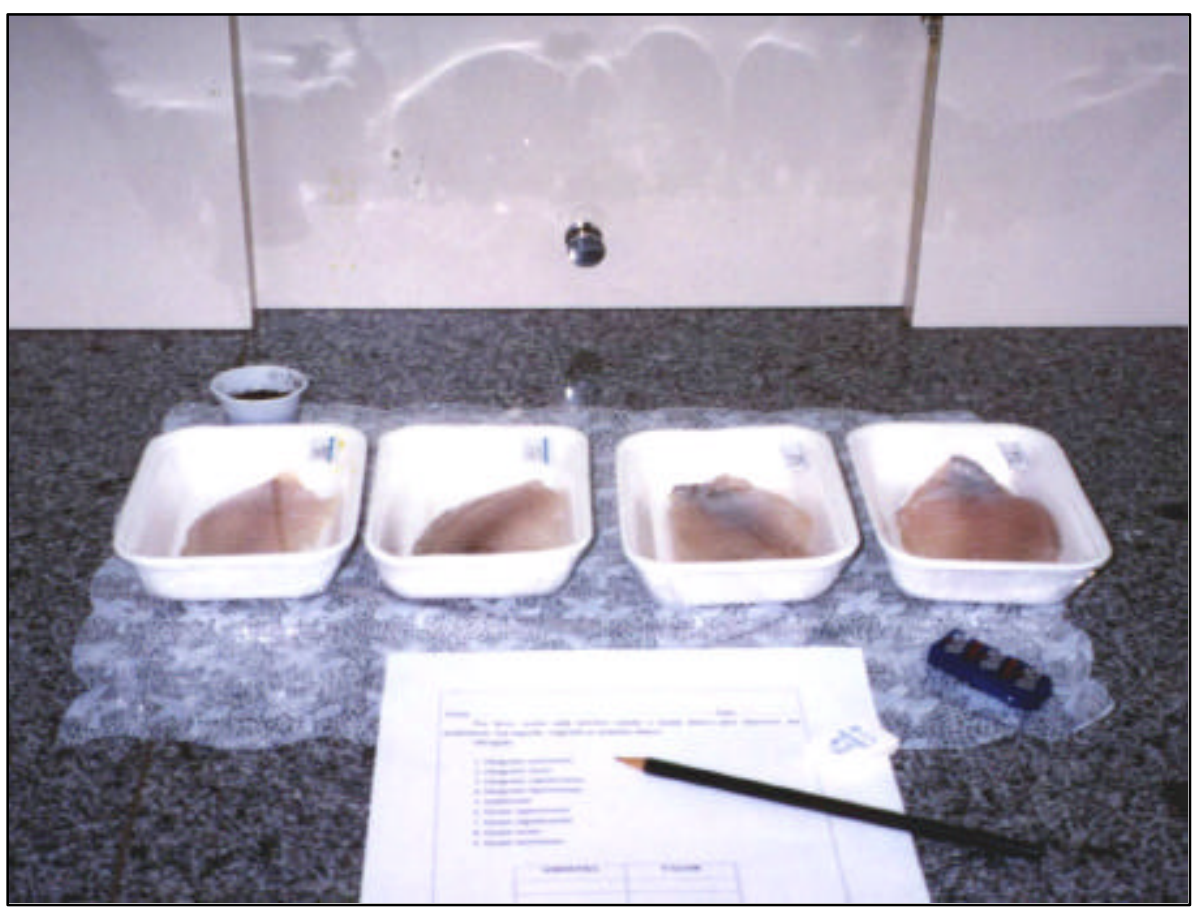

Figura 7- Laboratório de Análise Sensorial a onde foi realizado o teste hedônico. 


\subsection{Delineamento experimental}

Os dados obtidos com as análises físico-químicas foram submetidos à análise de variância, obtendo-se o teste F significativo ao nível de 5\%; prosseguiu-se a análise estatística com o teste de Tukey $(\alpha=0,05)$. Todas as análises foram realizadas pelo SAS (1988). Já os dados obtidos com a análise sensorial foram submetidos à analise de variância univariada e com aplicação do teste F. A análise estatística teve continuidade quando o teste $\mathrm{F}$ foi significativo ao nível de $5 \%$ de probabilidade, através do teste de Tukey. Para a análise estatística utilizou-se o programa SANEST (Pimentel-Gomes, 1990).

Foram realizados 2 ensaios independentes, sendo que em ambos, o delineamento experimental dos resultados das análises físico-químicas, utilizado foi inteiramente ao acaso com os tratamentos dispostos no esquema fatorial, no primeiro 4 x 3 , referentes a 4 doses de radiação $(0,0,1,0,2,2$ e 5,0 kGy) e 3 períodos de armazenamento (1, 20 e 30 dias). Na análise do perfil de aminoácidos, o delineamento experimental utilizado foi o inteiramente ao acaso com os tratamentos dispostos no esquema fatorial $4 \times 2$, referentes a 4 doses de radiação $(0,0,1,0,2,2$ e 5,0 kGy) e 2 períodos de armazenamento (1 e 20 dias $)$ com 3 repetições.

O delineamento experimental realizado para a análise de TBARS, foi inteiramente ao acaso com os tratamentos dispostos no esquema fatorial $4 \times 2$, referentes a 4 doses de radiação $(0,0,1,0,2,2$ e 5,0 kGy) e 2 períodos de armazenamento (1 e 20 dias) com 3 repetições. 
Quanto ao delineamento experimental, dos resultados obtidos com a análise sensorial, foram inteiramente casualisados, sendo 4 tratamentos no primeiro período (doses $0 ; 1,0 ; 2,2 \mathrm{e}$ 5,0 kGy); 3 tratamentos no segundo período (doses 1,0; 2,2 e 5,0 kGy) e 2 tratamentos no terceiro período (doses 2,2 e 5,0 kGy), com 26 repetições para cada tratamento, constituindo cada repetição um provador. 


\section{RESULTADOS E DISCUSSÃO}

\subsection{Composição centesimal}

Os resultados referentes à composição centesimal dos peixes analisados em matéria seca, irradiados e não irradiados, refrigerados e armazenados, são mostrados na Tabela 4.

Tabela 4- Composição centesimal (g/100g de matéria seca) dos peixes não irradiados e irradiados, segundo o tempo de armazenamento.

\begin{tabular}{|c|c|c|c|c|c|c|c|c|c|c|c|c|c|c|c|c|}
\hline \multicolumn{17}{|c|}{ Dose (kGy) / Período } \\
\hline & \multicolumn{4}{|c|}{ Umidade } & \multicolumn{5}{|c|}{ Proteína } & \multicolumn{4}{|c|}{ Lipídeos } & \multicolumn{3}{|c|}{ Cinza } \\
\hline & NI & 1,0 & 2,2 & 5,0 & $\mathrm{NI}$ & 1,0 & 2,2 & 5,0 & NI & 1,0 & 2,2 & 5,0 & NI & 1,0 & 2,2 & 5,0 \\
\hline $1^{\circ}$ dia & 78,0 & 76,5 & 74,6 & 77,5 & 11,0 & 11,9 & 10,4 & 12,0 & 18,3 & 13,5 & 13,3 & 10,1 & 2,0 & 2,2 & 2,0 & 2,1 \\
\hline $20^{\circ} \mathrm{dia}$ & 60,1 & 75,4 & 74,9 & 73,8 & 12,7 & 13,7 & 13,7 & 12,1 & 28,4 & 18,1 & 16,5 & 15,0 & 2,7 & 2,8 & 2,5 & 2,0 \\
\hline $30^{\circ} \mathrm{dia}$ & 69,6 & 72,2 & 75,8 & 75,8 & 14,1 & 15,4 & 15,0 & 12,3 & 30,1 & 14,4 & 24,9 & 14,0 & 3,0 & 3,5 & 2,4 & 2,1 \\
\hline
\end{tabular}

NI pescado não irradiado.

A umidade manteve-se entre 72,2 a 77,5\% para as doses de 1,0; 2,2 e 5,0 kGy até o $30^{\circ}$ dia, sob armazenamento refrigerado, enquanto para a amostra não irradiada a amostra foi perdendo umidade conforme o tempo de armazenamento. De acordo Caúla et 
al. (2000); Contreras-Gusman (1994); Ferreira (1987); Finne (1980) a porcentagem de umidade para o peixe in natura varia de 76 a $81 \%$, estando de acordo os resultados obtidos.

Segundo Beirão et al. (2000) a composição da parte comestível de peixes, crustáceos e moluscos varia entre 70 e $85 \%$ de umidade, 20 a $25 \%$ de proteína, 1 a $10 \%$ de lipídeos e 1 a 1,5\% de cinza ou minerais. Porém, esta composição é altamente variável de espécie para espécie de peixe, bem como, conforme a sazonalidade, idade, parte do corpo, pré ou pósdesova e as condições nutricionais.

Stansby (1951) discute a variação estacional do teor de lipídeos encontrado em cavala (Scomberomorous spp.), variando entre $3,9 \%$ a $19,2 \%$, os quais aumentam de abril a agosto, decrescendo até novembro, porém oscilando entre agosto e novembro. O autor concluiu, que o pescado apresenta oscilações de lipídeos conforme a idade, ou seja, animais adultos apresentam maior teor de gordura.

Natarajan \& Sreenivasan (1961) após análise de trinta e seis espécies de pescado de água doce, verificaram que a composição química também varia amplamente entre as espécies, entre indivíduos e de acordo com a estação do ano. Os autores encontraram teores de umidade entre 67,90 e 83,60\%, proteína bruta entre 13,50 e 19,40\%, lipídeos entre 0,17 e $10,10 \%$ e cinza entre 0,81 e $1,95 \%$, sendo que nos peixes analisados inteiros, o teor de cinza atingiu, $5,14 \%$.

Segundo Sales \& Sales (1990) o conhecimento quantitativo da composição química dos músculos de peixes de interesse comercial é de grande importância para a formulação de uma dieta apropriada, como também na definição de procedimentos técnicos para as 
indústrias de processamento de pescado. É importante ressaltar que a composição química do pescado pode afetar o tipo de processamento a ser utilizado, o sabor, a textura e a estabilidade à oxidação da gordura, seja pelo aumento da insaturação ou pela variação dos antioxidantes naturais. De acordo com Contreras-Gusmán (1994) esta variação é afetada pela idade do peixe, tamanho, sexo e desenvolvimento gonadal, estação do ano, regime alimentar e local de captura.

A quantidade de proteína bruta extraída dos peixes analisados apresentou uma tendência crescente, todavia, as quantidades citadas em literatura variam de 15 a $20 \%$ para peixes in natura, analisados inteiros, ou seja, apenas eviscerados. As doses 1 e 2,2 kGy, apresentaram valores crescentes de proteína bruta, conforme o tempo de armazenamento, sendo que a média dos teores esteve entre 11,9 a 15,4g/100g, para dose $1 \mathrm{kGy}$ e, 10,4 a $15,0 \mathrm{~g} / 100 \mathrm{~g}$, para dose $2,2 \mathrm{kGy}$, para o dia zero e $30^{\circ}$ dia de armazenamento refrigerado. A amostra irradiada a 5 kGy não apresentou tal tendência, mantendo-se entre 12,0 a 12,3g/100g em média, no mesmo período. As amostras não irradiadas apresentaram valores totais crescentes durante o armazenamento relacionando-se com os valores obtidos de nitrogênio não protéico que apresentaram tendência de aumento, conforme o tempo de armazenamento. As alterações da parcela de umidade estão associadas à perda de qualidade do produto e a irradiação preserva as características físicas do produto mantendo-o de acordo com as características de um produto in natura.

É oportuno salientar que existem diferenças na composição lipídica das gorduras extraídas de maneira exaustiva, com solventes orgânicos, das gorduras obtidas por prensagem 
da carne cozida, sendo que o extrato obtido por solvente contém todas as classes de lipídeos de maneira quantitativa, enquanto que o óleo industrial (cozido) contém, principalmente, triacilgliceróis dos depósitos gordurosos e uma porcentagem pequena de lipídeos das membranas celulares (Contreras-Gusmán, 1994).

Os resultados obtidos de lipídeos nesta pesquisa, mostraram valores crescentes, com exceção da amostra irradiada a 5,0 kGy, que manteve-se mais estável, apresentando valores em torno de 10,1; 15,0 e 14,0 g/100g, durante as análises nos dias 1,20 e 30 dias, respectivamente, sob refrigeração.

\subsection{Bases nitrogenadas voláteis totais}

Utilizou-se o método de Lucke e Geidel conforme Pregnolato \& Pregnolato (1985), para determinação de bases nitrogenadas voláteis totais (BNVT) ou bases voláteis totais (BVT), que consiste na destilação direta do músculo triturado, adicionado de $\mathrm{MgO}$ e água destilada para formar o tampão com $\mathrm{pH}$, em torno de 9,8. Todavia, existem controvérsias quanto a destilação direta do músculo triturado, pois o aquecimento das proteínas, em meio alcalino, libera amônia por hidrólise das amidas e, possivelmente, por desaminases no período em que a temperatura começa a subir (Contreras-Gusmán, 1994). Na Figura 8, pode ser observado os valores de BNVT, no pescado irradiado e não irradiado armazenado sob refrigeração.

Sikorski et al. (1994) discutem a análise de BNVT, como indicadora de possíveis

alterações, uma vez que dentro desta denominação genérica, encontram-se diferentes 
substâncias como amônia, trimetilamina, dimetilamina, etilamina, monometilamina, putrescina, cadaverina e espermidina, sendo que, quantitativamente as maiores alterações químicas associadas com a deterioração são devidas à produção de trimetilimina e amônia.

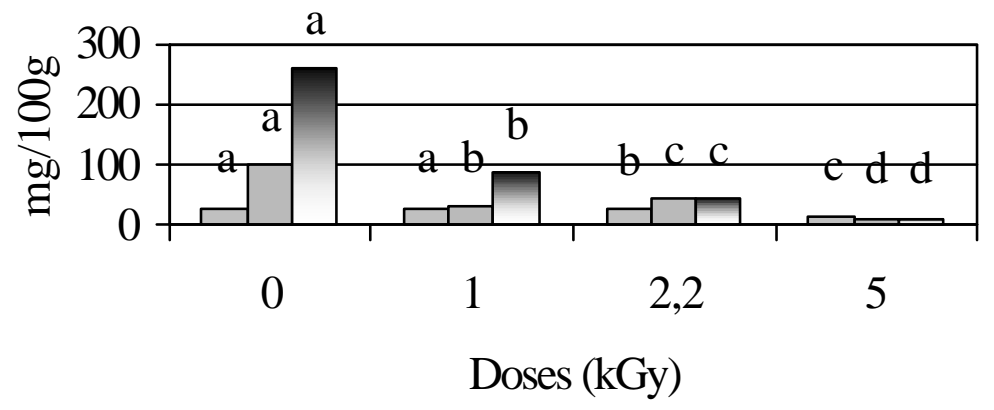

$\square$ dia $\square 20$ dia $\square 30$ dia

Figura 8 - Bases nitrogenadas voláteis totais, em matéria úmida, do pescado irradiado e não irradiado, conforme o tempo de armazenamento. (Médias seguidas de letras distintas diferiram entre si $(\mathrm{p}<0,05)$.

Notou-se que os teores de bases nitrogenadas voláteis totais diferiram grandemente nos peixes não irradiados para os irradiados, a partir do $20^{\circ}$ dia de análise, uma vez que a amostra não irradiada apresentava alterações sensoriais marcantes neste período; já as amostras irradiadas não apresentaram tais características. Os teores encontrados para a amostra não irradiada, estavam entre 27,40; 98,23 e 258,56 mg/100g para os períodos 1, 20 e 30 dias armazenados sob refrigeração. Já as amostras irradiadas apresentaram teores entre 
27,66; 30,07 e 86,83mg/100g; e 24,80, 43,0 e 44,73mg/100g para as amostras irradiadas a 1,0 e 2,2 kGy, nos mesmos períodos. Os resultados obtidos para a amostra irradiada a 5 kGy, mostraram-se mais estáveis, sendo 16,20; 11,57 e 10,17mg/100g nos períodos já mencionados.

Morga (1975) discute que as bases voláteis ocorrem no músculo do pescado devido ao desdobramento das proteínas, por ação enzimática e bacteriana, dando como produtos finais aminas, situando-se entre estas, substâncias voláteis simples. Estas aminas aumentam progressivamente com a deterioração, sendo determinadas no tecido muscular sob a forma de bases voláteis totais.

A partir do momento da captura, o pescado começa a perder o seu aroma característico, e esta é a primeira alteração que deve ser relacionada propriamente com o frescor. Ao longo da estocagem em gelo, o conteúdo das bases nitrogenadas voláteis aumenta progressivamente em função dos processos enzimáticos e microbianos, sendo assim, útil na avaliação do frescor e da deterioração do pescado (Araújo et al., 2000; Shewan, 1961).

Frazier (1976) informa que há muito se busca um sistema prático para determinar a qualidade do pescado, sendo utilizados métodos baseados na produção de trimetilamina e determinação de ácidos e bases voláteis, $\mathrm{pH}$, ácido sulfídrico, amônia, entre outros. Pregnolatto et al. (1985) estabelecem que, além da inspeção em relação às características sensoriais do pescado oferecido ao consumidor, todas estas determinações devem constar.

Apesar da determinação de BNVT ser um dos métodos químicos mais empregados para a avaliação do frescor do pescado, existem controvérsias entre alguns autores. Segundo 
Botelho (1970) citado por Sales et al. (1988), dentre os alimentos cárneos, o pescado é o que se decompõe mais rapidamente, devido a sua constituição pobre em tecido conjuntivo, como também a característica especial do tecido muscular, que tem o pH aumentado após a morte.

De acordo com o Regulamento de Inspeção Industrial e Sanitária de Produtos de Origem Animal - RIISPOA (Brasil, 1976), o limite de BNVT para pescado é de $30 \mathrm{mg} / 100 \mathrm{~g}$ todavia, torna-se inviável estabelecer tal parâmetro para todas as espécies de pescado sem conhecer a composição do produto, uma vez que, o cação (Prionace glauca) estudado por Mujica (1999) apresentou teores elevados de substâncias nitrogenadas não protéicas (NNP), particularmente uréia e amônia, resultantes de decomposições protéicas, o que leva ao aumento de BNVT rapidamente, não significando necessariamente, que o pescado esteja em processo avançado de deterioração.

Segundo Ogawa \& Maia (1999), nos peixes em excelente estado de frescor, o teor de BNVT atinge 5 a $10 \mathrm{mg} / 100 \mathrm{~g}$ de carne, e peixes com frescor razoável podem atingir até 15 a $25 \mathrm{mg} / 100 \mathrm{~g}$ de carne. Portanto, somente as amostras irradiadas com 5 kGy apresentaram valores de bases voláteis totais até $25 \mathrm{mg} / 100 \mathrm{~g}$, ou seja, dentro do limite de frescor do peixe conforme o armazenamento a 1, 20 e 30 dias sob refrigeração. Segundo Kuaye (1982) um valor próximo de 30mg tem mostrado ser compatível com os limites de aceitação sensorial e contagem de microrganismos de muitas espécies, levando alguns países, como o Japão, Austrália, Argentina, Brasil, Alemanha, a adotarem oficialmente este valor como máximo para a comercialização. 
Segundo Contreras-Gusmán (1994) após a morte, o aumento de amônia pode-se originar dos seguintes mecanismos: ação das aminoidrolases sobre nucleotídeos; desaminação de aminoácidos por microrganismos ou hidrólise da uréia pela urease. A amônia derivada destes compostos é produzida logo após a captura e em alguns casos no esforço anterior à captura. Uchiyama ${ }^{3}$ et al. citados por Contreras-Gusmán (1994) verificam que a soma dos produtos de degradação do ATP no charuteiro (Seriola quinqueridata) encontram-se entre 660 e $1050 \mu$ moles por $100 \mathrm{~g}$, e que as desaminações seqüenciadas produzem de 9,2 a 14,7 mg de nitrogênio/ 100g, sendo que este valor coincide com as BNVT determinadas, no presente estudo, nos 4 primeiros dias de estocagem sob refrigeração, concluindo-se que esta amônia não é um produto de decomposição, mas sim da evolução do frescor bioquímico. Todavia, a partir do pós-rigor, a amônia gerada pela atividade microbiana soma-se à produzida nesta fase e, por isso, observa-se um aumento no teor de amônia.

Um aumento inicial da amônia pode ser contrabalançado inicialmente pela lixiviação, particularmente se a área de exposição for muito grande (peixes, filés, postas); porém após alguns dias o aumento torna-se notório e, geralmente, coincide com o aumento de $\mathrm{pH}$. Quanto mais o meio fica alcalino, mais favorece a atividade das desaminases, cujo pH, está próximo a 8,5 (Cobb III et al., 1974; Yeh et al., 1978). Nestas condições, o teor de amônia eleva-se abruptamente em um

${ }^{3}$ UCHIYAMA, H.; EHIRA,S.; KOBAYASHI, H.; SHIMIZU, W. Significance in measuring volatile base and trimethylamine nitrogen and nucleotides in fish muscle as indices of freshness of fish. 
período de 6 a 8 dias decorrente da degradação de aminoácidos (Contreras-Gusmán, 1994).

Souza et al. (2000) avaliaram o desenvolvimento dos níveis de BNVT em músculos de pescado oriundos de piscicultura, em especial o pacu ( armazenados sob refrigeração por até 24 horas após o abate. Notou-se que houve um incremento do nível de BNVT nos intervalos de tempo de 8; 12; 16; 20 e 24 horas, da ordem de 21,$36 ; 24,24 ; 28,99 ; 30,02$ e 32,34 mg/100g de músculos, respectivamente; sugerindo que tal comportamento deve-se ao elevado grau de estresse durante a captura em redes de arraste, o que provoca a diminuição do teor de glicogênio muscular, aumentando o pH.

\subsection{Nitrogênio não-protéico}

Os resultados obtidos para nitrogênio não-protéico, encontram-se na Figura 9 para amostra irradiada e não irradiada.

De acordo com Sikorski et al. (1994), o metabolismo destes compostos é o principal responsável pela perda gradual de frescor e da evidência de sinais de decomposição, particularmente pela decomposição de alguns componentes que afetam fortemente o aroma do pescado fresco, e com formação de compostos voláteis. 


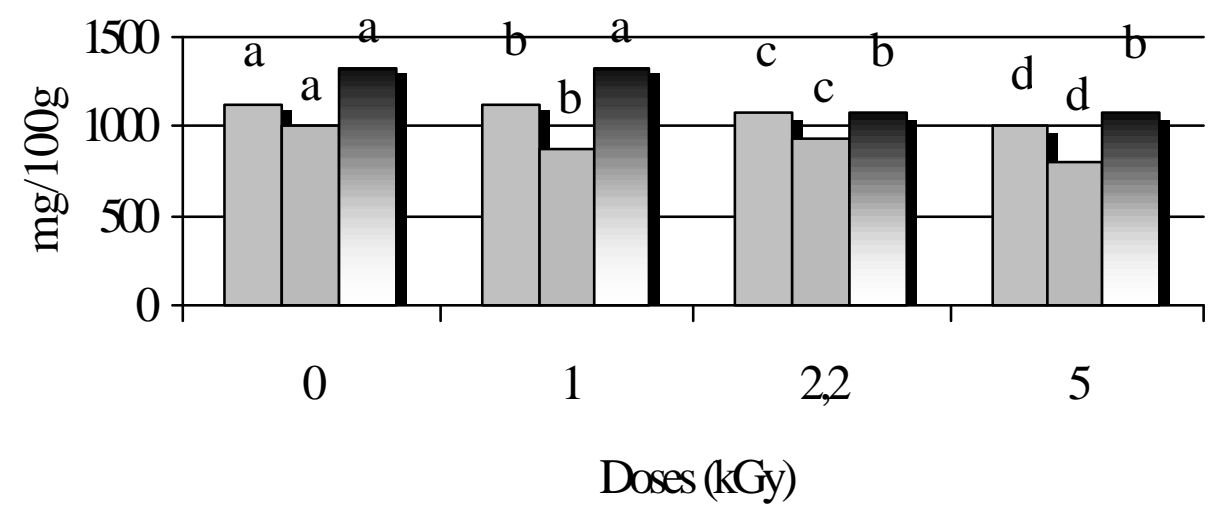

\section{$\square 1$ dia $\square 20$ dias $\square 30$ dias}

Figura 9- Nitrogênio não protéico do pescado não irradiado e irradiado em matéria seca, segundo o tempo de armazenamento. (Médias seguidas de letras distintas diferiram entre si $(p<0,05)$.

A amostra irradiada com 5 kGy apresentou um total de 800,0 e 1.066,6 mg/100g de NNP aos 20 e 30 dias de armazenamento, respectivamente. Tais valores diferem da amostra não irradiada, que apresentou 1.000 e $1.333,3 \mathrm{mg} / 100 \mathrm{~g}$ de NNP nos mesmos períodos. Portanto, a dose de 5 kGy foi mais efetiva segundo a determinação de NNP.

O pescado é um produto que se decompõe rapidamente devido às suas características físico-químicas, favorecendo o desenvolvimento microbiano e atividades enzimáticas. Os compostos nitrogenados não protéicos (NNP) nos músculos de pescado são constituídos das células do plasma e do fluido intercelular (Ludorff \& Meyer, 1978; Sikorski et al. 1994). Eles são passíveis de pronta extração se os músculos foram tratados com água. Desta forma, quando instalam-se alterações pós-morte, tem-se um aumento nos níveis de substâncias 
nitrogenadas, principalmente as não protéicas, ou seja, bases nitrogenadas, aminoácidos livres, amidas, uréia e derivados guanídinicos, imidazólicos e purínicos (Araújo et al. (2000); Sikorski et al. (1994), ocorre a rápida ação de microrganismos endo e exógenos e o aparecimento de substâncias nitrogenadas voláteis e redutoras voláteis, o pH se eleva devido ao desequilíbrio oxi-redutor, sendo que os peixes elasmobrânquios ou cartilaginosos (cações e raias) apresentam teores elevados de NNP, aproximadamente $1.280 \mathrm{mg} / 100 \mathrm{~g}$ (Konosu \& Yamaguchi, 1982).

Ludorff \& Meyer (1978) destacam que os primeiros nutrientes a serem utilizados pelos microrganismos no músculo do pescado, são os compostos nitrogenados não protéicos (NNP), e após esgotar esses substratos, as proteases microbianas geram oligopeptídeos e aminoácidos livres como fonte de suprimento para o seu desenvolvimento.

\section{$4.4 \mathrm{pH}$}

Os resultados obtidos nas análises de pH para o pescado não irradiado e irradiado podem ser observados na Figura 10.

O rigor mortis é caracterizado pela combinação da miosina livre com a actina, formando o complexo actomiosina que confere à carne um enrijecimento e uma maior acidez, com pH em torno de 6,5. A duração do rigor mortis é variável, pois depende do manejo, captura, higiene e temperatura, bem como a acidez característica que esta fase exerce, controla a ação microbiana e enzimática. 


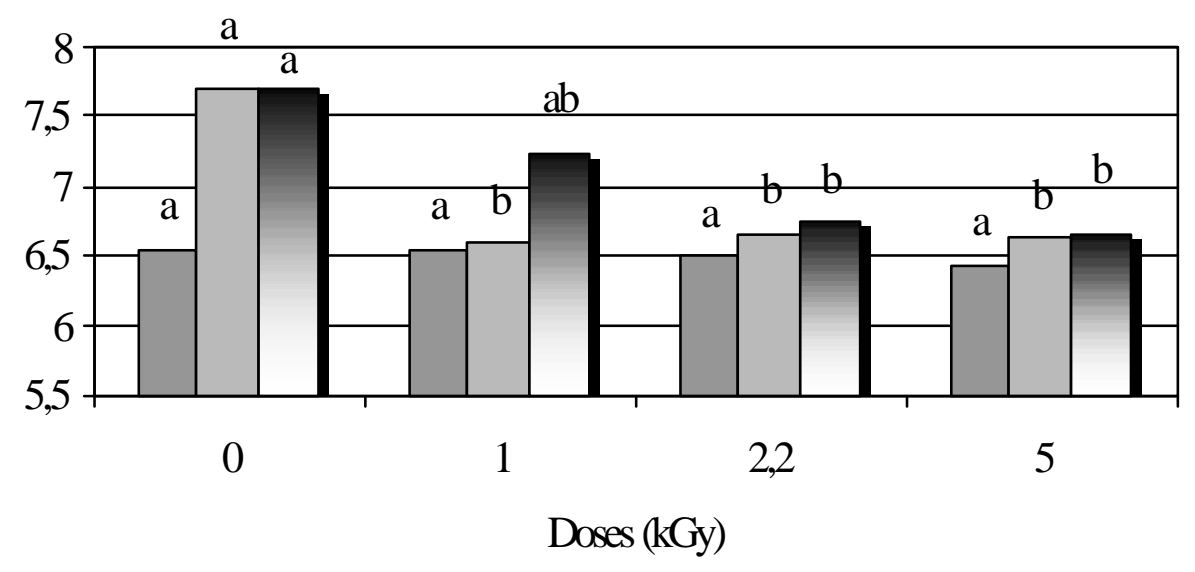

$\square$ 1dia $\square 20$ dias $\square 30$ dias

Figura 10 - Valores de pH do pescado não irradiado e irradiado, segundo o tempo de armazenamento. (Médias seguidas de letras distintas diferiram entre si $(\mathrm{p}<0,05)$.

Os valores encontrados mostraram que para as amostras irradiadas com 1,0 e 2,2 kGy, o pH foi de 6,5 e 6,6 até o $20^{\circ}$ dia sob refrigeração, enquanto para a amostra não irradiada, houve um aumento considerável, por volta de 7,7 no mesmo período, possivelmente devido ao desenvolvimento de compostos nitrogenados, decorrentes da decomposição química e microbiológica. Segundo o Decreto - Lei n. ${ }^{\circ}$ 30.691, artigo 44 do Regulamento de Inspeção Industrial e Sanitária de Produtos de Origem Animal - RIISPOA (Brasil, 1952), os limites máximos de $\mathrm{pH}$ da carne de pescado, que devem estar entre 6,5 a 6,8, nas regiões internas e externas da carne, respectivamente. A amostra irradiada a $5 \mathrm{kGy}$ apresentou um $\mathrm{pH}$, em torno de 6,6 aos 20 e 30 dias de armazenamento, estando de acordo com a legislação. De acordo com Mujica (1999), filés de cação armazenados a temperaturas de 
$0^{\circ} \mathrm{C}, 4^{\circ} \mathrm{C}$ e $10^{\circ} \mathrm{C}$ por até 12 dias, apresentaram valores de $\mathrm{pH}$ crescentes, variando de 6,33 a 9,16, sendo analisados no início do ensaio e após 12 dias, respectivamente.

Neste experimento, foram obtidos valores de $\mathrm{pH}$ abaixo do limite estabelecido pela legislação, para os peixes irradiados até o $20^{\circ}$ dia de armazenamento refrigerado, enquanto o peixe não irradiado já apresentou alterações crescentes de $\mathrm{pH}$ neste mesmo período. Sales et al. (1988) encontraram valores para o pH do músculo de tilápia eviscerada, conservada em gelo, que variaram de 6,70 a 7,08 no primeiro dia, até o $20^{\circ}$ dia de estocagem, sendo que a elevação do pH no músculo pode ter sido resultante da autólise e posterior contaminação bacteriana causada pela maior concentração bacteriana.

Sales et al. (1988) encontraram valores para o pH do músculo de tilápia eviscerada, conservada em gelo, que variaram de 6,7 a 7,08 do primeiro dia ao $20^{\circ}$ dia de estocagem, sendo que a elevação do $\mathrm{pH}$ no músculo pode ser resultante da autólise e posterior contaminação bacteriana.

Para Sikorski et al. (1994), o aumento do pH em espécies marinhas pode ser devido ao acúmulo de bases nitrogenadas, tais como trimetilamina, dimetilamina, amônia e algumas bases orgânicas, produzidas pela hidrólise bacteriana de compostos nitrogenados do músculo, e em menor grau, à autólise.

Os resultados de BVT e pH foram correlacionados com as doses de radiação, apresentando correlação positiva de 0,99 para os valores de BVT e pH, ou seja, à medida em que uma variável aumentava com o aumento das doses de radiação, outra variável aumentava na mesma proporção. 
Quanto à correlação entre as variáveis sensoriais e BVT, essa foi negativa $(-0,905)$, ou seja, à medida que os valores de BVT decresciam com o aumento das doses de radiação, as notas dos provadores aumentavam. Fato semelhante ocorreu com os valores de $\mathrm{pH}$ e sensorial, os quais obtiveram correlação negativa $(-0,947)$.

Segundo Kieltzman et al. (1974) os sinais de deterioração do pescado podem ser registrados também por meios físicos, modificações do tipo mecânico, alterações de pH e da condutividade elétrica.

Sales et al. (1988) analisaram o pH de algumas espécies de pescado, sendo 25 peixes eviscerados, os quais foram lavados com água corrente e acondicionados em caixas de isopor, com gelo, em camadas alternadas, na proporção de $25 \mathrm{~kg}$ de gelo para $1 \mathrm{~kg}$ de peixe, além de outro grupo de peixes, a mesma quantidade, inteiros, acondicionados da mesma maneira, por vinte dias. Os valores encontrados para o $\mathrm{pH}$ do músculo de pescado eviscerado, conservado em gelo, variaram de 6,70 a 7,08 para a tilápia ( Oreochromis spp.), 6,78 a 7,95 para o tucunaré (Cichla temensis) e 6,80 a 8,20 para a pescada do Piauí (Cynoscion sp.), enquanto que, para o peixe inteiro submetido ao mesmo tratamento, os valores do $\mathrm{pH}$ tiveram uma variação de 6,80 a 8,25 para a tilápia, 6,82 a 8,47 para o tucunaré e 6,85 a 8,60 para a pescada do Piauí. A elevação do $\mathrm{pH}$ no músculo das tilápias nilóticas foi provavelmente, devida a autólise e posterior contaminação bacteriana, causada pela maior concentração bacteriana, visto que estes indivíduos continham ainda as vísceras. 
Segundo Lahiry et al. (1963) e Tomiyasu \& Zenitani (1957) enquanto avança a deterioração bacteriana, há acúmulo de produtos de natureza básica, tais como trimetilamina, dimetilamina, amônia e algumas bases orgânicas, por isso, os valores de $\mathrm{pH}$ dos músculos do pescado aumentam de forma lenta no início e rapidamente no final da deterioração. Entretanto, mudanças de $\mathrm{pH}$, devido à deterioração bacteriana, diferem marcadamente com a variedade do pescado e da época do ano.

\subsection{Análises microbiológicas}

Nas amostras analisadas, tanto as não irradiadas como as irradiadas não apresentaram Salmonella e $S$. aureus (<10 UFC/g), estando perfeitamente enquadradas nos padrões legais vigentes.

$\mathrm{Na}$ análise para $S$. aureus, com a utilização do meio BPA, detectou-se o desenvolvimento de colônias bacterianas de coloração preta e cinza nas amostras não irradiadas, aos 20 dias de armazenamento refrigerado, característico de bactérias cocos e bastonetes, enquanto nas amostras irradiadas este fato não ocorreu. Portanto, a irradiação foi efetiva também para tais microrganismos.

Os resultados das análises microbiológicas para coliformes totais, coliformes fecais e psicrotrófilos, podem ser observados nas Tabelas 5, 6 e 7, respectivamente. 
Tabela 5- Coliformes totais em pescado não irradiado e irradiado, segundo os períodos de armazenamento sob refrigeração.

\begin{tabular}{ccccc}
\hline & \multicolumn{4}{c}{ NMP de Coliformes totais/g de amostra * Doses (kGy) } \\
Armazenamento(dias) & 0 & 1 & 2,2 & 5 \\
\hline Início & $1,81 \times 10^{5}$ & $2,5 \times 10^{2}$ & $0,2 \times 10^{2}$ & $* *$ \\
20 & $1,84 \times 10^{5}$ & $6,0 \times 10^{3}$ & $2,8 \times 10^{2}$ & $* *$ \\
30 & $7,4 \times 10^{5}$ & $1,45 \times 10^{5}$ & $7,4 \times 10^{3}$ & $* *$ \\
\hline
\end{tabular}

* Média de análises realizadas em duplicata.

** Não desenvolvimento de coliformes totais.

Tabela 6- E. coli em pescado não irradiado e irradiado, segundo os períodos de armazenamento sob refrigeração.

\begin{tabular}{ccccc}
\hline & \multicolumn{4}{c}{ NMP de E. coli / g de amostra */ Doses (kGy) } \\
Armazenamento(dias) & 0 & 1 & 2,2 & 5 \\
\hline Início & $1,12 \times 10^{4}$ & $* *$ & $* *$ & $* *$ \\
20 & $1,34 \times 10^{4}$ & $* *$ & $4 \times 10^{1}$ & $* *$ \\
30 & $7,4 \times 10^{4}$ & $* *$ & $4 \times 10^{1}$ & $* *$ \\
\hline
\end{tabular}

* Médias de análises realizadas em duplicata.

** Não desenvolvimento de coliformes fecais. 
Tabela 7- Microrganismos psicrotrófilos nas amostras de pescado não irradiado e irradiado, segundo os períodos de armazenamento sob refrigeração.

\begin{tabular}{ccccc}
\hline & \multicolumn{4}{c}{ Psicrotrófilos UFC/ g amostra / Doses (kGy) } \\
Armazenamento(dias) & 0 & 1 & 2,2 & 5 \\
\hline 20 & $5,0 \times 10^{4}$ & $3,7 \times 10^{4}$ & $4,810^{4}$ & $*$ \\
& $4,3 \times 10^{5}$ & $5,0 \times 10^{5}$ & $3,3 \times 10^{5}$ & $*$ \\
& $5,0 \times 10^{6}$ & $4,1 \times 10^{6}$ & $3,2 \times 10^{6}$ & $*$ \\
30 & $4,7 \times 10^{4}$ & $4,2 \times 10^{4}$ & $4,0 \times 10^{4}$ & $*$ \\
& $3,5 \times 10^{5}$ & $3,3 \times 10^{5}$ & $3,1 \times 10^{5}$ & $*$ \\
& $3,5 \times 10^{6}$ & $2,9 \times 10^{6}$ & $2,7 \times 10^{6}$ & $*$ \\
\hline
\end{tabular}

* Não houve desenvolvimento de psicrotrófilos no período de análise.

Dentre os resultados obtidos conclui-se que a irradiação foi efetiva para as doses de 2,2 e 5 kGy na análise de coliformes totais, porém pode-se observar, que a dose 2,2 kGy não apresentou tal efetividade para coliformes fecais (E. coli). Na análise de psicrotrófilos, foi observado que as doses de 1 e 2,2 kGy mantiveram-se dentro dos padrões estabelecidos pela legislação brasileira vigente, e a amostra irradiada com $5 \mathrm{kGy}$, apresentou segurança microbiológica mesmo após 20 dias de armazenamento refrigerado. Todas as determinações microbiológicas realizadas nas amostras não irradiadas, durante os períodos de armazenamento, mostraram resultados crescentes, acima dos padrões estabelecidos. Portanto, pode-se concluir que a irradiação mostrou-se efetiva, especialmente a irradiação com 5 kGy, em todas as análises microbiológicas. 
O Compêndio de Normas e Padrões para Alimentos citados pela Associação Brasileira das Indústrias de Alimentação (1996), estabelece como padrão microbiológico para pescado, a contagem padrão em placas de no máximo $10^{6} \mathrm{UFC} / \mathrm{g}$. A Portaria n. ${ }^{\circ} 451$ de 19/09/97 do Ministério da Saúde/SVS (1997), fixa os seguintes padrões microbiológicos para pescado in natura e refrigerado: Salmonella : ausência em $25 \mathrm{~g}$; Coliformes fecais : máximo de $10^{2} / \mathrm{g} ;$ S. aureus : máximo de $10^{3} / \mathrm{g}$.

Ahmed et al. (1997) analisaram a influência da radiação gama, utilizando uma dose de 2 e 3 kGy para estender a vida útil, sob refrigeração, do pescado inteiro e do eviscerado, analisando os microrganismos psicrotrófilos por até 25 dias. Os resultados iniciais estavam em torno de $8 \times 10^{5} / \mathrm{g}$ de pescado para as amostras irradiadas e não irradiadas. Após 5 dias sob armazenamento refrigerado, as amostras não irradiadas apresentaram 9x10 /g enquanto as irradiadas mostraram valores em torno de 9,5x10 /g após 15 dias de armazenamento.

Wagner (2000) destaca as doses de radiação necessárias para reduzir a população inicial de bactérias patógenas em $90 \%$ do produto (valor “D”). Entre os valores estão: 0,18 a 0,24 kGy para desinfecção de Compilobacter jejuni, 0,556 kGy para Clostridium perfringes, 0,25 a 0,45 kGy para Escherichia coli 0157:H7, 0,4 a 0,64 kGy Listeria monocytogenes, 0,48 a 0,7 kGy para Salmonella, 0,45 kGy para Staphylococcus aureus, 0,4 a 0,7 kGy para Tripanosoma gondii e 0,3 a 0,6 kGy para T. spiralsi.

Ferreira (1987) analisou nove amostras de pescado, dentre as quais encontraram-se

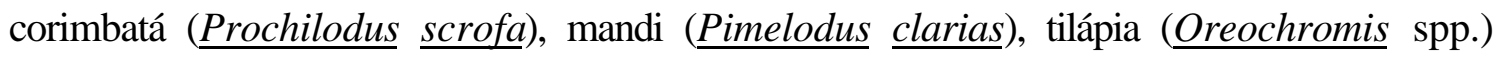
entre outros, sendo que 44,4\% apresentaram contagens de microrganismos psicrotrófilos da 
ordem de $10^{5} \mathrm{UFC} / \mathrm{g}$, e 55,5\% da ordem de $10^{4} \mathrm{UFC} / \mathrm{g}$. Para a tilápia, a contagem total de psicrotrófilos, variou entre $8,3 \times 10^{4}$ a $1,8 \times 10^{5} \mathrm{UFC} / \mathrm{g}$.

A entrada de microrganismos na carne do pescado e a decomposição gradual das substâncias nitrogenadas começam quase que simultaneamente à autólise; a velocidade e intensidade porém, dependem da temperatura de estocagem. Se o pescado é mantido sob gelo, ocorre inibição da atividade bacteriana e o processo de autólise é mais intenso que a decomposição bacteriana. Já quando a temperatura é maior, a decomposição bacteriana predomina (Beirão et al., 2000).

Segundo Gelli et al. (1979), a legislação brasileira tolera 10.000 coliformes fecais/100g de ostras, o que representa uma elevada quantidade de microrganismos quando comparado aos padrões microbiológicos de outros países, já que segundo Goepfert (1976), o padrão americano estabeleceu 10 bactérias/g de produto cárneo. Para microrganismos psicrotróficos, a legislação brasileira (ICMSF, 1984) estabelece limites máximos recomendáveis para o pescado fresco refrigerado, de $10^{6} \mathrm{UFC} / \mathrm{g}$ ou $\mathrm{cm}^{2}$.

De acordo com Shewan et al. citados por Góes (1987) as bactérias predominantes no pescado fresco, bem como em estado deteriorado, são psicrotrófilas Gram negativas, especialmente quando o pescado encontra-se armazenado à temperatura próxima a $0^{\circ} \mathrm{C}$; há um aumento no número de Pseudomonas, que se desenvolvem à temperatura de $-5^{\circ} \mathrm{C}$. Portanto, independente da flora inicial de contaminação, a flora final de deterioração consistirá desta bactéria. 
Hoffmann et al. (1999) analisaram 11 amostras de peixes obtidos do comércio varejista de São José do Rio Preto (SP), devidamente acondicionadas em sacos plásticos, para as determinações da qualidade higiênico-sanitária dos mesmos. Dentre as análises microbiológicas, obtiveram maior destaque as contagens de Vibrio parahaemolyticus, Staphylococcus aureus, determinação do número mais provável de coliformes totais e fecais, pesquisa de Escherichia coli e Salmonella. Os resultados encontrados com relação a $V$. parahaemolyticus mostraram que onze amostras analisadas (100\%) apresentaram o mesmo resultado, $<10^{3} \mathrm{UFC} / \mathrm{g}$ estando portanto, em acordo com o padrão estabelecido (máximo de $5 \times 10^{3} / \mathrm{g}$ ) na legislação brasileira. Para S. aureus, duas amostras estavam de acordo com o padrão, e nove em desacordo, sendo classificadas como "produto em condições higiênicosanitárias insatisfatórias". Para os coliformes fecais, todas estavam dentro dos padrões, porém em duas amostras encontrou-se a presença de E. coli. Para coliformes totais, houve variação de 4 a >1100 NMP/g. Houve positividade para Salmonella em quatro amostras. Portanto, concluiu-se que os produtos pesqueiros encontravam-se em condição higiênico-sanitária insatisfatória e potencialmente são considerados capazes de causar surtos de toxinfecções alimentares, o que evidencia as condições atuais de comercialização do pescado brasileiro.

\subsection{Substâncias reativas ao ácido tiobarbitúrico (TBARS)}

Na Figura 11, são apresentados os valores médios padrões para o teor de substâncias reagentes ao ácido tiobarbitúrico (TBARS) em filés de tilápia não irradiada e irradiada. 


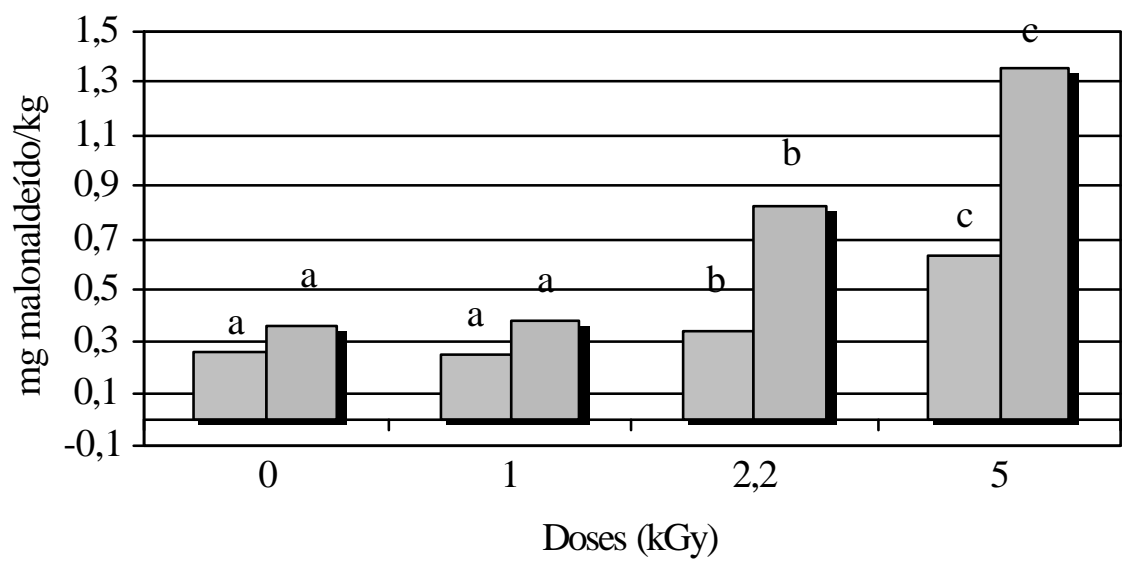

1dia

$\square 20$ dias

Figura 11 - Valores de TBARS do pescado não irradiado e irradiado em matéria úmida, segundo o tempo de armazenamento. (Médias seguidas de letras distintas diferiram entre si $(\mathrm{p}<0,05)$.

As amostras foram analisadas em dois períodos de armazenamento refrigerado, no primeiro dia e no $20^{\circ}$ dia, mantendo os tratamentos. Dentre os valores encontrados de TBARS, a amostra irradiada com a dose de $5 \mathrm{kGy}$ apresentou valores entre 0,63 e 1,36 mg de malonaldeído/kg de amostra, enquando as amostras irradiadas com 1,0 kGy apresentaram valores de 0,25 e 0,38 mg malonaldeído/kg; com 2,2 kGy, 0,34 e 0,83 mg de malonaldeído/kg e a amostra não irradiada, 0,26 e 0,36 mg malonaldeído/kg, durante os mesmos períodos de análise. Segundo Al- Kahtani et al. (1996) o produto pode ser considerado em bom estado, apresentando valores abaixo de 3,0 mg de malonaldeído/kg de amostra. A legislação vigente no Brasil, não apresenta limite máximo para malonaldeído/kg em 
produtos cárneos, sendo que, para o parâmetro citado, todas as amstras apresentaram-se de acordo.

Segundo Torres \& Okani (1997), mais importante que o teor lipídico de um alimento, é a forma como o mesmo se encontra, bem como sua possível participação em doenças crônica-degenerativas, pois o malonaldeído, além de outros produtos de oxidação lipídica, possui relação com a formação de câncer em seres humanos. Um dos métodos mais utilizados, em produtos cárneos, para se avaliar a extensão da estabilidade lipídica é o teste de TBA (ácido 2-tiobarbitúrico) ou TBARS (substâncias reativas ao ácido 2-tiobarbitúrico), sendo que neste teste, o malonaldeído após ser obtido por destilação, reage sob aquecimento com o ácido tiobarbitúrico, produzindo coloração rósea que pode ser medida espectrofotometricamente e comparada com a absorção da curva padrão.

A fração lipídica dos alimentos está relacionada a diversas propriedades organolépticas como aroma, coloração, textura, suculência, estabilidade das proteínas, vida útil sob congelamento e conteúdo calórico (Allen \& Foegeding, 1981).

A oxidação lipídica constitui-se de três fases: iniciação, propagação e terminação, sendo que a primeira etapa está relacionada às condições em que os alimentos estão expostos ou seja, a fontes elevadas de energia ou radiações ionizantes, microondas, radiação ultravioleta e luz visível com fotossensibilizadores. Sabe-se que o início do processo oxidativo decorre da interação de um iniciador com o oxigênio, que uma vez ativado, pode reagir com o ácido graxo insaturado, ocorrendo a retirada de um átomo de hidrogênio do carbono metilênico 
adjacente à ligação dupla cis do ácido graxo insaturado, resultando na formação de radicais alílicos (Kanner, 1994; Sevanian \& Hochstein, 1985).

Sant'Ana \& Fernandes (2000) avaliaram a oxidação lipídica, através dos teores de TBARS, pela metodologia de Wyncke (1970) de filés de pacu (Piaractus $\underline{\text { mesopotamicus })}$ em armazenamento congelado. Foi observado um gradual aumento da oxidação, estando os valores de TBARS em torno de 0,$41 ; 0,62 ; 0,59$ e $1,49 \mu$ de malonaldeído/g de peixe, respectivamente, no início e após 30, 60 e 90 dias de armazenamento.

São inúmeras as consequências nutricionais da oxidação lipídica, dentre elas, destruição parcial dos ácidos graxos insaturados essenciais linoléico e linolênico; destruição parcial de vitaminas lipossolúveis como a vitamina A, carotenóides e tocoferóis; destruição parcial da vitamina C; formação de produtos secundários da oxidação lipídica e compostos de Maillard, capazes de reagir com biomoléculas (especialmente proteínas), diminuindo a absorção destas; irritação da mucosa intestinal por peróxidos, entre outras (Ferrari, 1998).

As reações oxidativas de ácidos graxos dão origem à formação de aldeídos e outros compostos voláteis que conferem odores desagradáveis a produtos cárneos e derivados, e quando em armazenamento, apresentam aroma/sabor de "alimento requentado", bem como promovem a modificação da cor, quando há transformação do pigmento oximioglobina (vermelho-brilhante) em metamioglobina (marrom-acinzentado). Outro aspecto importante, diz respeito a alteração da textura da carne, advinda da oxidação lipídica, uma vez que, esta pode resultar na formação de complexos proteína-lipídio ou provocar cisão de proteínas (Kanner, 
1994). O aldeído mais encontrado como produto de oxidação lipídica é o malonaldeído, produzido durante a autoxidação dos ácidos graxos polinsaturados (Torres \& Okani, 1997).

Luzia et al. (2000) analisaram os teores de TBARS em tilápia (Oreochromis spp.) durante o verão e o inverno, e encontraram em média, 0,235 mg malonaldeído/kg no verão e 0,117 mg malonaldeído/kg no inverno, valores considerados satisfatórios, porém há rancidez incipiente.

A irradiação de alimentos, utilizando altas doses, pode causar aumento nos valores de

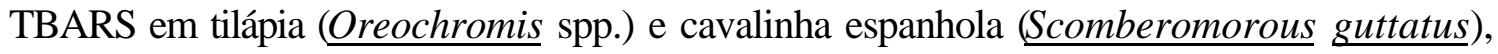
principalmente quando os peixes foram estocados sob baixa temperatura, uma vez que ocorre autoxidação da gordura acelerada pela presença do oxigênio, durante ou após a irradiação (Al-Kahtani et al., 1996; Urbain, 1986).

Ghadi \& Venugopal (1991) analisaram cavala-da-Índia (Rastrelliger kanagurta),

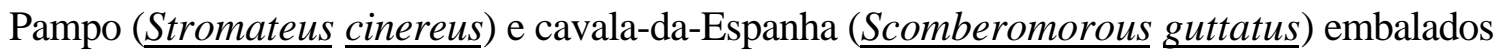
e irradiados sob doses de 0 a 5 kGy e armazenados congelados por até 4 semanas. Dentre os resultados obtidos, notou-se através de análises de TBARS, que houve maior desenvolvimento oxidativo, na pele dos três tipos de pescado; sendo 5,3 a 12,9\% para a cavala-da-Índia, 4,8 a 14,1\% para pampo e 8,3 a 9,4\% para a cavala-da-Espanha, conforme o período de 0 a 4 semanas de armazenamento, respectivamente.

A elevada presença de oxidação na pele do pescado é explicada por Kamat \& Kumta (1972), ocorrendo devido a presença de altas proporções de fosfolipídeos; após um tempo 
de armazenamento tem-se início os processos autolíticos que não são desencadeados, portanto, pela ação da irradiação.

\subsection{Análises nutricionais}

\subsubsection{Aminoácidos}

Utilizou-se como metodologia o Analisador Automático de Aminoácidos, que consta de duas hidrólises para aminoácidos, sendo $\mathrm{LiOH} 4 \mathrm{~N}$ para triptofano por 24 horas a $110^{\circ} \mathrm{C} \pm$ $1^{\circ} \mathrm{C}$ e para as demais, $\mathrm{HCl} 6 \mathrm{~N}$ à mesma temperatura por 22 horas. Após serem submetidos à hidrólise ácida, foram quantificados em analisador de aminoácidos por cromatografia líquida de alta eficiência, porém alguns peptídeos são mais resistentes a hidrólise e só se separam aproximadamente, da ordem de 50 a $70 \%$, em 24 horas a $110^{\circ} \mathrm{C}$, conforme Moore \& Stein (1963).

Geiger (1962) afirma que a composição em aminoácidos de peixes pode variar em função da metodologia, uma vez que a hidrólise geralmente é ineficiente e o cálculo dos teores de aminoácidos é prejudicado pelo nitrogênio não protéico presente na amostra.

Os tratamentos térmicos, como a pasteurização, a esterilização ou a cocção de um alimento protéico, promovem a reação de Maillard, a desnaturação protéica, perdas de aminoácidos sulfurados e formação de $\mathrm{H}_{\mathbf{L}} \mathrm{S}$, como em carnes enlatadas com a formação de $\mathrm{H}_{2} \mathrm{~S}$ que pode levar à formação de sulfetos de ferro e estanho, além do aquecimento provocar alterações nas frações lipídicas, resultando na formação de aromas particulares para cada tipo de carne (Bobbio, 1992). 
Os teores de aminoácidos encontrados nas amostras não irradiadas e irradiadas, armazenadas sob refrigeração por 1 e 20 dias, podem ser observados na Tabela 8.

Tabela 8- Aminoácidos (mg/100g em matéria seca), do peixe não irradiado (NI) e irradiado, segundo o tempo de armazenamento (inicial e 20 dias).

\begin{tabular}{lcccccccc}
\hline Áminoácidos* & \multicolumn{7}{c}{ Doses (kGy) / Tempo de Armazenamento } \\
& NI & NI & $1 \mathrm{kGy}$ & $1 \mathrm{kGy}$ & $2,2 \mathrm{kGy}$ & $2,2 \mathrm{kGy}$ & $5 \mathrm{kGy}$ & $5 \mathrm{kGy}$ \\
\hline Triptofano & 489,6 & 541,6 & 498,7 & 523,1 & 413,1 & 448,8 & 648,7 & 960,8 \\
Lisina & 5436,3 & 4590,2 & 5517,3 & 5904,9 & 4907,0 & 6945,9 & 5322,4 & 3795,8 \\
Histidina & 1656,1 & 1296,5 & 1711,9 & 1834,4 & 1489,5 & 1987,1 & 1449,2 & 1560,0 \\
Arginina & 4588,3 & 4638,8 & 4423,6 & 5332,2 & 3726,2 & 5353,9 & 4069,8 & 3795,8 \\
Ácido Aspártico & 5825,4 & 6177,8 & 6884,7 & 6489,0 & 5813,4 & 8189,4 & 7128,1 & 6514,3 \\
Treonina & 3148,1 & 3023,2 & 3618,2 & 3383,1 & 2920,2 & 3499,7 & 3267,1 & 2984,5 \\
Serina & 2904,3 & 2875,9 & 3281,2 & 3309,6 & 2920,0 & 3531,6 & 3050,2 & 3104,3 \\
Ácido Glutâmico & 7145,6 & 7765,2 & 8196,7 & 7735,1 & 7579,3 & 10493,6 & 10608,9 & 9178,6 \\
Prolina & 3326,9 & 4291,2 & 3518,4 & 3765,6 & 2336,8 & 2891,1 & 3748,4 & 3236,6 \\
Glicina & 4744,8 & 5983,8 & 4983,3 & 5231,6 & 3939,0 & 5382,0 & 5134,5 & 5151,7 \\
Alanina & 4924,8 & 5356,4 & 5668,8 & 5380,0 & 4306,7 & 5536,2 & 4771,2 & 5031,6 \\
1/2 Cistina & 619,5 & 646,1 & 748,3 & 902,6 & 560,8 & 851,2 & 585,6 & 583,8 \\
Valina & 3550,9 & 2605,0 & 4142,3 & 3116,3 & 2310,7 & 2907,4 & 2630,1 & 2031,1 \\
Metionina & 2492,7 & 2100,1 & 2810,1 & 2588,8 & 2247,6 & 2483,8 & 1818,5 & 1732,8 \\
Isoleucina & 3330,0 & 2381,5 & 3753,8 & 2795,5 & 2154,9 & 2847,2 & 2398,6 & 1871,9 \\
Leucina & 5819,0 & 4930,8 & 6497,6 & 5584,5 & 4883,6 & 6232,9 & 4909,2 & 4708,1 \\
Tirosina & 2848,0 & 2207,3 & 3136,7 & 2669,7 & 2413,6 & 2865,2 & 2076,0 & 1922,2 \\
Fenilalanina & 3606,9 & 2869,3 & 3876,6 & 3431,1 & 2927,1 & 3415,5 & 2583,9 & 2237,4 \\
\hline
\end{tabular}

* Média dos resultados obtidos em triplicata de amostras.

De acordo com os resultados do total de aminoácidos obtidos em matéria seca, observou-se que a amostra não irradiada apresentou diminuição de alguns aminoácidos aos 20 dias de armazenamento, dentre eles lisina, histidina, valina, metionina, isoleucina, leucina, 
tirosina e fenilalanina. A amostra irradiada com 1,0 kGy manteve-se mais estável quando comparada às demais, especialmente com os aminoácidos essenciais. A amostra irradiada com 2,2 kGy apresentou resultados crescentes aos 20 dias de armazenamento. A amostra irradiada com 5,0 kGy, apresentou diminuição entre os resultados obtidos aos 20 dias de armanazenamento. A irradiação não é um tratamento que submeta o alimento a alterações de temperatura porém, durante a obtenção da matéria seca, a mesma foi submetida ao aquecimento em estufa a $105^{\circ} \mathrm{C}$, até peso constante, e alguns aminoácidos são menos estáveis ao aquecimento, o que sugere desnaturação em alguns perfis.

Ogawa \& Maia (1999) destacam que as perdas de aminoácidos pode ser oriunda de alterações bioquímicas ou devida à ação da atividade bacteriana sendo assim, o aminoácido isoleucina obtido nesta pesquisa, apresentou-se com valores menores aos 20 dias de armazenamento para todas as amostras devido, provavelmente, à decomposição por descarboxilação, onde as enzimas reagem com aminoácidos do grupo $\mathrm{COOH}$ terminal, formando aminas relativas e $\mathrm{CO}_{2}$. $\mathrm{O}$ aminoácido leucina, também pode ter sofrido descarboxilação nas amostras não irradiadas e irradiadas com 1,0 kGy; como também lisina, apresentando diminuição nas amostras não irrradiadas e irradiadas com 5,0 kGy e tirosina, para as amostras não irradiadas e irradiadas com 1,0 kGy e 5,0 kGy.

As proteínas do pescado são mais instáveis, desnaturando-se mais facilmente que as dos animais terrestres especialmente devido a alterações provocadas por enzimas autolíticas, ação microbiana e reações químicas (Góes, 1987). Quando ocorrem rompimentos entre as ligações carbônicas, são provocadas alterações irreversíveis nas funções das poliestruturas da proteína, 
resultando em alterações na atividade biológica, solubilidade, capacidade de reação com grupos constituintes (resíduos de aminoácidos), alterações no tamanho e na formação de moléculas ou seja, ocorre a desnaturação (Ogawa \& Maia, 1999).

Estudos in vitro mostram que os aminoácidos livres e os aminoácidos protéicos são sensíveis às radiações. Radicais livres formados por radiólises da água reagem com aminoácidos, absorvendo hidrogênio e reduzindo a desaminação. Os radicais formados produzem reações adicionais como por exemplo, descarboxilação e desaminação resultando em amônia e ácido pirúvico, no caso de alanina. Em presença de oxigênio, desaminações oxidativas substitutivas são formadas. Cistina, cisteína e metionina agem como carregadoras e reagem mais com radicais livres do que com cadeias não sulfuradas de aminoácidos alifáticos (Ogawa \& Maia, 1999).

Os aminoácidos aromáticos, como fenilalanina e tirosina reagem com subprodutos da reação de radiólises da água, hidroxilando as cadeias aromáticas da reação principal. Quando a irradiação de compostos protéicos é executada em presença de água, todas estas reações são possíveis de ocorrer, como também com outros macronutrientes (Savagon \& Sreenivasan, s.d.).

Underdal et al. (1976) analisaram o efeito da irradiação sobre aminoácidos de cavala (Scomberomorus spp.), concluindo que a irradiação com doses de esterilização (acima de 20 kGy), não afeta significativamente a composição de aminoácidos do tecido muscular. Entretanto, aminoácidos de cadeia sulfúrica são mais instáveis a este processamento. 
Em pesquisa realizada por Ogawa et al. (2000), a determinação de aminoácidos livres em caranguejo uçá ( $\underline{\text { Ucides }} \underline{\text { cordatus })}$, guaiamum (Cardisoma guanhumi) e aratu ( $\underline{\text { Goniopsis }}$ cruentata), pela metodologia de Spackman et al. (1958), observou-se que os teores de glutamina somados aos de glicina totalizaram, $2.189 \mathrm{mg} / 100 \mathrm{~g}, 2.519 \mathrm{mg} / 100 \mathrm{~g}$ e 2.742 mg/100g, para estas espécies, respectivamente. O conteúdo de prolina variou de 7,5 a 9,0 mg/100g em aratu, 99,0 mg/100g em guaiamum e 133 mg/100g para o uçá. Taurina apresentou valores em torno de $1,7 \mathrm{mg} / 100 \mathrm{~g}$ para o uçá, e 4,8 mg/100g para o aratu.

A decomposição de aminoácidos sulfurosos (cistina, cisteína e metionina) produz sulfitos de hidrogênio e mercaptanas. A natureza da decomposição bacteriana dos aminoácidos depende da composição da microflora e das condições presentes, que estimulam ou não o desenvolvimento do processo de oxidação aeróbica ou redução anaeróbica. Os produtos finais da decomposição bacteriana das proteínas são substâncias inorgânicas (hidrogênio, dióxido de carbono e amônia); compostos sulfurosos e compostos heterocíclicos, entre outros (Beirão et al., 2000).

Maia \& Ogawa (2000) determinaram a composição em aminoácidos de tambaqui (Colossoma $\underline{\text { macropomum })}$, pacu ( ( $\underline{\text { Oreochromis }} \underline{\text { niloticus })}$ e curimbatá ( $\underline{\text { Prochilodus }} \underline{\text { scrofa }})$, sendo que as três primeiras espécies foram coletadas do cativeiro e o curimbatá do rio Mogi Guaçu. A determinação de aminoácidos foi realizada em analisador automático Beckman 119-CL, e os perfis de aminoácidos das quatro espécies foram semelhantes, sendo o ácido glutâmico o principal, os níveis variaram entre 19 a 22g/16g N; seguido do ácido aspártico, com níveis entre 11 a 
14g/16g N; lisina, 10 a 13g/16g N; leucina, 9 a 12g/16g N; arginina, 7 a 9g/16g N e alanina, 7 a $8 \mathrm{~g} / 16 \mathrm{~g}$ N. Todavia, os escore químico (EQ) para o cálculo da qualidade das proteínas dos peixes investigados, para a maioria dos aminoácidos essenciais presentes nas proteínas totais, foram superiores aos padrões estabelecidos, com exceção para os aminoácidos sulfurados (metionina + cisteína) que foram limitantes em tilápia e curimbatá.

\subsection{2 Ácidos graxos}

Os lipídeos de pescado contêm grande quantidade de ácidos graxos altamente insaturados, sendo suscetíveis de serem oxidados pela presença do oxigênio, bem como o período de coleta dos peixes, pode exercer efeito significativo sobre a composição de alguns ácidos graxos, como olêico e $\alpha$-linolênico (Beirão et al., 2000; Netto de Oliveira et al., 2000).

A oxidação é uma das principais causas de deterioração da qualidade de produtos cárneos. A suceptibilidade do tecido muscular à oxidação deve-se a sua alta concentração de catalisadores (ferro e mioglobina) e a lipídeos. Lipídeos oxidados reagem com outros componentes do alimento como proteínas, carboidratos e vitaminas (Cândido et al., 1998; Hultin, 1994).

Os resultados referentes a análise de ácidos graxos encontram-se na Tabela 9 para o pescado não irradiado e irradiado armazenado sob refrigeração, por até 20 dias. 
Tabela 9- Percentuais de ácidos graxos do pescado não irradiado e irradiado armazenado sob refrigeração por até 20 dias. Média de resultados em triplicata.

\begin{tabular}{|c|c|c|c|c|c|c|c|c|}
\hline \multirow[b]{2}{*}{ Ácidos Graxos } & \multicolumn{8}{|c|}{ Doses (kGy) / Tempo de Armazenamento } \\
\hline & NI & NI & $1 \mathrm{kGy}$ & $1 \mathrm{kGy}$ & 2,2kGy & 2,2kGy & 5 kGy & $5 \mathrm{kGy}$ \\
\hline C12:0 & -- & -- & -- & 0,2 & -- & -- & 2,4 & -- \\
\hline $\mathrm{C} 14: 0$ & 3,3 & 5,6 & 3,5 & 5,8 & 3,3 & 3,1 & 4,7 & 4,7 \\
\hline C15:0 & 0,4 & 0,6 & 0,5 & 0,7 & 0,4 & 0,4 & 0,7 & 0,6 \\
\hline $\mathrm{C} 16: 0$ & 22,8 & 33,5 & 22,7 & 37,1 & 22,0 & 27,2 & 25,7 & 27,3 \\
\hline C18:0 & 5,1 & 7,6 & 5,3 & 7,9 & 5,3 & 7,6 & 5,0 & 4,9 \\
\hline C20:0 & 0,2 & 0,2 & 0,5 & 0,3 & 0,6 & 0,5 & 0,2 & 0,2 \\
\hline $\mathrm{C} 22: 0$ & 0.7 & -- & 1,1 & -- & 1,4 & 0,5 & 0,5 & 0,5 \\
\hline Saturados & 32,5 & 47,5 & 33,6 & 52,0 & 33,0 & 39,3 & 39,2 & 38,2 \\
\hline $\mathrm{C} 16: 1 \omega 7$ & 6,1 & 6,7 & 6,4 & 6,7 & 6,2 & 5,5 & 7,5 & 8,3 \\
\hline 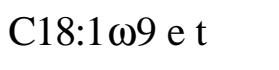 & 38,1 & 37,3 & 36,2 & 33,7 & 36,5 & 38,8 & 32,4 & 33,8 \\
\hline $\mathrm{C} 20: 1 \omega 11$ & 0,6 & -- & -- & -- & -- & 0,3 & -- & -- \\
\hline Monoinsaturado & 44,8 & 44,0 & 42,6 & 40,4 & 42,7 & 44,6 & 39,9 & 42,1 \\
\hline $\mathrm{C} 18: 2 \omega 6$ e $\mathrm{t}$ & 16,6 & 2,7 & 16,1 & 2,1 & 16,4 & 9,1 & 13,7 & 11,5 \\
\hline $\mathrm{C} 18: 3 \omega(\alpha$ e $\gamma)$ & 2,8 & 1,8 & 3,1 & 1,3 & 3,0 & 2,9 & 3,2 & 2,8 \\
\hline $\mathrm{C} 20: 2 \omega 6$ & 0,8 & 2,8 & 0,9 & 3,8 & 0,8 & 1,4 & 0,5 & 0,5 \\
\hline 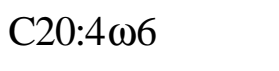 & 0,5 & -- & 0,8 & -- & 0,7 & 0,4 & 0,9 & 0,9 \\
\hline $\mathrm{C} 20: 5 \omega 3$ & -- & -- & 0,5 & -- & -- & 0,2 & 0,1 & 0,3 \\
\hline $\mathrm{C} 22: 5 \omega 6$ & 0,3 & -- & 0,4 & -- & 0,5 & 0,3 & 0,6 & 0,6 \\
\hline $\mathrm{C} 22: 5 \omega 3$ & -- & -- & -- & -- & 0,5 & -- & 0,4 & 0,3 \\
\hline $\mathrm{C} 22: 6 \omega 3$ & 0,4 & -- & 0,9 & -- & 1,0 & 0,4 & 0,9 & 0,6 \\
\hline Polinsaturados & 21,4 & 7,3 & 22,7 & 7,2 & 22,9 & 14,7 & 20,3 & 17,5 \\
\hline Não identificado & 1,3 & 1,2 & 1,1 & 0,4 & 1,4 & 1,4 & 0,6 & 2,2 \\
\hline
\end{tabular}

O efeito das radiações nas gorduras é similar ao da autoxidação, com hidroperóxidos inicialmente produzidos durante a irradiação. Isto pode ser consideravelmente diminuído, se o 
alimento é irradiado a baixas temperaturas sem a presença de oxigênio ou luz (Kraybill, 1983; Ogawa \& Maia, 1999).

Ogawa \& Maia (1999) analisaram três espécies de pescado de água doce, quanto ao

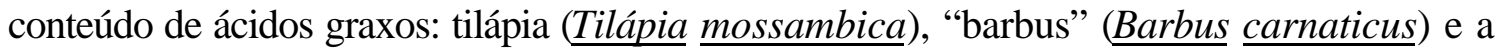
cobra-do-mar ( $\underline{\text { Ophichthidae }})$, sendo que a extração dos lipídeos foi realizada com clorofórmio-metanol, seguida de concentração, saponificação, esterificação e análise por cromatografia gasosa. Foram analisados 26 ácidos graxos, sendo encontrados teores de 33,7 a 49,3\% de saturados; 29,9 a $37,5 \%$ de monoinsaturados e 18,1 a $33,2 \%$ de polinsaturados para as três espécies.

Moreira et al. (2000) analisaram o perfil de ácidos graxos de pirapitanga ( $\underline{B}$. $\underline{\text { hilarii }})$ e matrinchã (Brycon $\underline{\text { cephalus })}$, pela metodologia de Bligh \& Dyer (1959) obtendo como resultados, C16:0 com 22,2 e 26,7\%; C18:0 com 9,00 e 10,0\%; C18:1 19 com 45,8 e

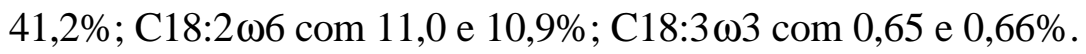

Visentainer et al. (2000) caracterizaram o perfil de ácidos graxos em tilápias do Nilo jovens ( $\underline{\text { Oreochromis }} \underline{\text { niloticus }}$ ), sendo lipídeos totais extraídos por Bligh \& Dyer (1959) e a metilação e quantificação dos ácidos graxos, pela metodologia de Joseph \& Ackman (1992). Obtiveram um total de 46 ácidos graxos, caracterizados com 25,66\% correspondente ao C18:1n9; 19,32\% ao C16:1 e 19,79\% por C18:2n6, dentre os mais abundantes. A somatória dos ácidos graxos saturados foi de 28,65\%; monoinsaturados com 34,93\%; polinsaturados com $15,90 \%$ e outros $1,53 \%$. Notou-se, ainda que, o teor de lipídeos totais em tilápias jovens foram superiores quando comparados com tilápias adultas. 
Os percentuais encontrados de ácidos graxos, nesta pesquisa, para o pescado irradiado com doses de 1; 2,2 e 5 kGy, quando comparados a valores já descritos para tilápia fresca, de acordo com Ackman (1994) e Maia \& Rodriguez-Amaya (1993), mantiveram-se estáveis após o período de armazenamento, principalmente, para a amostra irradiada a $5 \mathrm{kGy}$, que apresentou-se estável durante os períodos analisados.

\subsubsection{Vitamina B1 (tiamina) e vitamina A}

A grande importância do pescado como alimento não resulta apenas no seu teor protéico, mas também nas vitaminas que apresenta. São especialmente ricos em vitaminas A e D, o fígado dos peixes magros e o óleo obtido deles. Enquanto a vitamina B1 encontra-se em maiores quantidades nos músculos escuros, fígado e nos olhos. A tiamina é degradada pela enzima tiaminase, presente mais nas vísceras do que na carne da maioria dos peixes, mariscos e crustáceos. Entretanto, esta enzima é inativada pelo aquecimento (Ogawa \& Maia, 1999; Silva, 1993).

Analisou-se o teor de tiamina (vitamina B1) e vitamina A em filés de pescado não irradiados e irradiados, no período inicial e após um período de 20 dias de armazenamento refrigerado, conforme Tabela 10. Observou-se que, através da metodologia utilizada, não houve quantificação que permitisse a discussão dos resultados destas vitaminas. Foi utilizada a metodologia de Manz \& Philipp (1988-modificado) para a determinação de vitamina A e Cunniff (1998-modificado) e Van de Weerdhof et al. (1973-modificado) para a determinação de vitamina B1. 
Tabela 10- Valores de vitamina B1 (em mg/100g), Retinol (em mcg/100g) e vitamina A (em UI/100g) no pescado não irradiado e irradiado armazenado sob refrigeração por até 20 dias.

\begin{tabular}{lcccccccc}
\hline & \multicolumn{7}{c}{ Doses (kGy)/ Tempo de Armazenamento } \\
Vitaminas & NI & NI & $1 \mathrm{kGy}$ & $1 \mathrm{kGy}$ & $2,2 \mathrm{kGy}$ & $2,2 \mathrm{kGy}$ & $5 \mathrm{kGy}$ & $5 \mathrm{kGy}$ \\
\hline Tiamina & 0,08 & 0,10 & 0,09 & 0,12 & 0,09 & 0,06 & 0,06 & 0,07 \\
Retinol & ND* & ND* & ND* & ND* & ND* & ND* & ND* & ND* \\
Vitamina A & ND* & ND* & ND* & ND* & ND* & ND* & ND* & ND* \\
\hline
\end{tabular}

* ND, significa não detectado, sendo que os resultados foram menores que $45 \mathrm{mcg} / 100 \mathrm{~g}$ para retinol e menores que $150 \mathrm{UI} / 100 \mathrm{~g}$ para vitamina A.

Segundo Stansby (1951) os lípides do fígado de pescado são os mais ricos em vitamina $\mathrm{A}$, enquanto os lípides distribuídos pelo corpo normalmente são pobres nessa vitamina.

As vitaminas hidrossolúvies são menos instáveis à irradiação que as lipossolúveis. A vitamina B1 (tiamina) em alimentos irradiados a $6 \mathrm{kGy}$ sofreu uma perda da ordem de $47 \%$ após a irradiação, de $10 \%$ com o cozimento e $54 \%$ com a combinação do cozimento com a irradiação. Todavia, a riboflavina e o ácido nicotínico são mais resistentes à irradiação (Fellows, 1988; Fox et al., 1992; Venugopal et al., 1999).

Em tilápia (Oreochromis spp.) e cavalinha-espanhola (Scomberomorous guttatus), as perdas de tiamina foram significantes quando utilizadas doses de 4,5 kGy. Efeito similar com irradiação de tilápia com dose de 1,0 kGy, enquanto o mesmo processo não apresentou 
perda de vitamina em carpa prateada. Segundo Venugopal et al. (1999) perdas de vitaminas são geralmente altas, quando do uso de processamentos térmicos em alimentos, comparados à baixas doses de irradiação.

Diehl (1992) conclui que, para se ter menor perda de vitamina A e B1, quando o alimento é tratado com irradiação, este deve ser embalado a vácuo e processado a baixa temperatura. Filés de $\underline{\text { Scyliorhinus }} \underline{\text { retifer }}$ irradiados a $0^{\circ} \mathrm{C}$, com dose de $3 \mathrm{kGy}$, não sofreram efeito no teor de vitamina A; enquanto, houve perda de $45 \%$ quando o mesmo foi irradiado a 30 kGy.

\subsection{Análise sensorial}

O teste de Hartley indicou a existência da homogeneidade entre os ensaios, ou seja, os quadrados médios residuais não diferiram entre si, o que possibilitou a análise conjunta dos dados. Portanto pode-se considerar para a análise dos dados, o delineamento experimental inteiramente ao acaso com os tratamentos dispostos no esquema fatorial 4 x 3 , referentes a 4 níveis de dose de radiação (0,0, 1,0, 2,2 e 5,0 kGy) e 3 períodos de armazenamento (1, 20 e 30 dias).

Uma atenção especial foi dada neste experimento, à aparência geral dos peixes armazenados, quanto à cor, odor e textura, os quais encontraram-se aceitáveis durante os primeiros 10 dias, sob armazenamento refrigerado. Após este período, alterações na cor e odor mostraram-se presentes, variando de um odor "ácido" a "rejeitável". A textura mostrouse mais íntegra no pescado irradiado em até 20 dias sob refrigeração; quanto ao pescado não 
irradiado, este apresentou alterações marcantes na textura, que variaram desde uma desintegração fácil das fibras, até grande presença de muco.

Os dados do teste hedônico foram submetidos à análise de variância e teste de Tukey e os resultados constam na Tabela 11 .

Tabela 11- Médias de doses para o teste hedônico de aparência e aroma do pescado não irradiado e irradiado armazenado sob refrigeração.

\begin{tabular}{lccc}
\hline & \multicolumn{3}{c}{ Tempo de Armazenamento } \\
Dose (kGy) & 1 & 20 & 30 \\
\hline NI & $3.97 \mathrm{~b}$ & - & - \\
1 & $6.51 \mathrm{a}$ & $6.57 \mathrm{a}$ & - \\
2.2 & $6.23 \mathrm{a}$ & $5.48 \mathrm{ab}$ & $4.94 \mathrm{a}$ \\
5.0 & $5.46 \mathrm{a}$ & $4.26 \mathrm{~b}$ & $3.88 \mathrm{a}$ \\
Valor F & $4.36 *$ & $5.70 *$ & $6.99 *$ \\
C.V. & $37.66 \%$ & $43.92 \%$ & $59.90 \%$ \\
DMS $(5 \%)$ & 1.30 & 1.36 & 1.26 \\
\hline
\end{tabular}

Pode-se observar que no primeiro dia de análise, as amostras de filés irradiadas tiveram boa aceitabilidade comparando-se com o peixe não irradiado, o qual, obteve a nota de 3,97 situando-se na escala entre os intervalos "desgostei regularmente" e "desgostei ligeiramente". Dentre os atributos observados pelos provadores, para a amostra não irradiada, constam: "aparência descolorida"; "descongelado há muito tempo"; "sem brilho"; "limbosa"; “amarela"; "esverdeada" e "pouco atrativa", indicando que o peixe já estava em processo de decomposição. Tais atributos foram reforçados pela avaliação do aroma, onde se obteve os 
parâmetros: "odor forte de peixe"; "desagradável"; "estragado" e "estranho", características observadas com os resultados das análises físico-químicas e microbiológicas, onde notou-se alterações de $\mathrm{pH}, \mathrm{BNVT}$, contagens elevadas de microrganismos psicrotrófilos e coliformes (Tabelas 5, 6 e 7).

Ainda no primeiro dia, entre as amostras de filés irradiadas, destacam-se as doses de 1 e 2,2 kGy, as quais obtiveram notas de 6,51 e 6,23, situando-se na escala nos intervalos de "gostei ligeiramente" e "gostei regularmente", ou seja próprias para a comercialização. A parcela irradiada com 5 kGy, obteve menor nota, 5,46 situando-se no intervalo entre "indiferente" e "gostei ligeiramente"; entretando, não diferindo estatisticamente das amostras irradiadas com as demais doses.

Os atributos de aparência observados pelos provadores, como: "brilhante"; “agradável”; "fresco"; "saudável”; "natural”; "clara"; "atrativa" e "rósea" indicaram as características originais do pescado fresco, bem como com boa qualidade sanitária. Os atributos de odor, como: "fresco"; "não muito forte de peixe" e "agradável", puderam servir também, como parâmetros para a qualidade observada pelos atributos de aparência.

Correlacionando-se com os resultados obtidos nas análises físico-químicas, observase também, estabilidade dos valores de pH, BVT, composição centesimal, TBARS, análises nutricionais e microbiológicas.

Aos vinte dias de armazenamento refrigerado, as amostras de filés irradiadas com 1 kGy mantiveram as mesmas características observadas no primerio dia de análise, não diferindo estatisticamente das amostras irradiadas com 2,2 kGy, cujas notas foram 6,57 e 
5,48, respectivamente. Os atributos observados pelos provadores, apresentaram características semelhantes às descritas no primeiro dia, ou seja: "rosado"; "firme"; "com brilho"; "bom aspecto"; "saudável"; "claro"; "úmido"; "fresco" e "limpo". Os resultados obtidos das análises físico-químicas e microbiológicas condizem com tais características. Já as amostras de filés irradiadas com $5 \mathrm{kGy}$, apresentaram nota mais baixa, 4,26 no intervalo de “desgostei regularmente" e "desgostei ligeiramente", diferindo estatisticamente das amostras de filés irradiadas com $1 \mathrm{kGy}$. Entretanto, os atributos de aparência observados pelos provadores indicam mais um efeito de embalagem do que da própria dose de irradiação, associada ao tempo de armazenamento, uma vez que os filés foram embalados com filme plástico de PVC e posterior irradiação. As características observadas como: "opaca"; "escura"; "ressecado"; "velho"; "sem brilho"; e "desidratado", demonstraram que o fato dos filés não estarem embalados em ausência de oxigênio, foi decisivo na sua rejeição sensorial.

Aos trinta dias de armazenamento, apenas as amostras de filés irradiadas com 2,2 e 5 kGy foram avaliadas sensorialmente entretanto, apresentaram notas entre 4,94 e 3,88 respectivamente, ou seja, abaixo do índice de aceitabilidade para o mercado. Os atributos observados foram: "esverdeado"; "pálido"; "sem brilho"; "beiradas secas"; "murcho"; "não fresco"; “cor estranha"; "escuro"; “opaco"; "velho" e "desagradável”. Todavia, os resultados obtidos com as análises físico-químicas, nutricionais e microbiológicas não condizem com tal parâmetro, confirmando novamente, o papel da embalagem interferindo na qualidade sensorial do produto. 
Os resultados das amostras de filés não irradiados não foram apresentados na Tabela 11 aos 20 e 30 dias de armazenamento, pois desde o primeiro dia de análise já apresentaram um nível de decomposição elevado, com características impróprias para o consumo.

A amostra de filés irradiados a $1 \mathrm{kGy}$ aos 30 dias de armazenamento refrigerado apresentou visivelmente, colônias de microrganismos e fungos, além do odor desagradável, sendo descartada. Os resultados foram confirmados pela análise microbiológica, a qual apontou elevado índice de contaminação (Tabelas 5, 6 e 7).

Segundo Disney (1969), em termos de qualidade e inspeção, a flacidez da carne é a mais útil indicação das condições de alterações presentes no pescado.

A irradiação pode ocasionar mudanças na textura, cor, odor e sabor dos alimentos tratados; normalmente, estas mudanças na qualidade sensorial dos alimentos tratados aumentam de intensidade, à medida que se aumenta a dose de irradiação. Por isso, quando a qualidade sensorial do alimento é uma etapa primordial no alimento, deve-se utilizar um tratamento com doses mais amenas, porém eficientes microbiologicamente (FAO/IOEA/OMS, 1966).

As embalagens plásticas nos produtos que são submetidos à redução ou eliminação de suas correspondentes cargas microbianas atuam como uma barreira, proporcionando um aumento da durabilidade dos gêneros alimentícios. Todavia, nem todos os polímeros são resistentes, com a mesma intensidade, à radiação gama. Experiências com materiais disponíveis no mercado brasileiro revelam diferentes níveis de tolerância, uma vez que alguns plásticos devem ser estabilizados para posterior irradiação, pois os efeitos causados pela 
radiação, mesmo em pequenas doses, afetam profundamente o material, alterando suas propriedades (Artel, 2000; Moraes, 2000).

Segundo Artel (2000) quando o PVC (policloreto de vinila) é irradiado, ocorre basicamente a quebra da ligação $\mathrm{C}-\mathrm{Cl}$, com subseqüente formação de $\mathrm{HCl}$ e duplas ligações conjugadas. É comum a formação de polienos na irradiação do PVC, que são importantes centros cromóforos; o PVC irradiado fica portanto, amarelado.

Além do efeito barreira contra o oxigênio e vapor de água, vem se tornando cada vez mais importante também a capacidade de retenção de nitrogênio, no caso de alimentos empacotados sob atmosfera controlada. Atualmente, os filmes de PVC utilizados para embalar carnes frescas, estão sendo substituídos por filmes com múltiplas camadas à base de copolímeros de estireno (SBS, Styroflex ${ }^{\circledR}$ ) e os critérios essenciais para a substituição dos filmes de PVC são as menores propriedades absolutas de barreira e o maior controle da permeabilidade do oxigênio (Rösch \& Wünsch, 2000). 


\section{CONCLUSÕES}

As amostras irradiadas, em especial para a irradiada a $5 \mathrm{kGy}$, mantiveram segurança microbiológica mesmo após 30 dias de armazenamento, apresentando índices microbiológicos abaixo dos estabelecidos pela legislação.

Após a análise do pescado irradiado comparado ao não irradiado, conclui-se que, sob o ponto de vista físico-químico, houve uma significativa estabilidade dos compostos estudados nas amostras irradiadas, principalmente com a dose de 5,0 kGy.

Houve interação entre a determinação de BNVT, NNP e a presença de microrganismos uma vez que, com o aumento do período de armazenamento, as amostras não irradiadas, apresentaram valores crescentes em BNVT e NNP, paralelamente à presença de microrganismos, cujas contagens foram crescentes, conforme o período de armazenamento.

Quanto ao $\mathrm{pH}$, para as amostras não irradiadas, foram encontrados valores entre 6,56 e 7,72, no início e após 20 dias de armazenamento, respectivamente. Enquanto, o menor valor de $\mathrm{pH}, 6,65$ foi observado na amostra irradiada com a dose de 5 kGy, após 30 dias sob refrigeração, valor em acordo com a legislação para pescado fresco. 
A radiação gama a $5 \mathrm{kGy}$, é uma alternativa para prolongar o tempo de vida útil das tilápias por até, pelo menos 30 dias, quando comercializadas na forma de minimamente processadas, mantidas sob refrigeração.

Quanto aos aspectos sensoriais, todas as amostras irradiadas mostraram-se favoráveis segundo os aspectos de aparência e aroma, por até 20 dias sob refrigeração. Todavia, a embalagem utilizada poderia ser considerada um fator desencadeador de reações oxidativas, uma vez que suas propriedades de barreira alteraram-se frente às radiações ionizantes.

Não houve perdas significativas com as doses utilizadas nesta pesquisa para aminoácidos e ácidos graxos, ou seja, a irradiação propiciou o aumento da vida útil de produtos frescos sem alteração nestes componentes. 


\section{REFERÊNCIAS BIBLIOGRÁFICAS}

ACKMAN, R.G. Seafood lipids. In: SHAHIDI, F.; BOTTA, J.R. Seafoods: chemistry, processing, technology and quality. New York: Blackie Academic \& Professional, 1994. cap.4, p.48-74.

AHMED, I.O, ALUR, M.D.; KAMAT, A.S et al. Influence of processing on the extension of shelf-life of Nagli-fish (Sillago sihama) by gamma radiation. International Journal of Food Science and Technology, v.32, n.4, p.325-332, 1997.

ALLEN, E.; FOEGEDING, E.A. Some lipid characteristic and interactions with muscle foods: a reviw. Food Technology, v.35, n.5, p.253-257, 1981.

AL-KAHTANI, H.A; ABU-TARBOUSH, H.M; BAJABER, A. S. et al. Chemical changes after irradiation and post-irradiation storage in tilapia and spanish mackerel. Journal of Food Science, v.61, n.4, p.729-733, 1996. 
AMLACHER, E. Rigor mortis in fish. In: BORGSTROM, G. Fish as food. New York: Academic Press, 1961. v.3, p.329-359.

ANDRADE, M.O. Preparo, seleção, armazenamento e estudos químicos e sensoriais de conservas de mandi, Pimelodus clarias, Bloch. São Paulo, 1975. 127p. Dissertação (Mestrado) - Faculdade de Ciências Farmacêuticas, Universidade de São Paulo.

ANÁLISE de perigos e pontos críticos de controle na qualidade e segurança microbiológica de Alimentos. São Paulo: Varela, 1988.

ARAÚJO, M.G.; GASPAR, A.; MONTENEGRO, M. Tempo de prateleira de pescadinha (Cynoscion spp.) resfriada. Avaliação quanto aos aspectos físicoquímicos e sensoriais. In: CONGRESSO BRASILEIRO DE CIÊNCIA E TECNOLOGIA DE ALIMENTOS, 17., Fortaleza, 2000. Resumos. Fortaleza: Sociedade Brasileira de Ciência e Tecnologia de Alimentos, 2000. v.1, p.3-187.

ARTEL, B.W.H. Efeitos da radiação em polímeros. Plástico moderno, p.37-38, 2000.

AMERICAN OFFICIAL METHODS OF ANALYSIS OF AOAC INTERNATIONAL. Official methods of analysis. 16.ed. Arlington: AOAC, 1995. 2v.

BARD, J. Piscicultura intensiva de tilápias. Informe Agropecuário, v.67, n.6, p.24-29. 1980. 
BEIRÃO, L.H.; TEIXEIRA, E.; MEINERT, E.M. et al. Processamento e industrialização de moluscos. In: SEMINARIO E WORKHOP “TECNOLOGIA PARA APROVEITAMENTO INTEGRAL DO PESCADO”. Campinas, 2000. Resumos. Campinas: ITAL, 2000. p.38-84.

BLISKA, F.M.M. Importância do desenvolvimento tecnológico para sobrevivência da agroindústria. Campinas: CTC/ITAL, 1997. p.46-47. (Tecnocarnes, 7)

BLIGH, E.G. Specific problems in the quality assessment of freshwater fish. Fish inspection and quality control. London: Fishing News, 1971. p.81-86.

BOBBIO, P.A. Química do processamento de alimentos. 2.ed. São Paulo: Varela, 1992. 151p.

BOMBO, R. de P.A. Avaliação do efeito das radiações ionizantes sobre os ácidos graxos e antioxidantes de feijões (Phaseolus vulgaris, L.). São Paulo, 1998. 99p. Dissertação (Mestrado) - Faculdade de Ciências Farmacêuticas, Universidade de São Paulo.

BOMBO, R.de P.A; OETTERER, M.; MANCINI FILHO, J. Efeito das radiações ionizantes sobre os nutrientes. Piracicaba: ESALQ, Depto. de Ciência e Tecnologia Agroindustrial, 1996. 26p. 
BRASIL. Leis, decretos, etc. Portaria n. ${ }^{\circ} 451$ de 19 de setembro de 1997. Diário Oficial, 22 de set. de 1997. Seção 1, Ministério da Saúde, p. 21005-21012. Aprova o regulamento técnico, princípios gerais para o estabelecimento de critérios e padrões microbiológicos para alimentos e seus anexos I,II e III.

BRASIL. Leis, decretos, etc. Lei n. ${ }^{\circ}$ 1283, de 18 de dez. de 1950. Seção 1, p.74. Pescados e derivados, 1976.

BRASIL. Ministério da Saúde. In: ASSOCIAÇÃO BRASILEIRA DAS INDÚSTRIAS DE ALIMENTOS. Compêndio de legislação de alimentos: consolidação das normas e padrões para alimentos. São Paulo: ABIA, 1996. v.1/A.

BRASIL. Ministério da Agricultura. Decreto n. ${ }^{\circ}$ 30.691, de 29 de mar. de 1952. Regulamento da inspeção industrial e sanitária de produtos de origem animal. (RIISPOA). 1952.

BRUHN, C.M.; WOOD, D.B. Position of the American Dietetic Association: food irradiation. Journal of the American Dietetic Association, v.96, n.1, p.69-71, 1996.

CÂNDIDO, L.M.B.; NOGUEIRA, A.K.; SGARBIERI, V. Propriedades funcionais de concentrados protéicos de pescado preparados por vários métodos. Brazilian Journal of Food Tecnology, v.1, n.1/2. p.77-89, 1998. 
CAStagnOLli, N. Criação de peixes de água doce. Jaboticabal: FUNEP, 1992. $189 \mathrm{p}$.

CAÚLA, F.C.B.; OGAWA, N.B.P.; MAIA, E.L. Determinação do teor de colesterol em pescado de água marinha e doce. In: CONGRESSO BRASILEIRO DE CIÊNCIA E TECNOLOGIA DE ALIMENTOS, 17., Fortaleza, 2000. Resumos. Fortaleza: Sociedade Brasileira de Ciência e Tecnologia de Alimentos, 2000. v.2. p.5-233.

CHURCH, N. Modified-atmosphere packaging fish and crustaceans-sensory enhancement. Food Science and Technology Today, v.2, n.12, p.73-83, 1998.

COBB III, B.F.; VANDERZANT, C.; HYDER, K. Effect of ice storage upon free aminoacids content of tails of white shrimp. Journal Agriculture and Food Chemistry, v.22, n.6, p.1052-1055. 1974.

CONNELL, J.J. Controle de la calidad del pescado. Zaragoza: Acribia, 1988. cap.4, p.80-135: Alteracion y defectos extrinsecos de la calidad en el material fresco.

CONTRERAS-GUZMÁN, E.S. Bioquímica de pescados e derivados. Jaboticabal: FUNEP, 1994. 409p.

COURTHIADE. P. La importancia de la evaluación sensorial en la selección de un sabor. La Alimentación Latinoamericana, v.33, n.229, p.40-41. 1999. 
CUNNIFF,P. In: Association of Official Analytical Chemists. Official methods : 942.23, thiamine (vitamin B1) in human and pet foods. 16.ed., cap.45, p.6-7, 1998. (modificado).

DAMS, R.I.; BEIRÃO, L.H.; TEIXEIRA, E. Implantação de um sistema de análise de risco e pontos críticos de controle na indústria de pescado. Revista Nacional da Carne, v.18, n.204, p.63- 64, 1994.

DASSO, I. Qué ponemos en juego al degustar un alimento? La Alimentación Latinoamericana, v.33, n.229, p.34-36, 1999.

DEAN, L.M. Nutrition and preparation. In: MARTIN, R.E.; FLICK, G.J. The seafood industry. New York: Van Nostrand Reinhold, 1990. cap.16, p.255-267.

DERR, D.D.; ENGELJOHN, D.L.; GRIFFIN, R.L. Progress of food irradiation in the United States. Radiation Physics Chemistry, v.46, n.4/6, p.681-688, 1995.

DIEHL, J.F. Safety of irradiated foods. 2.ed. New York: Marcel Dekker, 1992. 454p.

DELINCÉE, H. Detection methods for irradiated foods: na overview. Radiation Physics Chemistry, v.48, n.3, p.378-379, 1996. 
DISNEY, J.G. Quality assessment in tilapia species. /Presented to Technical Conference on Fish Inspection and Quality Control, Halifax, 1969. 10p/

DUTCOSKY, S.D. Análise sensorial de alimentos. Curitiba: Champagnat, 1996.123p.

EDDIE, G.C. Road transport of fish and fishery products. Roma: FAO, 1983. 54p.

EIROA, M.N.U. Aspectos microbiológicos relacionados à conservação e ao consumo de pescado. Boletim da Sociedade Brasileira de Ciência e Tecnologia de Alimentos, v.54, p.9-37, 1980.

EHLERMAM, D.; DELINCÉE, H. Lebnsmittelbestrahlung antworten auf oft gestellte fragen. BFE: s.ed., 1996. 8p.

FAO. Ice in fisheries. Roma, 1968. 68p. (FAO Fisch Report, n. 59)

FAO. Summary information on the role of international fishery and other bodies with regard to the conservation and management of living resources of the high seas. Roma, 1996. 104p.

FAO/ INTERNATIONAL ORGANIZATION OF ENERGY ATOMIC /ORGANIZATION MUNDIAL DE LA SAULUD. Bases tecnicas para la legislacion referente a los alimentos irradiados. Roma, 1966. 62p. 
FAULHABER, C. A importância de um sistema de inspeção e controle de qualidade dos produtos da pesca. In: KAI, M.; RUIVO, U.E. Coord.) SEMINÁRIO SOBRE CONTROLE DE QUALIDADE DE PESCADO. São Paulo, 1988. Resumos. São Paulo: Loyola, 1988. p.21-26.

FELLOWS, P. Food processing technology: principles and practice. Chichester: Horwood, 1988. p.186-195.

FENNEMA, O. Water and ice. In: FENNEMA, O.R. Food chemistry, New York: Marcel Dekker, 1985. cap. 2, p.13-39.

FERRARI, C.K.B. Oxidação lipídica em alimentos e sistemas biológicos: mecanismos gerais e implicações nutricionais e patológicas. Revista de Nutrição, v.11, n.1, p.3-14, 1998.

FERREIRA, S.O. Aplicação de tecnologia a espécies de pescado de água doce visando atender a agroindústria rural. Piracicaba, 1987. 122p. Dissertação (Mestrado) Escola Superior de Agricultura “Luiz de Queiroz”, Universidade de São Paulo.

FIGUEIREDO, R.M. Ocorrência de coliformes e estreptococos fecais em alimentos com baixo teor de umidade. Piracicaba, 1991. 77p. Dissertação (Mestrado) - Escola Superior de Agricultura “Luiz de Queiroz”, Universidade de São Paulo. 
FINNE, G. Minced fish flesh fron nontraditional gulf of Mexico finfish species yeld and composition. Journal of Food Science, v.45, n.5, p.1327-1340, 1980.

FIRESTONE, D. Official methods and recommended of the American Oil Chemists Society. 5ed. Champaign: AOCS, 1998. v.2. (método 1/62)

FOX Jr, .J.B.; THAYER, D.W.; JENKINS, R.K. et al. Effect of gamma irradiation on the B vitamins on pork chops nad chicken breasts. International Journal Radiation Biologie, n.55, p.689-703, 1989.

FOX Jr., J.B.; ACKERMAN, S.; THAYER, D.W. The effect of radiation scavengers on the destruction of thiamin and riboflavin in buffers and pork due to gamma irradiation. Prehrambeno-Technologie Biotechonologie Rewies, v.30, n.4, p.171$175,1992$.

FRANCO, B.D.G.M.; GUTH, B.E.C. Isolamento e caracterização de cepas de Escherichia coli isoladas de alimentos. Revista de Microbiologia, v.16, n.1, p.49$55,1985$.

FRAZIER, W.C. Contaminación, conservación y alteraciones del pescado y outros productos marinhos. Microbiologia de los alimentos. 2.ed. Zaragoza: Acribia, 1976. p.280-291. 
GEIGER, E. Fish protein-nutritive aspects. In: BORGSTRON, G. Fish as food. New York: Academic Press, 1962. v.2, p.32-38.

GELLI, D.S.; TACHIBANA, T.; SAKUMA, M. Ocorrência de Vibrio parahaemolyticus, Escherichia coli e de bactérias mesófilas em ostras. Revista do Instituto Adolfo Lutz, v.39, n.1, p.61-66, 1979.

GERMANO, P.M.L.; OLIVEIRA, J.C.F.; GERMANO, M.I.S. Aspectos da qualidade do pescado de relevância em saúde pública. Higiene Alimentar, v.12, n.53, p.30-37, 1998.

GHADI, S.V.; VENUGOPAL, V. Influence of gama irradiation and ice storage on fat oxidation in three Indian fish. Internacional Journal of Food Science and Technology, v.26, n.4, p.397-401, 1991.

GOEPFERT, J.M. The aerobic patle count, coliform and Escherichia coli content of raw ground beef at the retail level. Journal of Food Technology, v.39, n.3, p.175178, 1976.

GÓES, J.A.W. Efeito do atraso no resfriamento sobre a caracterização da qualidade da tilápia (Oreochromis niloticus) conservada com gelo. Lavras, 1987. 118p. Dissertação (M.S.) - Escola Superior de Agricultura de Lavras. 
GONÇALVES, P.M.R. Toxinfeções alimentares: uma revisão. Higiene Alimentar, v.12, n.53, p.38-44, 1998.

GRAM, L.; HUSS, H.H. Microbiological spoilage of fish productos. In: VENUGOPAL, V.; DOKE, S.N.; THOMAS, P. Radiation processing to improve the quality of fishery products. Critical Reviews in Food Science and Nutrition, v.39, n.5, p.391-440, 1999.

GRUIZ, K.; KISS, I. Effect of ionizing radiation en the lipids in frozen poultry. Acta Alimentaria, v.16, n.2, p.111-127, 1987.

GRUPO CONSULTIVO INTERNACIONAL SOBRE IRRADIAÇÃO DE ALIMENTOS-GCIIA. A irradiação de alimentos: ficção e realidade. s.n.t. 1990. 40p.

GURGEL, M.S. de C.C. do A. Efeito da radiação gama na resistência do Staphylococcus aureus (Rosembach, 1884) e nas propriedades físico-químicas e sensoriais do queijo Minas Frescal. Piracicaba, 2000. 81 p. Tese (Doutorado) Centro de Energia Nuclear na Agricultura, Universidade de São Paulo.

HOFFMANN, F.L.; GARCIA-CRUZ, C.H.; VINTURIM, T.M. et al. Levantamento da qualidade higiênico-sanitária de pescado comercializado na cidade de São José do Rio Preto (SP). Higiene Alimentar, v.13, n.64, p.45-48, 1999. 
HULTIN, H.O. Oxidation of lipids in seafoods. In: SHAHIDI, F.; BOTTA, J.R. Seafoods: chemistry, processing, technology and quality. New York: Blackie Academic \& Professional, 1994. p.48-74.

HUSSAIN, A. M., CHAUDRY, M.A.; HAQ, I. Effect of low doses of ionizing radiation on shelf-life of mackerel (Rastrelliger kanagurta). LebensmittelWissenschaft und Technologie, v.18, n.5, p.273-276, 1985.

HUSS, H.H.; DALSGAARDE, D.; HANSEN, L. et al. The influence of higiene in catch handling on the storage life of iced cod and plaice. Journal of Food Technology, v.4, n. 9, p.213-221, 1974.

HUTZIER, R.U. Utilização de irradiação em carne de aves e produtos derivados. Revista Nacional da Carne, n.250, p.34-37, 1997.

INTERNATIONAL ATOMIC ENERGY AGENCY. Radiation preservation of fishery products. Vienna, 1989. (Technologie Report Service, 303)

INTERNATIONAL COMISSION ON MICROBIOLOGICAL SPECIFICATIONS FOR FOODS. Microorganisms in foods: their significance and methods of enumeration. 2.ed. Toronto: University of Toronto Press, 1984. 434p. 
INTERNATIONAL CONSULTATIVE GROUP ON FOOD IRRADIATION. INTERNATIONAL ATOMIC ENERGY AGENCY. Irradiation as a quarantine treatment of frsh fruits and vegetables, 1991. (International Atomic Energy Agengy, n.13)

IRRADIAÇÃO de alimentos. Boletim Embrarad, v.3, n.6, p.1-4, 1983.

JAY, J.M. Modern food microbiology. New York: Van Nostrand Reinhold, 1970. $328 \mathrm{p}$.

KAI, M.; MORAIS, C. Vias de deterioração do pescado. Controle de qualidade. São Paulo: Loyola, 1988. p.13-20.

KÄFERSTEIN, F.; ABDUSSALAM, M. Food safety in the $21^{\text {st }}$ century. Bulletin of the World Health Organization, v.77, n.4, p.347-351, 1999.

KAMAT, S.V.; KUMTA, U.S. Studies on radiation preservation of medium fatty fish; control of radiation induced oxidative changes in white pomfret (Stromateus cinereus) by vacuum packaging. Fishery Technology, v.9, n.1, p.8-16, 1972.

KANNER, J. Oxidative processes in meat and meat products: quality implications. Meat Science, v.36, n.1/2, p.169-189, 1994. 
KHAYAT, A.; SCHWALL, D. Lipid oxidation in seafood. Food Technology, v.37, n.7, p.130-140, 1983.

KIETZMANN, U.; PRIEBE, K.; RAKOW, D. et al. Inspeccion veterinaria de pescados. Zaragoza: Acríbia, 1974. p.1-3.

KILCAST, D. Effect of irradiation on vitamins. Food Chemistry, v.49, p.157-164, 1994.

KONOSU, S.; YAMAGUCHI, K. The flavor components in fish and shellfish. In: FLICK, G.J., HEBARD, C.E., WARD, D.R. Chemistry \& biochemistry of marine food products. Connecticut: Avi Publ. 1982.

KRAYBILL, H.F. Effect of processing on nutritive value of food: irradiation. In: JOSEPHSON, E.S.; PETERSON, M.S. Preservation of food by ionizing radiation. Boca Ration: CRC Press, 1983. p.181-208.

LAHIRY, N.L.; MOORJANI, M.N.; BALIGA, B.R. Factores influencing the keeping quality of fresh o water fish in ice. Food Technology, v.9, n.17, p.123-125, 1963.

LEITÃO, M.F. de F. Microbiologia do pescado e controle sanitário no processamento. Boletim do Instituto de Tecnologia de Alimentos, n.50, p.1-35, 1977. 
LEITÃO, M.F. de F. Microbiologia e deterioração do pescado fresco e refrigerado de origem fluvial ou marinha. In: SIMPÓSIO SOBRE CONTROLE DE QUALIDADE MICROBIOLÓGICO, QUÍMICO, FÍSICO E ORGANOLÉPTICO DE PESCADO E DERIVADO, Campinas. Anais. Campinas: ITAL, 1994. p.11-26.

LEITE, Q.R.; SEBASTIÃO, K.L.; ROMANELLI, M.F. et al. Teste do "Comet Assay" como uma detecção preliminar de frutos do mar irradiados. In: CONGRESSO BRASILEIRO DE CIÊNCIA E TECNOLOGIA DE ALIMENTOS, 17., Fortaleza, 2000. Resumos. Fortaleza: Sociedade Brasileira de Ciência e Tecnologia de Alimentos, 2000. v.1. p.3-198.

LIMA, F.C.; OLIVEIRA, L.A.T. Enumeração e identificação de coliformes fecais e Escherichia coli em lulas frescas comercializadas no município de Niterói - RJ. Higiene Alimentar, v.6, n.23, p.23-27, 1992.

LIMA dos SANTOS, C.A.M. Quality changes in iced Amazonian freswater catfish (Brachyplatystoma vaillanti, Valenciennes). In: JOINT MEETING OF THE INTERNATIONAL INSTITUTE OF REFRIGERATION, Paris, 1981. p.1-10.

LOAHARANU, P. Food irradiation in developing countries a practical alternative. 1994, p.30-35. (International Atomic Energy Agency Bulletins 1) 
LOZANO, J.E. El arte de evaluar los sabores. La Alimentación Latinoamericana, v.33, n.229, p.42-43, 1999.

LUDORFF, W.; MEYER, V. El pescado y sus produtos de la pesca. 2ed. Zaragoza: Acríbia, 1978. p.32-55.

LUSK, J.L.; FOX, J.A.; MCILVAIN, C.L. Consumer acceptance of irradiated meat. Food Technology, v.53, n.3, p.56-59, 1999.

LUZIA,L.A.; SAMPAIO, G.R.; CASTELLUCCI, C.M.N. et al. Avaliação da peroxidação lipídica em cinco espécies populares de pescados. In: CONGRESSO BRASILEIRO DE CIÊNCIA E TECNOLOGIA DE ALIMENTOS, 17., Fortaleza, 2000. Resumos. Fortaleza: Sociedade Brasileira de Ciência e Tecnologia de Alimentos, 2000. v.2. p.5-133.

MACHADO, I. C. Alterações "post-mortem" no pescado. In: SIMPÓSIO SOBRE CONTROLE DE QUALIDADE MICROBIOLÓGICO, QUÍMICO, FÍSICO E ORGANOLÉPTICO DE PESCADO E DERIVADO, Campinas. Anais. Campinas: ITAL, 1994. p.1-10. 
MADRID, R.M. Avança Brasil: Programa de Desenvolvimento da Aqüicultura. In: SEMINÁRIO E WORKHOP “TECNOLOGIA PARA APROVEITAMENTO INTEGRAL DO PESCADO”, Campinas, 2000. Resumos. Campinas: ITAL, 2000. p.1-4.

MAIA, E.L. Caracterização dos constituintes lipídicos e composição em aminoácidos de peixes de água doce. Campinas, 1992. Tese (Doutorado) - Faculdade de Engenharia de Alimentos, Universidade Estadual de Campinas.

MAIA, E.L.; RODRIGUEZ-AMAYA, D.B. Avaliação de um método simples e econômico para a metilação de ácidos graxos com lipídios de diversas espécies de peixes. Revista do Instituto Adolfo Lutz, v.53, n.1/2, p.27-35, 1993.

MAIA, E.L.; OGAWA, M. Composição em aminoácidos de peixes de água doce. In: CONGRESSO BRASILEIRO DE CIÊNCIA E TECNOLOGIA DE ALIMENTOS, 17., Fortaleza, 2000. Resumos. Fortaleza: Sociedade Brasileira de Ciência e Tecnologia de Alimentos, 2000. v.2. p.5-37.

MANZ, U.; PHILIPP, K. Determination of vitamin A in complete feeds and premixes and vitamin concentrates with HPLC. In: Analytical methods for vitamins and carotenoids in food. Switzerland, 1988. (modificado) 
MARCHI, J.F. Desenvolvimento e avaliação de produtos à base de polpa e surimi produzidos a partir de tilápia nilótica (Oreochromis niloticus) L. Viçosa, 1997. 85p. Dissertação (M.S.) - Universidade Federal de Viçosa.

MAYER-MIEBACH, E. Food irradiation- a means of controlling pathogenic microorganisms in food. Lebensmittel Wissenschaft und Technologie, v.26, n.6, p.493-497, 1993.

MEDEIROS, F.; TOLEDO, L.; KLEIBER, L.. et al. Pescado: Brasil joga a rede. Exportar \& Gerência, n.21, p.18-25, 2000.

MERRITT Jr., C.; VAJDI, M.; ANGELINI, P. A quantitative comparison of the yields of radiolytic products in various meats and their relationship to precursors. Journal American Oil Chemistry Society, v.62, p.708-713, 1985.

MONTENEGRO, A. A costa do Brasil. Folha de São Paulo. Suplemento: Oceanos, São Paulo,1998. p.10.

MOORE, S.; STEIN, W. Chromatografic determination of aminoacids by the use of automatic recording equipments. Methods in Enzymology, v.6, p.919-931, 1963.

MORAES, R. de A tolerância dos polímeros à radiação. Plástico Moderno, p.34-36, 2000. 
MOREIRA, A.B.; VISENTAINER, N.E.; MATSUSHITA, M. Ácidos graxos em Brycon cephalus (matrinchã) e B. hilarii (pirapitanga) criados em cativeiro. In: CONGRESSO BRASILEIRO DE CIÊNCIA E TECNOLOGIA DE ALIMENTOS, 17., Fortaleza, 2000. Resumos. Fortaleza: Sociedade Brasileira de Ciência e Tecnologia de Alimentos, 2000. v.2, p.5-50.

MORGA, A.A. Avaliação do índice de frescor da pescada foguete (Macrodon ancylodon), conservada em gelo. Campinas, 1975. 80p. Dissertação (Mestrado) Faculdade de Engenharia de Alimentos e Agrícola, Universidade Estadual de Campinas.

MUJICA, P.Y.C. Avaliação da qualidade organoléptica, química e microbiológica da tilápia-do-nilo (Oreochromis niloticus) mantida à temperatura ambiente e sob gelo. Viçosa, 1988. 75p. Dissertação (M.S.) - Universidade Federal de Viçosa.

MUJICA, P.Y.C. Deterioração química e microbiológica do cação (Prionace glauca) e otimização de seu aproveitamento industrial. Campinas, 1999. 106p. Tese(Doutorado) - Faculdade de Engenharia de Alimentos, Universidade Estadual de Campinas.

NASH, C.E. A global overview of aquaculture production. Journal of the World Aquaculture Society, v.19, n.2, p.51-57, 1988. 
NAGEL, L. Aquaculture in the third world. Animal Research and Development, n.9, p.77-114, 1979.

NATARAJAN, V.M.; SREENIVASAN, A. Proximate and mineral composition of freshwater fishes. Indian Journal of Fisheries, v.2, n.8, p.422-429, 1961.

NAWAR,W.W. Radiolysis of nonaqueous components of foods. In: JOSEPHSON, E.S.; PETERSON, M.S. Preservation of food by ionizing radiation. New York: CRC Press, 1983. v.2, p.75-124.

NETTO DE OLIVEIRA, E.R.; MATSUSHITA, M.; AGOSTINHO, A.A. Ácidos graxos em filés de Hypophythalmus edentatus (mapará ou sardela) capturados no reservatório de Itaipu - PR. In: CONGRESSO BRASILEIRO DE CIÊNCIA E TECNOLOGIA DE ALIMENTOS, 17., Fortaleza, 2000. Resumos. Fortaleza: Sociedade Brasileira de Ciência e Tecnologia de Alimentos, 2000. v.2, p.5-23.

NICOLUZZI, R. Mercado internacional de pescado: as oportunidades brasileiras na Europa, América do Norte e Cone Sul. Higiene Alimentar, v.7, n.28, p.5-6, 1993.

OGAWA, M.; MAIA, E.L. Manual de pesca: ciência e tecnologia do pescado. São Paulo: Varela, 1999. v.1, 430p. 
OGAWA, M.; MAIA, E.L.; OGAWA, N.B.P. et al. Análise de aminoácidos livres em carne de caranguejo. In: CONGRESSO BRASILEIRO DE CIÊNCIA E TECNOLOGIA DE ALIMENTOS, 17., Fortaleza, 2000. Resumos. Fortaleza: Sociedade Brasileira de Ciência e Tecnologia de Alimentos, 2000. v.2, p.5-244.

OETTERER, M. Matéria-prima alimentar: pescado. São Caetano do Sul: Centro de Pesquisas do Instituto Mauá de Tecnologia, 1991. 29p.

OETTERER, M. Técnicas de beneficiamento e conservação do pescado de água doce. Panorama da Aqüicultura, v.8, n.46, p.14-20, 1998.

OETTERER, M. Agroindústrias beneficiadoras de pescado cultivado: unidades modulares e polivalentes para implantação, com enfoque nos pontos críticos higiênicos e nutricionais. Piracicaba. 1999. 196p. Tese (Livre - Docência). Escola Superior de Agricultura “Luiz de Queiroz”, Universidade de São Paulo.

ORGANIZATION MUNDIAL DE LA SALUD - OMS. Inocuidade de los Alimentos. Genebra, 1984. (Série de Informes Técnicos, 703)

PIGOTT, G.M.; TUCKER, B.W. Seafood: effects of technology on nutrition. New York: Marcel Dekker, 1990. cap.7, p.32-84, 176- 205. 
PIMENTEL-GOMES, F. Curso de estatística experimental. 13.ed. São Paulo: Nobel, 1990. 468p.

PINTO, M.C.C.B. O milagre no cativeiro. Panorama Rural, v.2, n.14, p.56-63, 2000.

POOLE, S.E.; MITCHELL, G.E.; MAYZE, J.L. Low irradiation affects microbiological and sensory quality of sub-tropical seafood. Journal of Food Science, v.59, n.1, p.85-87, 1994.

PRADO, L.G. Conservação do pescado. In: FONSECA, H.; PRADO, L.G.; ANDRADE, M.O; et al. Tecnologia dos produtos agropecuários: alimentos. São Paulo: Nobel, 1984. cap.10, p.165-189.

PREGNOLATO, W.; PREGNOLATTO, N.P. Normas analíticas do Instituto Adolfo Lutz. São Paulo: Instituto Adolfo Lutz, 1985. v.1, 533p.

PRESERVAÇÃO de alimentos via radiação gama. Boletim Embrarad, n.21, p.4, 1996.

RAY, B. Fundamental food microbiology. New York: CRC Press, 1996. 516p.

RELA, P.R. Cresce uso de irradiação para conservação de alimentos. Engenharia de Alimentos, v.6, n.29, p.26-29, 2000. 
RESURRECCION, A.V.A.; GALVEZ, F.C.F.; FLETCHER, S.M.; et al. Consumer attitudes toward irradiated food- results of a new study. Journal of Food Protection, v.58, n.2, p.193-196, 1995.

RESURRECCION, A.V.A.; GALVEZ, F.C.F. Will consumers buy irradiated beef? Food Technology, v.53, n.3, p.52-55, 1999.

ROITMAN, I.; TRAVASSOS, L.R.; AZEVEDO, J.L. Tratado de microbiologia. São Paulo: Manole, 1988. v.1, 186p.

RÖSCH, J.; WÜNSCH, J.R. Tendências em materiais com propriedades de barreira. Plástico Industrial, n.25, p.70-81, 2000.

RYDER, J.M.; FLETCHER, G.C.; STEC, M.G. et al. Sensory, microbiological and chemical changes in hoki stored in ice. Journal of Food Technology, v.18, n.2, p.169-180, 1983.

SALES, R.de O.; OLIVEIRA, J.A.P. de; COSTA, F.J.do L.; et al. Avaliação do estado de frescor do pescado capturado em água doce e mantido sob refrigeração, no açude de Orós, Ceará. Ciências Agronômicas, v.19, n.2, p.109-115, 1988. 
SALES, R. de O.; SALES, A. M. Estudo da composição química e rendimento de dez espécies de pescado de água doce de interesse comercial nos açudes do nordeste brasileiro. Ciências Agronômicas, v.1/2, n.21, p.27-30, 1990.

SANCHEZ, L. Pescado: matéria-prima e processamento. Campinas: Cargil, 1989. p.114.

SANT'ANA, L.S.; FERNANDES, J.B. Efeito do armazenamento na composição em ácidos graxos de filés de peixes da espécie pacu (Piaractus mesopotamicus). In: CONGRESSO BRASILEIRO DE CIÊNCIA E TECNOLOGIA DE ALIMENTOS, 17., Fortaleza, 2000. Resumos. Fortaleza: Sociedade Brasileira de Ciência e Tecnologia de Alimentos, 2000. v.4. p.5-272.

SAS Institute. SAS user's guide: statistic. 6ed. Cary: SAS Institute, 1988. 584p.

SATIN, M. Food irradiation: a guidebook. 2.ed. Lancarster: Technomic. 1996. 221p.

SAVAGON, K.A.; SREENIVASAN, A. Activation mechanism of pre-phenoloxidase in lobster and shrimp. Fishery Technologie, n.15, p.49-52, s.d.

SAVITCI, L.A.; GASPARINO FILHO, J.; MORETTI, V.A.; et al. Unidade comercial de irradiação: análise econômica. Coletânea do Instituto de Tecnologia de Alimentos, v.27, n.1, p.139-145, 1997. 
SEVANIAN, A., HOCHSTEIN, P. Mechanisms and consequences of lipid peroxidation in biological systems. Annual Review of Nutrition, v.5, p.365-390, 1985.

SHEWAN, J.M. The microbiology of sea-water fish. In: BORGSTROM, G. Fish as food. New York: Academic Press, 1961. v.3, p.487-560.

SIKORSKI, Z.N. Composición nutritiva de los principales grupos de organismos alimenticios marinos. Tecnologia de los productos del mar. Zaragoza: Acribia, 1990. p.41-72.

SIKORSKI, Z.E.; KOLAKOWSKA, A.; BURT, J.R. Postharvest biochemical and microbial changes. In: SIKORSKI, Z.E. Seafood: resources, nutritional, composition and preservation. Boca Raton: CRC Press, 1994. p.55-73.

SILVA, C.R. da. O pescado como alimento. Viçosa: Universidade Federal de Viçosa, 1993. p.1-15.

SILVA, N. da; JUNQUEIRA, V.C.A.; SILVEIRA, N.F. de A. Manual de métodos de análise microbiológica de alimentos. São Paulo: Varela, 1997. 295p.

SINGH, U.S.; SINGH, R.P.; KOHMOTO, K. Pathogenesis and host specificity in plant diseases: hitopathological, biochemical, genetic and molecular bases. New YorK: Oxford, 1995. 
SOARES, V.F.M.; VALE, S.R.; JUNQUEIRA, R.G.; et al. Teores de histamina e qualidade físico-química e sensorial de filé de peixe congelado. Ciência e Tecnologia de Alimentos, v.18, n.4, p.462-467, 1998.

SOUZA, F.G.de; OLIVEIRA, A.A.C.A.; ANDRADE, R.C.F. et al. Avaliação do desenvolvimento do nível de nitrogênio básico volátil em músculo de pacu (Piaractus mesopotamicus) em função do tempo pós-abate. In: CONGRESSO BRASILEIRO DE CIÊNCIA E TECNOLOGIA DE ALIMENTOS, 17., Fortaleza, 2000. Resumos. Fortaleza: Sociedade Brasileira de Ciência e Tecnologia de Alimentos, 2000. v.4, p.5-286.

STANSBY, M.E. Fish, shellfish and crustacea. In: JACOB, M.B. The chemistry and technology of food and food products. 2ed. New York: Interscience, 1951. v.2, p.943-944.

TAHA, P. Controle de qualidade do pescado exercido pela WEG PENHA PESCADOS S.A. In: KAI, M.; RUIVO, U.E. (coord.). SEMINÁRIO SOBRE CONTROLE DE QUALIDADE DE PESCADO, São Paulo, 1988. Resumos. São Paulo, 1998. p.210-215.

TARLADGIS, B.G.; WATTS, B.M.; YOUNATHAN, M.T.A. Destillation method for the quantitative determination of malonaldehyde in rancid foods. The Journal of the American Oil Chemist's Society, v.37, p.44-48, 1960. 
TOMIYASU, Y.; ZENITANI, B. Spoilage of fish and its preservation by chemical agents. Advances in Food Research, n.7, p.41-82, 1957.

TORNES, E.Y.; GEORGE, P. La conservación del pescado Industria conservera. Revista Técnica de la Industria de Conservas de Pescados, n.443, p.38-52, 1976.

TORRES, E.A.F.S., OKANI, E.T. Teste de TBA: ranço em alimentos. Revista Nacional da Carne, v.24, n.243, p.68-78, 1997.

TRUSWELL, A. S. Food irradiation II. http://www.food-irradiation.com/ srch.htm, June. 1987.

UNDERDAL, B.; NORDAL, J.; LUNDE, G. et al. The effect of ionizing on the nutritional value of Mackerel. Lebensmittel Wissenschaft und Technologie, v.9, n.2, p.72-74, 1976.

URBAIN, W.M. Biological effects of ionizing radiation. In: Food irradiation. Orlando: Academic Press, 1986, p.83-117.

URIOSTE, A.M.; CROCCI, C.A.; CURZIO, O.A. Consumer acceptance of irradiated onion in Argentina. Food Technology, v.44, n.5, p.134-136, 1990. 
VAN DE WEERDHOF, T; WIERSUN, M.L.; REISSENWEBER, H. Application of liquid chromatography in food analysis. Journal Chromatography, v.83, n.2-4, p.455-460, 1973 (modificado)

VANDERZANT, C.; SPLITTSTOESSER, D.F. Compendium of methods for the microbiological examination of foods. 3ed. Washington: American Public Health Association, 1992. 1219p.

VAZ, J. de O.; PARREIRA, W.B. A tilápia. São Paulo: Departamento de Produção Animal, s.d. 12p.

VENUGOPAL, V.; DOKE, S.N.; THOMAS, P. Radiation processing to improve the quality of fishery products. Critical Reviews in Food Science and Nutrition, v.39, n.5, p.391-440, 1999.

VIANA, C. M. Estudo bacteriológico de pescado refrigerado submetido à radiação gama. Niterói. 1993. 49p. Tese (Doutorado) - Universidade Federal Fluminense.

VILLAVICENCIO, J.L.C. Criterios administrativos para el manejo de la explotación agropecuaria. Caracas: Universidade Romulo Gallegos, 1992. 127p. 
VILLAVICENCIO, A.L.C.H. Avaliação dos efeitos da radiação ionizante de ${ }^{60}$ Co em propriedades físicas, químicas e nutricionais dos feijões Phaseolus vulgaris L. e Vigna unguiculata (L.) Walp. São Paulo, 1998. 138p. Tese (Doutorado) Faculdade de Ciências Farmacêuticas, Universidade de São Paulo.

VISENTAINER, J.V.; MATSUSHITA, M.; SOUZA, N.E. et al. Avaliação físicoquímica, composição de ácidos graxos e quantificação dos ácidos graxos LNA, EPA e DHA em filés de tilápias jovens. In: CONGRESSO BRASILEIRO DE CIÊNCIA E TECNOLOGIA DE ALIMENTOS, 17., Fortaleza, 2000. Resumos. Fortaleza: Sociedade Brasileira de Ciência e Tecnologia de Alimentos, 2000. v.2, p.5-222.

VITALI, A de A . Novas tendências em processamento de alimentos. Boletim da Sociedade Brasileira de Ciências e Tecnologia de Alimentos, v.31, n.1, p.15-16, 1997.

VOISINE, R.; HOMBOUGER, C.; WILEMOT, C.; et al. Effect of high carbon dioxide storage and gamma irradiation on membrane deterioration in cauliflower florets. Postharvest Biology Technologie, v.2, p.279-289, 1993.

WAGNER, S.C. Alimentos irradiados: una tendencia com grandes perspectivas. Industria Alimenticia, v.30, n.8, p.28-32, 2000. 
WORLD HEALTH ORGANIZATION. Safety and nutritional adequacy of irradiated food. Geneva, 1994.

YEH, C.S., NCKELSON II, R.; FINNE, G. Amonia producing enzymes in white shrimp tails. Journal of Food Science, v.43, n.5, p.1400-1404, 1978. 
APÊNDICE 
Nome Data

Por favor, avalie cada amostra usando a escala abaixo para descrever sua preferência. Em seguida, responda as questões abaixo.

Obrigado.

1. Desgostei muitíssimo

2. Desgostei muito

3. Desgostei regularmente

4. Desgostei ligeiramente

5. Indiferente

6. Gostei ligeiramente

7. Gostei regularmente

8. Gostei muito

9. Gostei muitíssimo

\begin{tabular}{|l|l|}
\hline AMOSTRA & VALOR \\
\hline & \\
\hline & \\
\hline & \\
\hline
\end{tabular}

Porque gostei

Porque desgostei

Freqüência de consumo: $(\quad)$ freqüentemente ( ) ocasionalmente ( ) nunca Em que locais compra este tipo de produto : ( ) supermercado ( ) peixaria ( ) outros, quais: 